\title{
The Anglo-Brabant Massif: persistent but enigmatic palaeo-relief at the heart of western Europe
}

Tim Pharaoh

British Geological Survey, Keyworth, Nottingham, NG12 5GG tcp@bgs.ac.uk

\begin{abstract}
The surface geology of central England and Belgium obscures a large 'basement' massif with a complex history and stronger crust and lithosphere than surrounding regions. The nucleus was forged by subduction-related magmatism at the Gondwana margin in Ediacaran time, and partitioning into platform and basin was already evident in Cambrian/earliest Ordovician time. The accretion of the Monian Composite Terrane during the Penobscotian deformation phase preceded late Tremadocian rifting, and Floian separation, of the Avalonia Terrane from the Gondwana margin. Late Ordovician magmatism in a belt from the Lake District to Belgium records subduction beneath Avalonia of part of the Tornquist Sea. This 'Western Pacific-style' oceanic basin closed in latest Ordovician time, uniting Avalonia and Baltica. Closure of the Iapetus Ocean in early Silurian time was soon followed by closure of the Rheic Ocean, recorded by subduction along the southern margin of the massif. The causes of late Caledonian deformation are poorly understood and controversial. Partitioned behaviour of the massif persisted into late Palaeozoic time, when both late Devonian and Carboniferous sequences show strong onlap, and during the Variscan Orogeny, when a wedge-shaped mountain foreland uplift was driven by orogenic indentation. Permian to Mesozoic sequences persistently exhibit onlap onto the massif.
\end{abstract}

Keywords:

Anglo-Brabant

Tectonics

Palaeo-relief

Avalonia

Caledonian

Variscan

\section{Introduction}

\subsection{Location}

The Anglo-Brabant Massif (ABM) is a long-lived component of the crust of central England and Belgium (Fig. 1). This paper reviews the evolution of the ABM from Neoproterozoic times, to the Present. The massif has strongly influenced palaeogeography and patterns of sedimentary deposition since Devonian time. Its origins are far older however, and to understand the behaviour of this distinctive and enigmatic tectonic element it is necessary to look both farther back, to crustal genesis in late Neoproterozoic time and a complex early Palaeozoic history, and deeper, into the lithosphere that lies beneath. In determining the distribution of Carboniferous coalfields, and hence the location of heavy industry and conurbations in the Industrial Revolution, it has continued to exert an influence into the Anthropocene. For more detailed reviews of specific periods in its history, and particularly of Belgian geology, the reader will be referred elsewhere.

Study of the massif is complicated by the following factors: 
- Very limited outcrop of pre-Mesozoic formations, restricted to possibly unrepresentative structural highs

- Old boreholes without geophysical logs provide a rather one-dimensional view

- Contacts between lithostratigraphic units are rarely seen, so it is difficult to establish stratigraphic thicknesses. This is a problem even in Belgium, where exposure of the massif is better in major river valleys

- Poor control from a very limited seismic reflection data

The ABM is located in the south-central Midland and East Anglian regions of England, extending eastward beneath the southern North Sea to Belgium (Fig. 1). Its boundaries are most easily defined using the extensional fault systems along its western (Permo-Triassic Worcester Graben), northern (Mississippian basins of the Pennine basin complex) and southern (Jurassic to early Cretaceous WealdWessex basin) boundaries. The Worcester Graben separates the ABM from the counterpart Welsh Massif, the two massifs exhibiting subtly different tectonic behaviour during post-Carboniferous time. All of these fault systems represent extensional reactivations of compressional faults formed in earlier tectonic regimes, respectively the Avalon, Caledonian and Variscan orogenies. In many places, the boundaries sharply defined by the extensional faults are obscured by transgressive sequences associated with post-rift thermal subsidence, respectively the late Triassic Mercia Mudstone Group, the late Carboniferous Pennine Coal Measures Supergroup and the late Cretaceous greensands. The marginal position of such post-extensional sequences naturally predisposed them to erosion in the next cycle of extension. Thus the subcrop patterns used to define the shape of the ABM vary considerably over time, as reflected in the numerous publications on this topic (e.g. see the various chapters in Cope et al., 1992). In the south, the crust of the massif is truncated by the thrust-front of the thin-skinned Variscan Variscide parautochthonous thrust nappes and must extend a significant distance farther south (Chadwick et al., 1983). In the east, the circumstances are simpler; the massif skirts the southern margin of the North Sea (Fig. 1), NE of the Strait of Dover, and is contiguous with the Brabant Massif of Belgium.

\subsection{Previous work and terminology}

In Belgium, the Brabant Massif was recognised beneath a thin Cenozoic cover as far back as the middle of the $19^{\text {th }} \mathrm{C}$ (Dumont, 1847). In the UK, the palaeogeographical maps of Leonard Wills (1948, 1951) contained many of the structural elements to be discussed here, because they integrated information derived from wartime strategic coal and oil exploration (e.g. Lees and Taitt, 1945), key boreholes (e.g. Bullard et al., 1940) and outcrop (Wills, 1948). Wills (1948, Fig. 4) and Wills (1951, Plate III Silurian) illustrates a triangular region labelled 'Shelf Sea' and 'Midland Kratogenic Block', corresponding to the Midland Platform or Microcraton of later authors. The 'Welsh Geosyncline' is shown to the NW of this region, and a conjectured geosynclinal trough to the NE. This hypothesis was developed further by Turner (1949) in his classic paper on the concealed Caledonides of northern and eastern England. In Plate IV (Caledonides), Wills (1951) recognised a little folded 'kratogenic' area and a syntaxis between 'SW and SE Caledonides'. By early Carboniferous time (Plate VI), terrestrial massifs are recognised in Wales and the Irish Sea ('St George's Land'), and the English Midlands ('Midland Barrier'), separated by a 'strait' in the south Midlands. It was already recognised that the Midland Barrier continued eastward into the Brabant Massif (Wills, 1951). . In late Namurian time, the terrestrial massifs had become amalgamated into the 'Wales-Brabant Massif' or island. By early Westphalian time, 'cuvettes' had developed in South Wales and Kent, along the southern margin of the Wales-Brabant Island, sourced from the 'Armorican Mountain Front' lying to the south. Careful study of clast composition in late Carboniferous sandstones and early Permian breccias revealed a complex 
history of fault reversal and reactivation (Wills, 1948), and Variscan inversion, long before seismic data were available. Wills (1951) referred to the Permo-Triassic manifestation of the ABM as the 'East Anglian Stable Massif' or 'Mercian Highlands'; and in Jurassic to Cretaceous time, as the 'AngloBelgian Island'. In generating these maps, Wills (1951) cited the work of numerous authors (W.J. Arkell, W.S. Bisat, F.W. Cope, A. Fowler, W. van der Gracht, D. Hill, R.G.S. Hudson, J.W. Jackson, P.E. Kent, W.B.R. King, A. Lamont, G.M. Lees, H.R. Lovely, L.R. Moore, F.J. North, D. Parkinson, D. Reynolds, D. Stamp, A.H. Taitt, A.E. Trueman, J.S. Turner, W.D. Ware and A. Wood), in particular authors of the Geological Survey Regional Handbooks. Neville George (1958) reviewed the early Carboniferous paleogeography of the British Isles, particularly focussing on St George's Land (Welsh Massif) and dealing with the Mercian Highlands more superficially. Perhaps surprisingly, neither Wills nor George directly cited each other's work, although George (e.g. 1970) was principal author of several of the regional guides on behalf of the Geological Survey. In the 1960's, a considerable improvement in palaeogeographal knowledge resulted from coal and hydrocarbon exploration, particularly in the East Midlands (Kent, 1966; 1968), principally by 'wildcat' drilling with very limited geophysical guidance, e.g. from gravity surveys. A comprehensiove memoir on the Brabant Massif by Legrand (1968) also dates from this time.

At about the same time, the seminal paper by Tuzo Wilson (1966) introduced the nascent science of global geodynamics to British historical geology by posing the question 'Did the Atlantic close and then reopen?'. Wilson's hypothesis was that a proto-Atlantic or Iapetus Ocean had existed in the vicinity of the modern Atlantic. The hypothesis was further developed in the paratectonic (southern British and Irish) Caledonides by Dewey (1969). The initial plate models focussed on the relationship between just two palaeocontinents, Laurentia and Avalonia, separated by the Iapetus Ocean. This is reflected in the palaeogeographic reconstructions presented by Anderton et al. (1979) showing a Midland Shelf Platform in early Cambrian and Wenlock time, and a Midland Platform for the remainder of early Palaeozoic time, forming part of an Anglo-Baltic Shelf in Cambrian to Silurian time. These authors recognised the Wales-Brabant Landmass in the Westphalian, and the Wales-Brabant Massif in Triassic and Jurassic time.

In the early 1980's, onshore hydrocarbon exploration generated an extensive coverage of 2D seismic reflection data, allowing comprehensive mapping of the Permian and Mesozoic basins of southern Britain (Whittaker et al., 1985). Mapping of the Carboniferous basins of central and northern Britain and other structural analyses (e.g. Besly, 1988) helped define the northern and western margin of the ABM in greater detail (Fraser et al., 1990; Fraser and Gawthorpe, 2003; Smith et al., 2005; Pharaoh et al., 2011; Butler, in press) but as the ABM was regarded as unprospective, the seismic surveys do not extend far into its interior. In the late 1980's, more sophisticated three plate models were developed for the Caledonides (Cocks and Fortey, 1982; Soper and Hutton, 1984; Pickering et al., 1988) soon supported by more detailed combined palaeomagnetic/faunal studies (Scotese and McKerrow, 1990; Torsvik et al., 1992; Cocks and Torsvik, 1992). These models required the separation of an Avalonia microcontinent from Baltica for much of Ordovician time. That part of Avalonia involved in the northern Applalachians of Canada, west of the Atlantic ocean basin, has been referred to as Western Avalonia; that part to the east, as Eastern Avalonia (e.g. Soper et al., 1987; Pickering et al., 1988). Debate continues as to whether or not these two parts of Avalonia were originally a contiguous ribbonlike microcontinent throughout the Caledonian orogenic cycle (e.g. Schofield et al., 2016); and whether crust in the southern North Sea belongs to Avalonia (see discussion in Pharaoh et al. $(1999 ; 2006)$ and Winchester et al. (2002). Landing (2013) has objected to the use of the term 'Midland Microcraton' (e.g. Turner, 1949; Soper et al., 1987; Pharaoh et al., 1987) as true cratonic behaviour is not exhibited. However, the Midland Platform certainly exhibits the behaviour of a massif resistant to the effects of the Caledonian Orogeny, as does its descendent, the ABM, during the Variscan and Alpine orogenies. In recent years, there has been a tendency for authors on Mesozoic and Cenozoic palaeogeography to 
refer to the massif as the London-Brabant Platform or High. To aid the reader, Fig. 2 summarises the terminology to be followed throughout this paper.

The mutual interest of British and Belgian geoscientists in exploring the composition and geological history of the ABM led to a series of workshops and scientific meetings. The proceedings of a meeting held in Brussels, in September 1989, were published in the Annales de la Société Géologique de Belgique (André et al., 1991). The proceedings of a second meeting, held at BGS in Keyworth in September 1992, were issued in a Special Issue of Geological Magazine Volume 130, published in September 1993 (Pharaoh et al., 1993b). A further milestone was the publication of the Geological Society's palaeogeographical atlas (Cope et al., 1992). Subsequently, studies of the ABM were facilitated by the various meetings of the Trans-European Suture Zone project of the ILP-sponsored EUROPROBE programme (Gee and Zeyen, 1996; Gee and Stephenson, 2006) and the PACE TMR Research Network, funded by the European Commission. The research collaborations established resulted in numerous further publications, including a special publication of the Geological Society (Winchester et al., 2002). One of the most significant results was the elucidation of the history of the Anglo-Brabant Deformation Belt (not to be confused with the ABM) which links the Caledonides of England and Belgium. Many of the same authors contributed to the Southern Permian Basin Atlas (SPBA) published by TNO and EAGE (Pharaoh et al., 2010; De Vos et al., 2010).

\section{Crustal and lithospheric structure}

The crustal structure of the ABM is less well known than that of surrounding regions, e.g. northern England and the region south of the Variscan Front. It was recognised from the exploration boreholes drilled in the pre-seismic era (1940s -1950s) that although coal-bearing basins are locally present on its northern margins, the massif is poorly prospective for oil and gas (Lees and Taitt, 1946; Falcon and Kent, 1960). Thus the dense networks of seismic reflection data acquired since 1970 in northern and southern England, which are so informative about the upper crustal and sedimentary basin structure in those areas (e.g. Whittaker, 1985; Kirby et al., 2000; Smith et al., 2005; Pharaoh et al., 2011) are largely absent over the massif. Significant coverage is only present in the NW (Staffordshire), the Worcester Graben and Oxfordshire Concealed Coalfield areas (Butler, in press). A small number of seismic reflection profiles, gathered by the British Geological Survey (Chadwick, 1985; Chadwick and Smith, 1988) and academic institutions (e.g. Maguire, 1987) provide limited insights to crustal structure. The massif is crossed by only one long lithospheric-scale seismic refraction profile (Lithospheric Seismic Profile in Britain, LISPB) acquired in 1974 (Bamford et al., 1976). The GAMMA segment ends in Buxton, just beyond the northern edge of the massif (Barton, 1992). The DELTA segment extends from North Wales to the Isle of Portland and an interpretation was published by Maguire et al. (2011). The segment crosses the massif in its west central part, intersecting shorter refraction profiles in the Bristol Channel area (Mechie and Brooks, 1984). Deep seismic reflection data, recorded to 12 or $15 \mathrm{~s}$ TwoWay Travel Time (TWTT) by the British Institutions Reflection Profiling Syndicate (BIRPS), based at Cambridge University, cover only the offshore area (Klemperer and Hobbs, 1991). These profiles are nevertheless useful in assessing the tectonic milieu of the massif. Deep seismic reflection data from northern France (Cazes and Toreilles, 1988) and Belgium (Bouckaert et al., 1988; Meissner and Bortfeld, 1990) demonstrate a gently southward-dipping Variscan detachment, with the crust of the ABM forming a tapering wedge in the footwall (Blundell, 1993). The latter extends some 60 to $100 \mathrm{~km}$ south of the Variscan Front, and its nature is confirmed by the continuity of the South Central England Magnetic Anomaly beneath the Variscan nappes (Beamish et al., 2016). Interpretations of crustal structure incorporating all of the available seismic data were integrated into maps of crustal structure by Chadwick et al. (1996), Ziegler and Dèzes (2006) and Kelly et al. (2007). Fig. 3 presents the results for Moho depth, Top crystalline basement and Thickness of crystalline crust from the analysis by 
Chadwick et al. (1996). The distinctive properties of the crust of the in the British part of the ABM compared to the surrounding areas, in particular the greater depth to the Moho compared to the surrounding regions, is visible in all three maps.

An integrated seismic velocity-gravity model for the LISP DELTA segment was presented by Maguire et al. (2011). The interpretation presented in Fig. 4a (from Maguire et al., op. cit.) is based on this model, but note that this diagram also incorporates features such as the Bala Fault, whose presence is inferred from other lines of evidence or otherwise hypothesised (Bristol Channel-Bray FZ). The Moho is recognised in all shot records. It is deepest (about $38 \mathrm{~km}$ ) beneath North Wales and the Welsh (early Palaeozoic) Basin, and rises southward to about $31 \mathrm{~km}$ at the Bristol Channel and $28 \mathrm{~km}$ at the Dorset coast. These values are comparable to those inferred by Chadwick et al. (1996), Ziegler and Dèzes (2001) and Kelly et al. (2007). The lower crust is a fairly constant $12 \mathrm{~km}$ thick beneath the massif, but beneath Wales may be heavily injected or underplated by sills associated either with the Ordovician magmatic history, or with the Cenozoic magmatic history of the Irish Sea Basin (Brodie and White, 1994; White et al., 2008). The combined middle-upper crust is thickest ( $25 \mathrm{~km})$ beneath the massif and thins south of the Variscan Front where it is overlain by deep Mesozoic sedimentary basins. Its velocity structure suggests a largely Neoproterozoic crystalline crust $\left(\mathrm{V}_{\mathrm{p}} 6.1\right.$ to $6.5 \mathrm{~km} \mathrm{~s}^{-1}$, density $2.90-3.15 \mathrm{Mg}$ $\left.\mathrm{m}^{-3}\right)$ overlain by slightly slower $\left(\mathrm{V}_{\mathrm{p}} 5.2\right.$ to $\left.6.0 \mathrm{~km} \mathrm{~s}^{-1}\right)$ and less dense $\left(2.66-2.72 \mathrm{Mg} \mathrm{m}^{-3}\right)$ low grade metamorphic (slate-schist) complexes. In Wales, the latter correspond to the 10-12 km deep Welsh Basin; in England, probably to low grade Avalonian metamorphic rocks with a cover of Old Red Sandstone up to $2.5 \mathrm{~km}$ thick. Modelling the lithostatic load suggests that the lithosphere is close to isostatic equilibrium at a depth of $60 \mathrm{~km}$ (the base of the model). Unfortunately the LISP data are not well located to answer the questions surrounding the permanency of the northern boundary of the ABM in the vicinity of The Wash. A new wide-angle seismic experiment is required there to resolve such matters. The ECORS (Cazes and Toreilles, 1988), BELCORP (Bouckaert et al., 1988) and DEKORP$1 \mathrm{~N}$ deep seismic reflection profiles show that the crust of the ABM is unreflective, and the Moho beneath unrecognisable (Blundell, 1993).

Deep seismic lines in the southern North Sea provide evidence on the crustal structure of the ABM in this region. A consistent structural pattern is evident in two lines from the BIRPS dataset (MOBIL-6 and -7), and the NOPEC/GECO line SNST 83-07 (England, 1995; SPBA, 2010), as summarised schematically in Fig. 4b. The lower crust of the ABM is poorly reflective, with the Moho inferred to lie at $9 \mathrm{~s}$ TWTT. The middle crust contains numerous inclined reflectors, mostly SW-dipping, and diffractions, indicating a complex structure (Reston, 1979: Reston and Blundell, 1987). Blundell (1993) and Lee et al. (1993) favoured genesis of these structures during Caledonian accretion. The lower crust of the southern North Sea is reflective down to a Moho at $12 \mathrm{~s}$ TWTT, SW of the deep reflector (1. on Fig. 4b). On the original seismic section the middle crust is non-reflective. The boundary between these two crustal types underlies the Dowsing-South Hewett Fault Zone (D-SHFZ). A prominent package of reflectors about $2.5 \mathrm{~s}$ thick (the X-reflector of Blundell et al., 1991; 'Mantle Event' of England, 1995) dips SW from 12 to $15 \mathrm{~s}$ TWTT to the bottom of the section (c. $15 \mathrm{~s}$ TWTT) over a horizontal distance of $40 \mathrm{~km}$. Assuming a mantle velocity of $8 \mathrm{~km} \mathrm{~s}^{-1}$, this corresponds to a dip of about $17^{\circ}$ to $\mathrm{SW}$, beneath the ABM. The parallel trend of these mantle structures and potential field anomalies (Lee et al., 1991), led Pharaoh et al. $(1993 ; 1995)$ to propose that the lithospheric structure recorded subduction of Tornquist oceanic crust beneath Avalonia. The latter was invoked as the cause of mid- to late Ordovician volcanic and plutonic magmatism within the ABM and northern England (see Section 5 below for further discussion of this topic). This concept was subsequently endorsed by Van Staal et al. (2008). Unfortunately the nature of the linkage of the Mantle Event to the co-located D-SHFZ is not well imaged by the deep seismic data, and no wide-angle data are presently available to constrain the depth of these structures. The unexposed basement of the southern North Sea and northern Germany between the DSHFZ and the Thor-Tornquist sutures is only proved by a few deep boreholes on the Mid-North Sea 
and Ringkøbing-Fyn highs (Frost et al., 1981; Berthelsen, 1998; Pharaoh et al., 1995; Lyngsie and Thybo, 2006). Some authors refer to this poorly known terrane as the 'Far Eastern Avalonia' (e.g. Unrug et al., 1999; Verniers et al., 2002; Winchester et al., 2002) although the term is not favoured by Torsvik and Cocks (2009). Potential field modelling (Williamson et al., 2002) suggests that the crust of this Southern North Sea Terrane (Franke, 1995; BGS, 1996) may include juvenile Caledonian-cycle accreted volcanic arc, marginal basins and granitic intrusions (Dutch offshore well A17-1) without ancient crustal inheritance (De Vos et al., 2010). This furtive terrane therefore appears to exhibit a juvenile, uncratonic character (Williamson et al., 2002), although a cratonic character is a requirement of some tectonic models (Sintubin and Everaerts, 2002; Debacker et al., 2005). The composition, structure and relationships of these crustal types are should be studied by future lithospheric-scale geophysical experiments in this region.

Much use has been made of geophysical potential field data (gravity and magnetic fields) in the structural interpretation of the concealed Caledonide basement in the upper crust of the ABM and adjacent northern England (e.g. Lee et al., 1991; 1993; Chacksfield et al., 1993; Pharaoh et al., 1995; Williamson et al., 2002). Only a brief summary will therefore be presented below. Magnetic and gravity potential field data acquired by BGS provide a complete regional coverage. The results of interpretation of these data are presented in various BGS memoirs, sub-surface memoirs and geophysical CDs. More recently, Beamish et al. (2016) extended the analysis to the middle and lower crust of the ABM by applying spectral decomposition techniques to study the Total Magnetic Intensity (TMI) of the reduced to pole magnetic data. Key features of the interpretation are the presence of a prominent linear magnetic high in the upper crust extending from the Lake District to East Anglia, labelled 'FINMA' (FurnessIngleborough-Norfolk Magnetic Anomaly) in Fig. 5a. This has been interpreted as due to the presence of metamorphic rocks (Wills, 1978), magnetite-rich Cambrian strata (Lee et al., 1993) or a Caledonian magmatic arc (Pharaoh et al., 1993a; 1995; Pharaoh, 1999) in the upper crust. A second, more inboard but discontinuous anomaly, labelled 'DSIMA' (Derby-St Ives Magnetic Anomaly) in Fig. 5a, is certainly associated with a belt of dioritic intrusive bodies of presumed Ordovician age (Allsop, 1987; Cornwell and Walker, 1989; Pharaoh et al., 1993a). Two further, more compact magnetic anomalies, 'BMA' (Birmingham Magnetic Anomaly) and 'CEMA' (South Central England Magnetic Anomaly) have been attributed to the presence of shallow Neoproterozoic (Charnian) metavolcanic rocks (Lee et al., 1990; Busby et al., 1993). The TMI magnetic data reveal the deep edges of the ABM, and its extension at depth into Wales, eastern England and south of the Variscan Front (Beamish et al. 2016; Figure 8c). The high magnetic susceptibility of the Charnwood Terrane (and CEMA) suggest that the silicic volcanic and volcaniclastic rocks inferred in the upper crust are likely replaced by more intermediate, magnetite-rich plutonic magmatic rocks at greater depth The gravity anomaly map (Fig. $5 b$ ) is dominated by the effect of sedimentary basins of Carboniferous age to north of the ABM, PermoTriassic age to the west (Worcester Graben) and Mesozoic age to the south (Weald-Wessex basins). Within the ABM, strong negative gravity anomalies have been attributed to the presence of granite intrusions in the vicinity of The Wash (Chroston et al., 1987), comparable in magnitude to those at Market Weighton (Bott et al., 1978) and on the Eastern England Shelf (Donato and Megson, 1990). Geophysical potential field data in Belgium, which are not displayed here, have been reviewed by Chacksfield (1993) and Mansy et al. (1999). The presence of a concealed granitic body on the southern margin of the massif in Belgium was postulated by De Vos (1997), although Mansy et al. (1999) and Sintubin and Everaerts (2002) prefer to interpret this as cratonic crust, the continuation of the Midlands Platform.

Zhu et al. (2015) present a shear wave model $\left(\mathrm{EU}_{60}\right)$ of the crust and mantle down to $800 \mathrm{~km}$ depth based on tomographic inversion of seismograph records. In such models, fast anomalies (positive) are found beneath major cratonic areas, e.g. the ancient crust of the Baltica continent, in Norway and Sweden and northern Poland, or associated with inferred subduction slabs; slow (negative) anomalies 
are associated with zones of high heat flow/partial melt, such as the Iceland-Faeroe Ridge, Rhine Graben, Bohemian Massif and Pannotian Basin (Zhu et al., 2012). Fig. 6 presents four depth slices through this model at $60 \mathrm{~km}, 120 \mathrm{~km}, 180 \mathrm{~km}$ and $240 \mathrm{~km}$ depth. The mantle beneath the ABM shows fast shear wave anomalies through most of the depth range depicted. The ABM is revealed as a discrete feature, comparable in scale to, but independent from, similar fast shear wave anomalies in the Paris Basin, but closely associated with NW-SE trending linear fast anomalies in the southern and central North Sea. The latter are interpreted to represent subduction slab(s), relict from the closure of the Tornquist Sea between Avalonia and Baltica in Ordovician time, as proposed by Zhu et al. (2012). The cause of the fast anomaly beneath the ABM is less easily explained, but may be inherited from the time of crustal formation in Neoproterozoic time. It is also apparent that in contrast to the ABM, the Welsh Massif is underlain by slow mantle anomalies to $60 \mathrm{~km}$ depth, perhaps (but not necessarily) related to the lower crustal/mantle underplating postulated by Brodie and White (1994) and White et al. (2008).

Compared to surrounding crustal regions, the ABM (and its continuation to south of the Variscan Front) is significantly less affected by natural seismicity (Chadwick and Pharaoh, 1996). The only exception concerns the cluster of historical and imprecisely located seismic events to north of the Dover Strait. Both the Carboniferous basins located on the Caledonian crust of northern Britain, and the Ediacaran crust in parts of the Welsh Massif and Irish Sea Landmass, display higher levels of seismic activity (Chadwick and Pharaoh, 1996). This characteristic also suggests that the crust of the ABM may be stronger and distinct from that of the surrounding regions.

To summarise, the crust of the ABM is slightly thicker and stronger, and underlain by a lithosphere with positive shear-wave anomalies, compared to the surrounding lithosphere. The cause of the 'cratonic' behaviour remains enigmatic, but the long history of the massif suggests that these characteristics were inherited early on, probably during Neoproterozoic crustal genesis, during subduction magmatism and accretion to the crust of Gondwana (Chadwick et al., 1989; Blundell, 1993).

\section{Precambrian evolution}

\subsection{Introduction}

The Neoproterozoic basement of the ABM has been divided into a number of lithotectonic terranes (Pharaoh et al., 1987b; Pharaoh and Carney, 2000). Most of the central part of the ABM is underlain by Ediacaran intermediate and felsic volcaniclastic rocks, comprising the Charnwood Terrane (Pharaoh and Carney, 2000). These crop out in Charnwood Forest, where they are located in a crustal duplex of probable Caledonian age at the NE margin of the Midlands Microcraton (Fig. 7); and in the Nuneaton area, where the Caldecote Volcanic Formation contains all the key Charnian components (Carney and Pharaoh, 1993; Bridge et al., 1998). The geochemical affinities of basement rocks proven by deep boreholes at Kempsey, in the Worcester Graben, and Withycombe Farm, in Oxfordshire (Fig. 7), also lie with the Charnian magma type (Pharaoh and Gibbons, 1994; Pharaoh and Carney, 2000). The eastern part of the ABM is underlain by the Fenland Terrane (Pharaoh and Carney, 2000) which comprises a basement of silicic ash-flow tuffs proved in just three boreholes (Glinton, Orton and Oxendon Hall). These show lithological similarity to the Padarn Tuff of the Cymru Terrane, the inferred basement to the early Palaeozoic Welsh Basin (Pharaoh and Carney, 2000). The Glinton occurrence is associated with a major thrust zone within the concealed Caledonides (Pharaoh, in Chadwick and Evans, 2005); the other occurrences lie close to the inferred eastern boundary of the Charnwood Terrane (Fig. 7). From the Malvern Hills westward through the Welsh Borderland, the eastern part of the Welsh Massif is inferred to be underlain by Ediacaran basement of the Wrekin Terrane (Pharaoh and Carney, 2000). A suture of late Ediacaran age is inferred to separate the Charnwood and Wrekin terranes along the eastern edge of the Malvern Hills (Pharaoh et al., 1987b). Reactivation of this Malvern Line has 
controlled extension and inversion along the western edge of the Worcester Graben throughout Palaeozoic and Mesozoic time (Barclay et al., 1997). The above terranes were finally amalgamated into an Avalon Composite Terrane at the Amazonian margin of Gondwana, perhaps a little farther west than indicated on the reconstruction in Fig. 8a, during the Avalon Orogeny in latest Neoproterozoic time. Precambrian rocks are not exposed within the Brabant Massif, but the presence of underlying Neoproterozoic and older crust is inferred from its contribution to the petrogenesis of early Palaeozoic volcanic rocks and detritus in early Palaeozoic sediments (André, 1991; Verniers et al., 2002).

\subsection{Early calc-alkaline magmatism and metamorphism}

The oldest known magmatic rocks in England belong to the Stanner-Hanter Complex, a bimodal gabbro-granite complex, located on the Church Stretton Fault Zone, straddling the border with Wales (Fig. 7). Concordant zircons from a granophyric granite component have yielded a Weighted Mean U$\mathrm{Pb}$ age of $710.8 \pm 1.5 \mathrm{Ma}$, interpreted as the crystallisation age of the complex (Schofield et al., 2010). Slightly younger $\mathrm{U}-\mathrm{Pb}$ ages have been obtained from the Malverns Complex, involved in a transpressional flower structure of Variscan age on the western side of the Worcester Graben (Fig. 7). Granitoid components of the calc-alkaline intrusive complex have been reliably dated to $677 \pm 2 \mathrm{Ma}$ (Tucker and Pharaoh, 1991) using the U-Pb zircon method. A volumetrically smaller component of paragneiss, interpreted as a host to the plutonic rocks, yields zircons with core $\mathrm{U}-\mathrm{Pb}$ ages as old as $1965 \pm 7 \mathrm{Ma}$, with significant concentrations at 1.6 to $1.5 \mathrm{Ga}$, and 1.3 to $1.0 \mathrm{Ga}$ (Strachan et al., 2007). The complex was subjected to metamorphism at greenschist and amphibolite facies between 670 and $650 \mathrm{Ma}$ (Strachan et al., 1996). The presence of a Mesoproterozoic zircon inheritance in both StannerHanter and Malvern complexes (Tucker and Pharaoh, 1991; Schofield et al., 2010; Strachan et al., 2007), supported by Sm-Nd model ages, favours an origin on the margin of Gondwana closest to the Amazon Craton and Mexico (Nance and Murphy, 1994; Murphy et al., 2000; Samson et al., 2005; Strachan et al., 2007; Nance et al., 2008) rather than the West African Craton, where such rocks are absent. Detrital zircon suites from early Cambrian quartzites also support this conclusion (Murphy et al., 2004).

The Fenland Terrane is known from only 3 borehole provings as described above, and is believed to underlie the eastern part of the ABM (Fig. 7). Silicic ash-flow tuffs, petrographically and geochemically comparable to the Padarn Tuff of north Wales (Dearnley, 1966; Pharaoh and Carney, 2000) have yielded U-Pb zircon ages of $612 \pm 2 \mathrm{Ma}$ and $616 \pm 6 \mathrm{Ma}$ (Noble et al., 1993) identical within the errors to the age (614 $\pm 2 \mathrm{Ma}$ ) of the Padarn Tuff (Tucker and Pharaoh, 1991). These ages are older than those obtained from the Charnwood Terrane (see below), and the strong lithological, geochemical contrast with the latter led Pharaoh and Carney (2000) to recognise a separate, Fenland Terrane. The boundary between the two terranes is not exposed and its precise course uncertain. It is considered to lie beyond the NE limit of Charnian outcrop/subcrop, and to run roughly parallel to the NE boundary of the Midland Microcraton (Fig. 7). The boundary depiocted on Fig. 7 is guided by the geophysical potential field data.

\subsection{Late rifting and marginal basin development}

The Charnian Supergroup comprises a thick (> $3 \mathrm{~km}$ ) pile of deep-water volcaniclastic strata with minor synvolcanic intrusive bodies and a late plutonic suite of diorites. The volcaniclastic strata host Ediacaran fossil assemblages, dated by the U-Pb zircon method at 569.1 $\pm 0.9 \mathrm{Ma}$ (Noble et al., 2015), comparable to those found in Newfoundland and elsewhere. The youngest Charnian strata were deposited at c. $559 \mathrm{Ma}$ (Compston et al., 2002), but also contain an inherited detrital population at c. $604 \mathrm{Ma}$ (Noble et al., 2015). The latter age is slightly younger than that of silicic tuffs (e.g. the Padarn 
and Glinton tuffs) in the Cymru and Fenland terranes, and may have been reworked from them. It is also identical within the errors to the age of $603 \pm 2 \mathrm{Ma}$ obtained for a fraction of euhedral prismatic zircons separated from granophyric diorite of the South Charnwood Diorite Suite intruding the Charnian Supergroup at Nuneaton (Tucker and Pharaoh, 1991). This zircon fraction is now interpreted as xenocrystic, reworked from a basement type not exposed in the Charnwood Terrane, or inherited from such a source in the Fenland Terrane via a cycle of sedimentary reworking. Further indications of older inheritance come from volcaniclastic sandstones deeper in the sequence, yielding zircon cores dated at 611.3 $\pm 1.1 \mathrm{Ma}$, as well as Mesoproterozoic ages (Noble et al., 2015). The Brand Group, formerly included in the Charnian Supergroup (Moseley and Ford, 1985) is now excluded because it contains the trace fossil Teichichnus (Bland and Goldring, 1995) indicating an early Cambrian age and is likely unconformable upon the Charnian Supergroup (McIlroy et al., 1998). Other exposed components of the Wrekin Terrane include silicic, intermediate and basic tuffs and lavas of the Uriconian Group, dated at $566 \pm 2 \mathrm{Ma}$; and the sub-volcanic Ercall Granophyre, dated at $560 \pm 1 \mathrm{Ma}$ (Tucker and Pharaoh, 1991). The Longmyndian Supergroup is a $6500 \mathrm{~m}$ thick sequence of lithic sandstones and conglomerates, with a provenance including Uriconian volcanic rocks (Pauley, 1990). Thin ash (metabentonite) and tuff horizons, which have yielded SHRIMP U-Pb ages of $566 \pm 2.9 \mathrm{Ma}$ and $555.9 \pm 3.5 \mathrm{Ma}$ (Compston et al., 2002), reflect the waning phase of Uriconian magmatism (Greig et al., 1968). The severe inversion and sinistral transpression (Strachan, 2012) affecting the Longmyndian basin appears to have taken place rather abruptly, over a period of perhaps 5-10 Ma. Lavas of the Warren House Formation form a small $\left(<1 \mathrm{~km}^{2}\right)$ outcrop on the eastern flank of the Malvern Hills (Penn and French, 1971; Thorpe, 1974). Altered basalt and basaltic andesite lavas, exhibiting small pillow structures occur with minor amounts of rhyolitic tuff, which have yielded concordant U-Pb zircon ages of $566 \pm 2 \mathrm{Ma}$ (Tucker and Pharaoh, 1991). Although identical in age to the Uriconian lavas, the geochemical composition of basaltic components differs. The Uriconian basalts have a significant subduction-related component; the Warren House basalts have a much smaller subduction component and are chemically most similar to primitive marginal basin basalts (Thorpe, 1974; Pharaoh et al., 1987b).

\subsection{The Avalon Orogeny}

The small marginal basins created in the period 570-555 Ma were closed and inverted by the shortlived Avalon Orogeny, the terminal phase of Ediacaran crustal genesis and accretion on the Amazonian margin of Gondwana, at about 550-542 Ma.This tectono-magmatic event is part of the widespread 'PanAfrican' event, which consolidated juvenile crustal additions to Gondwana in late Neoproterozoic time, and which might therefore be more appropriately named the 'Pan-Gondwanan Orogeny'. The orogenic event is comparable with, and contemporaneous to the Cadomian Orogeny (D'Lemos et al., 1990), although use of the latter term is generally restricted to the north-west African margin of Gondwana (and terranes derived there). The term 'Avalonian Orogeny' is widely used, but generally poorly defined (e.g. Keppie and Murphy, 1988; O'Brien et al., 1990) and ripe for confusion with the 'Avalonia Terrane', which came into existence some $60 \mathrm{Ma}$ later. Here the term Avalon Orogeny is preferred, but confusion will probably remain until a completely new term is introduced.

Despite their insignificant outcrop area, the Warren House Formation lavas provide important evidence for the tectonic history of the suture between the Wrekin Terrane, and the Charnwood Terrane, forming the exposed basement of the ABM to east of the Malverns. The most obvious field expression of 'soft collision' during the Avalonian Orogeny is the isoclinal folding and cleavage development in the Longmyndian Supergroup (James, 1956; Toghill and Schell, 1984). Longmyndian slates have yielded whole rock ${ }^{40} \mathrm{Ar} /{ }^{39} \mathrm{Ar}$ total gas and fusion spot ages in the range 547-542.5 Ma, with retrogression down to $500 \mathrm{Ma}$ (M. Pringle, pers. comm. 1998). Metamorphism of the more massive volcanic sequences is less obvious, but probably reflected in strong alteration and silicification. 
Consolidation of the Neoproterozoic terranes described above into the Avalon Composite Terrane (ACT) or Avalon Superterrane (Gibbons, 1990; Pharaoh and Carney, 2000) at the Amazonian margin of Gondwana (Nance and Murphy, 1994; Murphy et al., 2000, 2004; Strachan, 2012) was completed shortly before the Precambrian-Cambrian boundary at 541 Ma.

\subsection{Comparison with the Avalon Peninsula and other Ediacaran sequences in the North Atlantic region}

Anglesey and the Lŷn Peninsula, lying north of the Menai Strait Fault System (MSFS), are occupied by the Monian Composite Terrane (MCT), an accretionary complex comprising imbricated lenses of Neoproterozoic (the Coedana, Aethwy terranes of McIlroy and Horak, 2006) and the Cambrian Monian Supergroup (South Stack, New Harbour and Gwna groups), bounded by ductile shear zones of Ordovician age (Gibbons, 1990; Gibbons and Horak, 1996). The Bwlch Gwyn Tuff of Anglesey is lithologically comparable to the Padarn Tuff, and is caught up in one of these zones. The Coedana Granite has yielded a U-Pb age of $614 \pm 4 \mathrm{Ma}$ (Tucker and Pharaoh, 1991), identical within errors to the age of the Padarn Tuff and the Glinton-Orton suite of the ABM (Noble et al., 1993). The Monian Supergroup was formerly thought to be of Precambrian age (Shackleton, 1975) but dating of detrital zircons from the South Stack Group indicates that the entire supergroup is no older than mid-Cambrian (see next section). The Monian rocks are unconformably overlain by cleaved strata of Arenig age. The accretion of the composite terrane to the margin of Gondwana, probably occurred in late Tremadocian time (see below). In SE Ireland, the Rosslare Complex forms the along strike continuation of the MCT, comprising elements of similar age. Schofield et al. (2016) recognise two major divisions within the Ediacaran terranes of southern Britain: The Monian Composite Terrane (and correlative Fenland Terrane) with abundant magmatism at about $615 \mathrm{Ma}$; and the more diverse assemblage represented by the Cymru, Wrekin and Charnwood terranes, with magmatism at around 580-560 Ma. Both have an ensialic setting and zircon provenance with greater affinity to West Gondwana and the terrane Ganderia, than to the magmatic rocks of West Avalonia.

In Newfoundland, the Avalon Zone (O'Brien et al., 1993) extends east from the Dover Fault to the Grand Banks offshore. It comprises a fault-bounded collage of arc-related Neoproterozoic volcanosedimentary belts (O’Brien et al., 1996; Murphy et al., 1999; Pollock et al., 2009). Rift-related successions (Burin Group) as old as $760 \mathrm{Ma}$ are known, but phases of arc-volcanism occurred at c. 730 $\mathrm{Ma}$ and $675 \mathrm{Ma}$. The main phase of volcanism occurred at 635 to $570 \mathrm{Ma}$. A largely volcanic sequence $>8 \mathrm{~km}$ thick yields precise zircon U-Pb ages in the range 620-605 Ma (O'Brien et al., 1989; Mills, 2016), and is unconformably overlain by the $50 \mathrm{~m}$ thick Gaskiers-Trinity glaciomarine diamictite, dated at about $579 \mathrm{Ma}$ (Pu et al., 2016). In the intervening gap of about $25 \mathrm{Ma}$, the volcanics were deformed into an imbricate fold-thrust belt and extensionally faulted before deposition of the diamictite. This episode approximately correlates with the change from subduction arc to extension, recognised throughout the Avalon Peninsula (e.g. Nance and Murphy, 1996; Thompson et al., 2014). The Ediacaran biota of the c. 565 Ma Mistaken Point Formation (Benus, 1988) is virtually identical to that of the Charnian Supergroup (Ford, 1958; Boynton, 1978; Moseley and Ford, 1985; Wilby, this volume), and the hosting strata (volcaniclastic and lithic turbidites) are so similar they could have been deposited in neighbouring parts of the same sedimentary basin. As the base of the Charnian sequence is not exposed, and a Gaskiers equivalent horizon has not been reached, it is conceivable that the Charnian sequence could also be underlain by a silicicic volcanic sequence many (>8?) kms thick. Further northwarddirected thrusting and prehnite-pumpellyite to greenschist facies metamorphism (Papezik, 1974) post$565 \mathrm{Ma}$ is attributed to the Avalon Orogeny (Anderton et al., 1975), and preceded deposition of the Random Group (Cambrian to Tremadocian) shaly platform strata (Van Staal and Barr, 2012).

Detrital zircon ages suggest the Gander Group of Newfoundland is underlain by a basement of Ediacaran to early Cambrian magmatic arc rocks (Dunning and O'Brien, 1989; O'Brien et al., 1991; 
Van Staal and Barr, 2012). In New Hampshire and Massachusetts, e.g. the Bronson Hill Arc (Tucker and Robinson, 1990) and in New Brunswick and Newfoundland (Van Staal et al. 1996; 1998), zircon $\mathrm{U}-\mathrm{Pb}$ ages of around $613 \mathrm{Ma}$ are typical of the Ganderian basement (O'Brien et al., 1996; Van Staal et al., 1996), and are comparable to those obtained from the Coedana Granite and the Padarn Tuff (Tucker and Pharaoh, 1991; Schofield et al., 2016).

\section{Cambrian-Tremadocian platform and basinal sequences}

\subsection{Introduction}

A short period of erosion of the juvenile Neoproterozoic crust preceded a significant marine transgression onto the margin of Gondwana (Brasier, 1980), generally presumed to be by the Iapetus Ocean, which began opening in latest Neoproterozoic time, breaking up the supercontinent of RodiniaPannotia (Dalziel, 1991; 1997). Most authors favour separation of Avalonia as a microcontinent from Gondwana in late Early Ordovician (Floian) time (Scotese and McKerrow, 1990; McKerrow et al., 1992; Prigmore et al., 1997; Fortey and Cocks, 2003; Cocks and Torsvik, 2006; Woodcock, 2012a) although other authors have argued for late Cambrian (Van Staal et al., 2012) or even Ediacaran departure (e.g. Pillola, 1993; Landing, 1996; 2005; Landing et al., 2013). For example, Landing (op. cit.) emphasises the lithostratigraphic and biotic distinctiveness of Avalonia in the early Cambrian, a persistently cool-water, higher latitude microcontinent in contrast to the carbonate- and evaporitebearing, tropical and low latitude sequences in African Gondwana e.g. northern France and Iberia. Cocks and Torsvik (2009) argue strongly for a Gondwanan margin in Cambrian time with a strong latitudinal control of biostratigraphic associations and rifting of Avalonia from Gondwana only in late Early Ordovician time (Fig. 8). Woodcock (1991) recognised that the stratigraphic megasequences identified previously in Wales (Woodcock, 1990) could also be recognised in the Brabant Massif (Fig. 9). The nomenclature applied by Verniers et al. (2002) is therefore applied to the same megasequences in the western part of the ABM. The reader is referred to this latter paper for a more detailed review of the early Palaeozoic evolution of the crust of the ABM, particularly in Belgium, than can be accomplished here.

\subsection{Platformal sequences of Megasequence 1}

That part of the Avalon Composite Terrane (Pharaoh and Carney, 2000) comprising the Wrekin and Charnwood terranes formed a shallow marine platform in early Cambrian time, referred to as the Midland Platform (e.g. Cope et al., 1992; Woodcock, 2012a). This platform received an overstepping cover sequence comprising thin $(30-60 \mathrm{~m})$ basal shoreface orthoquartzitic facies e.g. the Wrekin and Malvern quartzites (Fig. 9), passing up into 200-300 m thick nearshore clastics (Comley, Hollybush and Hartshill sandstone formations) (Brasier et al., 1978; Rushton, 2011; Woodcock, 2012a). These sequences locally contain 'small shelly fossil' horizons comprising hyoliths, primitive molluscs etc (Brasier, 1984) which can be precisely correlated with strata of the upper Terreneuvian Series in the Avalon Peninsula of SE Newfoundland (Brasier et al., 1992). The same assemblage is found overlying lavas with Charnian magmatic affinity in the Withycombe Farm Borehole (Rushton and Molyneux, 1990; Pharaoh and Gibbons, 1994; Rushton, 2012). The oldest Cambrian (Fortunian) stage is missing, so a time gap of perhaps $15 \mathrm{Ma}$ exists since the start of the period at $541 \mathrm{Ma}$. Overlying strata are mid to late Cambrian (International epochs 2, 3 and Furongian) mudstones with subordinate sandstones and/or limestones, deposited below wave-base on a gently subsiding shelf. A number of significant hiatuses and hardgrounds are present (Rushton, 1974; Landing, 1996). The Brand Group of Charnwood 
Forest, formerly regarded as part of the Charnian Supergroup, is now referred to the Cambrian due to the occurrence of Cambrian-style trace fossils (McIlroy et al., 1998) including Teichichnus rectus (Bland and Goldring, 1995). The Swithland Formation comprises a sequence of lithic sandstones and mudstones, rather different in aspect to the other platformal successions, and presumably, deposited in deeper water. Numerous boreholes drilled for exploration of the concealed Warwickshire Coalfield (Worssam and Old et al., 1988; Bridge et al., 1998) terminate in Cambrian or earliest Ordovician (Tremadocian) strata. Older boreholes are listed in Cowie et al. (1972, Table 2). For clarity, not all are labelled in Fig. 10, which gives a general impression of their distribution. Most cores are of Furongian age (Rushton, 2011). The presence of dips up to $60^{\circ}$ in many of these boreholes demonstrates that the sequence is strongly folded across a wide area. In quarries near Nuneaton, the upper Cambrian strata display chevron folds (Carney et al., 1992; Bridge et al., 1998) cross-cut by dykes of the Midlands Minor Intrusive Suite (see later section), indicating pre-Silurian deformation. The boreholes at Ticknall, proving Upper Cambrian (Carney and Ambrose, 2017), and Crown Hills (Le Bas, 1968) and Wyboston (Stubblefield, 1967), proving Tremadocian strata, lie just beyond the northern boundary of the microcraton, as defined in Fig. 10. The platform extended south of the Variscan Front (as shown by the Shrewton borehole, Fig. 10), the front being a tectonic boundary of later Palaeozoic age subsequently superimposed on the ABM.

Smith and Rushton (1993) recognised that the Worcester Graben, presently filled with PermoTriassic strata, had an early Palaeozoic antecedent, referred to by them as the 'Tremadoc Worcester Graben', and here as the 'Worcester Proto-graben'. This major N-S trending structure probably initiated as an 'aulacogen' (Hoffman et al., 1973), possibly the 'failed arm' of a continental margin rift prior to opening of the Rheic Ocean. The increasing width of the proto-graben to the south indicates that the margin lay in that direction. reflected in thickening of the Tremadocian strata (to $>2 \mathrm{~km}$ ) at crop in the Tortworth Inlier, and in boreholes at Cooles Farm, and at Yarnbury and Shrewton south of the Variscan Front (Smith and Rushton, 1993). Subsidence of the graben followed reactivation of the Neoproterozoic Malvern Line suture in extension. It is interpreted to anticipate the break-off of a microcontinent from the peri-Gondwana margin, subsequently known as Avalonia. Post-Tremadocian Ordovician strata are not preserved on the platform, so its subsequent subsidence history is not known, unlike the basin (Prigmore et al., 1997). Subsequently, a Silurian shelf sequence was deposited. Between the Malvern Line and the Welsh Borderland Fault System (WBFS), Silurian strata generally directly overlie a Precambrian basement, so that Cambrian-Tremadocian strata are absent (e.g. in the Heath Farm and Collington boreholes), but Upper Cambrian-Tremadocian strata are present in the Fownhope Borehole (Barron and Molyneux, 1992a, b) within the Woolhope Basin. East of the proto-graben, CambrianTremadocian strata are preserved beneath a patchy Silurian platform cover across a wide area of the south Midlands subsurface (Fig. 10), possibly reflecting asymmetry of the graben. Subsequently, the proto-graben received the attenuated late Palaeozoic sequence typical of a location within the ABM: thin onlapping sequences of upper Devonian, late Coal Measures and Warwickshire Group strata. The proto-graben apparently escaped inversion in the Acadian phase, but during late Carboniferous (?Stephanian time), it was inverted as a positive flower structure/horst (Chadwick and Smith, 1988), with thrusting westwards at the Malvern Line and eastwards into the Oxford Basin (Peace and Besly, 1997). Neoproterozoic volcaniclastic rocks were unroofed in the northern, most squeezed part of the proto-graben (Kempsey borehole, Fig. 10).

\subsection{Basinal sequences of Megasequence 1}

Several deep boreholes in Northamptonshire, Huntingdonshire, Lincolnshire and northern Norfolk encountered moderately deformed, very hard unfossiliferous coarse clastics and phyllitic mudstones (Fig. 10), lying within the late Caledonian fold-thrust belt in the eastern part of the ABM. Cowie et al. 
(1972), following Kent (1967), gave details for Bardney 1, Eakring 146 (Duke's Wood), Nocton 1 and Stixwould 1 boreholes, accepting that Cambrian rocks might be represented. Brasier et al. (1992) concurred with this analysis. Since that time, several other exploration boreholes have encountered such strata. Further details of these are presented in Pharaoh and Gibbons (1994); Table 5 and Pharaoh et al. (2011). The following account is based on the examination of core, borehole records and geophysical log data in the National Geological Repository by the author. In addition to Nocton 1 mentioned above, pale green, brown and grey quartzites were proved by Galley Hill (NCB), Gas Huntingdon 1, South Creake 1, Spalding 1 (Texaco) and Wisbech 1 (Texaco) boreholes. Green chlorite-rich phyllites were proved by Foston 1 (D'Arcy), Grove 3 (BP), Sibsey 1 (Ball and Collins) and Welton 1 (BP) boreholes. The age of the strong tectonic foliation in these greenschist facies metapelites is unknown, and the hypothesis of Acadian (Pharaoh et al., 1987) or Brabantian (Carney et al., 2008; Woodcock, 2012a) age requires testing. The widespread occurrence of these chloritic metasedimentary rocks in the preCarboniferous subcrop is reflected in the presence of chlorite-rich basal Tournaisian strata (up to $50 \mathrm{~m}$ in the Grove 3 and Welton 1 boreholes in the East Midlands, and Wessenden 1 and Holme Chapel 1 in northern England (borehole completion reports). The core at Stixwould 1 is a feldspathic sandstone, to which basement beds in Hunstanton 1 (uncored) may be similar. Bardney 1, Gas Stamford 2 (Nassington), Gas Stamford 10 (Thornhaugh) and Wittering 1 proved dark grey-green massively bedded greywacke sandstones containing numerous intra-formational clasts of shale and siltstone. They appear more massive and less mud-rich than greywackes of probable Silurian age, in the Anglian Basin (Woodcock and Pharaoh, 1993). The undated provings occupy a NW-SE trending belt on Fig. 10, suggesting a tectonostratigraphic association, and were allocated to an 'Undated quartzite-phyllite association' by Pharaoh et al. (2011). They appear to represent deep water deposits perhaps formed on the continental margin/rise of Avalonia.

In Belgium, the earliest megasequence recognised in the Welsh Basin by Woodcock (1990) is also recognised in the Brabant Massif, and in the Condroz Inlier (Fig. 9), its continuation within the Variscide parautochthon (Woodcock, 1991; Vanguestaine, 1992; Herbosch and Verniers, 2012; Verniers et al., 2002). The base of the sequence is not exposed but the presence of a Neoproterozoic basement is inferred (André, 1991). Cambrian strata are deployed in a complex anticlinorial structure (De Vos et al., 1993) forming the core of the Brabant Massif (Fig. 10). The megasequence begins with the $1.5 \mathrm{~km}$ thick Blanmont Formation (base not seen), comprising massive tourmaline-bearing sandstone and quartzite with slate intercalations, for which a rift environment is inferred (Debacker and Herbosch, 2011). The overlying Tubize Group, >2 km thick, comprises green slate and siltstone interpreted as basinal strata. High magnetite content gives a strong aeromagnetic signature (Chacksfield et al., 1993; Sintubin and Everaerts, 2002). Purple and green slates of the Oisquercq Formation are c. $1.5 \mathrm{~km}$ thick. The above formations are dated (using Oldhamia and acritarchs) from the base of Cambrian Stage 3 to upper Stage 5 (c. 520 Ma to $506 \mathrm{Ma}$ ) (Vanguestaine, 1992; Herbosch and Verniers, 2011). The overlying Jodoigne and Mousty formations (Fig. 9), >4 km thick, are a sequence of turbiditic sandstones, black quartzites and graphitic slates deposited in anoxic deep-sea environments (Debacker and Herbosch, 2011). Mn-enrichment indicates an episodic volcanic exhalative source. The Mousty Formation grades up into the grey Chevlipont Formation, both formations containing lower Tremadocian graptolites (Vanguestaine, 1992). The new thickness estimate (>9 km) for the megasequence is much greater than previous estimates of $>3.7 \mathrm{~km}$ (e.g. Verniers et al., 2002) and is comparable to that estimated for Cambrian sequences in the Meguma Terrane (of Nova Scotia) and the Welsh Basin (Waldron et al., 2011). Detrital zircons from Megasequence 1 demonstrate that it is a typical peri-Gondwanan terrane with major Pan-African (Neoproterozoic), some Mesoproterozoic, Palaeoproterozoic and Archaean (mixed West African and Amazonian) sources (Linnemann et al., 2012). 


\subsection{Comparison with Cambrian-Tremadocian sequences elsewhere in the Caledonides}

The Welsh early Palaeozoic Basin occupies the Welsh Massif between the WBFS and Menai Strait (MSFS) Fault System. Cambrian-Tremadocian strata are assigned to the Dyfed Megasequence (Woodcock, 1990), correlated with Megasequence 1 in the ABM (Woodcock, 1991; Verniers et al., 2002). In early Cambrian time, initial shallow-water (delta/pro-delta) deposition soon gave way to deep marine and turbidite deposition in the rapidly subsiding basin (Woodcock, 2012b), so that $>5000 \mathrm{~m}$ of Cambrian-Tremadocian strata were deposited, much more than on the platform (usually $<2000 \mathrm{~m}$ ). This is despite the presence of major discontinuities in the basinal succession (Fig. 9). In the south, the SW Dyfed succession, deposited at offshore shelf depths, is transitional in nature between basin and platform. In Tremadocian time, dramatic changes occurred in the Welsh Basin. A 'soft' accretionary tectonic event at the southern margin of the Irish Sea in late Tremadocian - early Floian time juxtaposed the Monian and Avalonian composite terranes along the margin of Gondwana (Gibbons, 1990; Schofield et al., 2008; Waldron et al., 2011). Van Staal et al. (1998) speculated that the MCT is a correlative of the Gander Terrane of Newfoundland and Maritime Canada, and that the accretion event is correlative to the Penobscotian Phase recognised in the Appalachians (see below). In both Wales and North America, a late Floian to early Darriwilian (mid to late Arenig) overlap sequence containing a 'Celtic' fauna (Neuman, 1984) postdates terrane amalgamation. Deformation extended into the Welsh Basin too, and the early Floian Garth Grit (Fig. 9) is strongly transgressive above a regional unconformity (Rushton and Fortey, 2000). The calc-alkaline Treffgarne and Rhobell volcanic groups (probable late Tremadocian) record onset of subduction beneath Avalonia (Bevins et al., 1984; Kokelaar, 1986).

In Anglesey, dating of detrital zircons from the South Stack Group indicates that the Monian Supergroup is no older than mid-Cambrian (Murphy et al., 2004). The accretion of the MCT to the margin of Gondwana, probably occurred in late Tremadocian time (as described above). The Rosslare Complex in SE Ireland, at the western end of the horst (Fig. 10) comprises similar elements to the MCT. North of the Wexford Boundary Fault System, in the Leinster Basin, deformed low-grade quartz- and chlorite-rich turbidites of the Cullenstown Formation (mid-Cambrian Cahore Group, Bennett et al., 1989) probably correlate with lower parts of the South Stack Group (Tiezsch-Tyler and Phillips, 1989).

In the Craven inliers of northern England, the deep water turbiditic strata of the Ingleton Group were isoclinally folded and cleaved (Soper and Dunning, 2005) prior to the deposition of the Dent Group (Katian-Hirnantian) and overlying parts of the Windermere Supergroup (Fig. 9). They have yielded a Cambrian $\mathrm{Rb}-\mathrm{Sr}$ isotopic age (O’Nions et al., 1973). The Ingletonian strata differ in key aspects from the Skiddaw Group strata in the adjacent Lake District Block. There are some similarities to the massive turbidites in the eastern England subsurface, containing abundant clasts of shale e.g. Bardney borehole. Correlative strata to the Ingleton Group proved in the Beckermonds Scar borehole yielded blackened acritarchs indicating an early Ordovician age (Turner, in Wilson and Cornwell, 1982). Although a Precambrian age for the Ingleton Group strata remains a possibility, their location close to the inferred continuation of the MCT into the UK onshore (Figs. 7,11) suggests that a Penobscotian age for the deformation is also possible (Soper and Dunning, 2005). In this case, the age of the Ingleton Group may be slightly older (?late Cambrian or Tremadocian) and a Ganderian affinity likely. The map of Ordovician terrane elements presented here (Fig. 11) adopts this interpretation.

In New England, Newfoundland, Nova Scotia and the Maritime Provinces of Canada, the Gander and Meguma terranes are interpreted as continental margin slope and rise prisms originating on either margin of Avalonia (Landing, 2005; Van Staal et al., 2012). The Gander Zone was originally defined by a distinct sequence of pre-Dapingian polydeformed psammitic and peltic rocks of continental derivation, known as the Gander Group in NE Newfoundland (Van Staal and Zagorevski, 2017) and extending from the Dover Fault to the terrane boundary with the Dunnage Zone, in the west. The group 
fines upward from quartz-rich, commonly tourmaline-bearing psammite to predominantly black shale (O'Neill, 1991). Detrital zircon and titanite ages demonstrate that the psammites are younger than c. $510 \mathrm{Ma}$ (Willner et al., 2014), but older than granitoid intrusions dated at c. $474 \mathrm{Ma}$ (Colman-Sadd et al., 1992). The presence of the graptolite Rhabdinopora demonstrates that the strata range up to the Tremadocian (White et al., 1994; Van Staal and Fyffe, 1995; Van Staal et al., 2003; Tucker et al., 2001; Fyffe et al., 2009). This distinct lithofacies can be traced into southern Newfoundland, Nova Scotia, New Brunswick and Maine (Van Staal et al., 1996). The Gander Group and correlatives are interpreted as a continental margin formed when the microcontinent Ganderia rifted off Amazonia at c. $505 \mathrm{Ma}$ (mid Cambrian) with opening of the Rheic Ocean (Van Staal et al., 2012). The Penobscotian tectonic cycle is restricted to Ganderia and started while the latter was still attached to the NE edge of Amazonia, with initiation of the Penobscot Arc at c. 515 Ma (Colman-Sadd et al., 1992; Van Staal et al, 1996; 2012). Extension in the arc resulted in formation of both a back-arc oceanic marginal basin (now preserved as the Penobscot ophiolites) and the Rheic Ocean Basin, opening of which separated Ganderia from Amazonia after c. 505 Ma (mid Cambrian) (Van Staal et al., 2012). The Penobscotian Deformation Phase, between 485 and $478 \mathrm{Ma}$ (Tremadocian), is associated with obduction of the back-arc ophiolites onto the Gander margin of Avalonia (Colman-Sadd et al., 1992; Van Staal et al., 1994; Van Staal et al., 2011) and inversion of the back-arc basin.

Waldron et al. (2011) have commented on the gross similarity of the Cambrian sequence in the Welsh Basin to that of the Meguma Terrane in Nova Scotia, in terms of lithology, sedimentary facies and composition. Both comprise early Cambrian sandstone turbidites overlain by early to middle Cambrian mud-rich and sand-rich units with characteristic Mn mineralisation. A sandstone unit in Wales exhibits very similar zircon provenances (Neoproterozoic and Palaeoproterozoic) to penecontemporary strata of the Meguma Supergroup in Canada, suggesting proximity of both areas to the West African margin of Gondwana in early Cambrian time. Waldron et al. (2011) designated a new domain, 'Megumia', to include both regions, which were distinct from Avalonia until Early Ordovician time. Later Meguma strata are anoxic, organic-rich turbidites shallowing upward into bioturbated Tremadocian mudstones. Basinal sequences of Ganderian and Megumian type in Wales, Ireland and Newfoundland, interpreted as continental margin/slope deposits exhibit lithological similarity to the tourmaline- and magnetite-bearing deep water clastics of inferred Cambrian age in Eastern England and Belgium. All apparently predate the supposed time of separation of Avalonia, Ganderia and Megumia from the Gondwana margin (see next section), and must therefore have been deposited on the latter. It is currently unclear if the Penobscotian Phase significantly affected the ABM, but the strong folding of pre-Silurian age affecting Cambrian-Tremadocian strata in the Nuneaton district of the English Midlands, described above, suggests that it did. It is also notable that a disconformity (Graulich, 1961; Vanguestaine, 1992; Verniers et al., 2002), representing a hiatus of about 14 Ma, separates the Chevlipont Formation (early Tremadocian) and Abbaye de Villars (upper Dapingian) formations in the Brabant Massif (Fig. 9). If this represents a significant unconformity related to regional tectonic deformation it might explain the apparent contrast in strain observed between the CambrianTremadocian and later Ordovician-Silurian sequences in Belgium (Sintubin, 1997).

\section{The history of the Avalonia Microcontinental Terrane}

\subsection{Introduction}

As described earlier, the concensus view is that the faunally-defined Avalonia microcontinent rifted away from Gondwana at high southerly palaeolatitude in late Early Ordovician (Floian) time (Scotese and McKerrow, 1990; McKerrow et al., 1992; Fortey and Cocks. 1992; 2003; Prigmore et al., 1997; Cocks and Torsvik, 2006; Woodcock, 2012b). Contrary opinions (e.g. Landing, 1996; 2005; Landing 
et al., 2013) were noted in the previous section. In Newfoundland, Van Staal et al. (2012) have presented evidence for a slightly earlier, late Cambrian, departure. Isotopic studies of detrital zircon populations from Cambrian clastic sequences suggest that the situation may be more complex, with different parts of Avalonia having different amounts of cratonic source components (Schofield et al., 2016). This might allow an archipelago of Avalonian fragments to drift diachronously away from Gondwana, allowing some compromise in this debate.

Only the eastern part of this originally ribbon-like microcontinent (or archipelago) is preserved as part of the ABM. The remainder lies west of the Atlantic Ocean, in Newfoundland, Nova Scotia and the Maritime Provinces of Canada and in the Appalachians. As the Avalonia Microcontinent drifted northward, a new (Rheic) ocean basin opened in its wake; and the old (Iapetus) ocean crust was destroyed by subduction zones on both its Laurentian and Avalonian margins. Part of this Iapetus Ocean, referred to as the Tornquist Sea by Cocks and Fortey (1982), lay between Avalonia and Baltica. Faunal contrast with Gondwana only became apparent in Darriwilian (late Llanvirn) time (Woodcock, 2012b). On the Avalonian margin, the earliest subduction magmatism is of late Tremadocian age at Treffgarne and Rhobell in the Welsh Basin (Kokelaar, 1979; 1988; Bevins, 1982). Volcanic arcs developed elsewhere on the microcontinent through subsequent Ordovician time, and in SandbianKatian time a short-lived magmatic arc extended from the Lake District to East Anglia and the Brabant Massif of Belgium (Pharaoh et al., 1991; 1993). This arc records the subduction of part of the Tornquist Sea basin beneath Avalonia (Pharaoh et al, 1993; 1995; Noble et al., 1993; Van Staal et al., 1998) (Fig. 8). Geophysical evidence suggests that at least two subduction zones separated by juvenile accreted arc/marginal basin crust (Pharaoh, 1999; Williamson et al., 2002; Lyngsie and Thybo, 2006) were involved in this process. The less significant one, beneath the D-SHFZ, was described in Section 2; the more significant zone, associated with the Thor-Tornquist Suture, is inferred to have generated the cryptic Southern North Sea Terrane (Williamson et al., 2002). Contemporaneous supra-subduction zone volcanism in Wales and SE Ireland, probably in an ensialic marginal basin (Kokelaar et al., 1984; McConnell et al., 1991; Winchester and Van Staal, 1995), is geometrically compatible with this hypothesis. Faunal contrasts with Baltica broke down in late Ordovician time (Woodcock, 2012b). There is little evidence for 'hard' collision at this time, although Pharaoh et al. (1995) and Pharaoh (1999) speculated that dextral strike-slip and uplift on the Pontesford Lineament, attributed to the 'Shelveian Phase by Toghill (1992), and metamorphism at up to amphibolite facies on the Mid-North Sea High (Frost et al., 1978) may reflect a 'soft' collisional event. The terrane map for the British and Irish Caledonides south of the Iapetus Suture (Fig. 11) is based on Bluck et al. (1992) and incorporates modifications by BGS (1996) following the work of Soper and Dunning (2005). In the ABM, Megasequence 2 of Verniers et al. (2002) is equivalent to the Gwyned Megasequence of Woodcock (1990) in the Welsh Basin (Fig. 9).

\subsection{Sedimentary history of Megasequence 2}

Sedimentary rocks of Ordovician age younger than Tremadocian are almost absent from the Midlands Microcraton (Molyneux, 1991). Rare exceptions include the isolated occurrence of the Lickey Quartzite, near Birmingham, formerly attributed (with doubt) to the Cambrian (Cowie et al., 1972), and now attributed to the Floian (Arenig) (Old et al., 1991; Rushton, 2000); and the transgressive Caradoc strata deposited on the NW edge of the microcraton (Fig. 9), adjacent to the WBFS (Woodcock, 2012b). The limited number of post-Tremadocian Ordovician provings (Figs. 12b, 13) means that knowledge of the Ordovician palaeogeography of the ABM is rather poor. Eyam, Great Paxton and Huntingdon boreholes encountered grey mudstones and siltstones containing shelly faunas (brachiopods, trilobites, orthocone nautiloids and other molluscs (Molyneux, 1991; Rushton, 2012), of Darriwilian (early Llanvirn) age. In the Eyam Borehole, just to north of the microcraton, the cleaved strata dip at $45-60^{\circ}$ 
(Dunham, 1973). Beyond the eastern edge of the microcraton, the strata are uncleaved and dip at 60$70^{\circ}$ to SE in Great Paxton Borehole, or are slightly cleaved (Huntingdon Borehole). Here graptolites are more common and with the Raphiophorid trilobite community (Rushton and Hughes, 1981), may reflect a deeper water, shelf-marginal environment. Intensely bioturbated early Ordovician strata proved by Ironville 5 Borehole (Molyneux, 2001; Pharaoh et al., 2011) and, less well dated, in Thorpe-ByWater Borehole (Molyneux, 1991), may also sit on this shelf edge. The Eakring 146 (Dukes Wood) Borehole proved $84 \mathrm{~m}$ of grey phyllitic mudstones and subordinate sandstones, beneath coarse clastic strata of latest Devonian or earliest Carboniferous age (Edwards, 1967; Kent, 1967). Phosphatic fragments identified in thin section from $2200 \mathrm{~m}$ drilled depth, possibly derived from trilobites and an Acrotreta-like brachiopod, led C.J. Stubblefield (in Edwards, 1967) to infer a possible Cambrian age for these strata (Cowie et al., 1972). The available core, a small set of curated specimens, were reexamined during the present study. This confirmed the presence of dark purple and grey shales, with a unit of strongly altered volcanic rock of andesitic composition, resting upon a massive quartzite. The core is affected by steep bedding dips, veining and slickensides. The shales are unlike any of the phyllitic mudstones within the undated 'quartzite-phyllite association' (section 4), although the quartzites show similarity. The metamorphic grade is high anchizone (Pharaoh et al., 1987a; Merriman et al., 1993), slightly lower than the epizonal grade of the phyllites. Two thin ( $<10 \mathrm{~m}$ thick) flows of altered andesite and dacite occur at $2204 \mathrm{~m}$ and $2240 \mathrm{~m}$ depth, according to the driller's log. A geochemical analysis presented by Pharaoh et al. (1991) is comparable in major and trace element composition to that of andesites proved by Woo Dale and Cox's Walk boreholes, for which an Ordovician age is inferred. On balance, an Ordovician age for the Eakring proving is preferred (contrast with Cowie et al., 1972), and if this is correct, the lower quartzite could be of Floian age. In the vicinity of The Wash, the boreholes at Halton Holegate 1 and UK offshore well 47/29A-1 (Fig. 13) penetrated similar slates and greywackes. In the former, a poorly preserved acritarch flora including Acanthodiacrodium sp. indicates a tentative Early Ordovician age (S.G. Molyneux, written communication in Pharaoh et al., 2011) for this more basinal sequence. A slightly younger macrofauna of ?Sandbian/Katian (Caradoc) age has been reported from Bobbing Borehole in Kent (Lister et al., 1969). Thus, unlike on the platform, a more complete Ordovician succession seems to be present in eastern England (although with very poor thickness control).

In Belgium, a hiatus of about $14 \mathrm{Ma}$, from mid Tremadocian (c. $482 \mathrm{Ma}$ ) to upper Dapingian (c. $468 \mathrm{Ma})$ (Herbosch and Verniers, 2014), is inferred to reflect rifting of Avalonia from Gondwana and opening of the Rheic Ocean (Verniers et al., 2001; 2002). However, the hiatus is comparable in age to the 'Penobscotian' Unconformity (Fig. 9) identified elsewhere in the Caledonides, and attributed to Ganderian/Avalonian collision (see below). $1.3 \mathrm{~km}$ of Ordovician strata (Servais et al., 1993; Herbosch and Verniers, 2013) were deposited during the northward independent drift of Avalonia towards Baltica. Dapingian to Darriwilian strata were deposited in outer to inner shelf, and eventually intratidal environments. Transgressive late Darriwilian to Sandbian strata were deposited during a regional flooding event (Paris et al., 2007). Late Sandbian to mid Katian formations, comprising distal turbidites and hemipelagites, deposited in deeper water, were affected by large slump sheets (Debacker et al., 2001), as were Darriwilian strata. Late Katian strata contain shelly facies. Isolated from Amazonian sources by the opening of the Rheic Ocean, the Mesoproterozoic zircon provenance vanished (Linnemann et al., 2012). In the Condroz Inlier, trilobite assemblages show typical Northern Gondwana/Avalonian affinity up to the Sandbian, but evidence for increasing Baltican proximity in the Katian (Verniers et al., 2002); chitinozoans show a Baltoscandian influence from early Sandbian time (Samuelsson and Verniers, 2000; Verniers, 2005).

\subsection{Volcanic arc magmatism during Megasequence 2}


Numerous boreholes in the concealed Caledonides of eastern England penetrate deformed volcanic rocks. In the north, these are generally encountered beneath a cover of Carboniferous age; farther south, beneath a Mesozoic cover sequence. A comprehensive review of the available isotopic and geochemical data available was presented by Pharaoh et al. (1991). Six boreholes (Woo Dale, Eakring 146, Cox's Walk, Great Osgrove Wood, Sproxton 1, Upwood) lie in a NW-SE trending belt about $150 \mathrm{~km}$ long, extending from the south Pennines to Cambridgeshire, on the western side of the Eakring-Glinton Lineament (Figs. 12,13). The volcanic belt is coincident with prominent linear magnetic anomalies (Allsop et al., 1987; Pharaoh et al., 1993a; 1995; Kirby et al., 2000) described in Section 2, although a contribution from magnetic Cambrian rocks remains a possibility (Lee et al., 1993).

Andesitic lavas were proved in Cox's Walk and Eakring 146 boreholes, as described above, and intermediate tuff and agglomerate in Woo Dale, Hollowell and Upwood boreholes (Figs. 13, 14). Basaltic compositions are uncommon, and reported only from coarse agglomerate at Upwood (Webb and Brown, 1989). Silicic lavas, principally dacite and rhyodacite, were proved by Woo Dale, Cox's Walk and Great Osgrove Wood boreholes. Only the North Creake crystal-lithic tuff occurrence has been reliably dated using the U-Pb technique, yielding a zircon age of $449 \pm 13 \mathrm{Ma}$ (Noble et al., 1993) (Katian). Cox's Walk Borehole on the Foston High proved $243 \mathrm{~m}$ of andesite, dacite and rhyolite lavas. Despite strong alteration, primary igneous textures such as amygdales, flowage texture and zoning in plagioclase, are well preserved (Berridge et al., 1999) and a Rb-Sr whole rock isochron age of $466 \pm 11$ $\mathrm{Ma}$ (Darriwillian) is interpreted as close to the likely age of eruption (Pharaoh et al., 1987a; Pharaoh et al., 1991). The Rb-Sr whole rock isochron age of $399 \pm 9$ Ma obtained for the Wood Dale lava (Pharaoh et al., 1987a) by contrast reflects late Caledonian metamorphic resetting (Pharaoh et al., 1991; Noble et al., 1993). Both of these Rb-Sr ages can only be regarded as minimum estimates for the true age of eruption. Clearly, further studies using U-Pb zircon are required to establish both the contemporaneity of all components, as well as the duration of eruption. If contemporaneity is assumed, the suite defines a well developed calc-alkaline trend involving basaltic, andesitic, dacitic, rhyodacitic and rhyolitic compositions. Strong enrichment of large ion lithophile elements (LILE) such as Ba and Th, light rare earth elements (REE) and relative depletion of $\mathrm{Ti}$ and $\mathrm{Nb}$ reflects a strong subduction magmatic component in geochemical patterns normalised to mid-ocean ridge basalt (MORB) values (Pharaoh et al., 1991). $\varepsilon N d$ isotopic data, ranging from about +2 to -4 , indicate limited involvement of much older crust, unlike the Ediacaran Glinton-Orton volcanics (-6 to -8) (Pharaoh et al., 1991; Noble et al., 1993).

Interbedded with the Sandbian and Katian strata in Belgium, and sometimes intimately mixed with them, are pyroclastic rocks of dacitic and rhyolitic composition (André et al., 1986; 1991; Verniers et al., 2002). Volcanic activity lasted from 486 to 433 Ma reaching a peak in late Katian time, but continued with decreasing intensity until end Telychian (early Silurian), later than in the English ABM (Linnemann et al., 2012). A number of silicic sub-volcanic plugs and sill complexes are also present, aligned in a belt straddling the WNW-ESE trending Nieuwport-Asquempont Fault Zone (NAFZ). RbSr isotope studies of the fabric within the fault zone indicate Givetian displacement (André and Deutsch, 1985). The subduction-related origin of this magmatism has been disputed by Linnemann et al. (2012), who invoke an intra-plate magmatic origin, for the following reasons:

1). Arguments for S-dipping subduction based on the presence of calc-alkaline rocks in the north (Brabant) and tholetiitic rocks in the south (Ardennes) (e.g. Andre et al., 1986) are invalid due to the gross age difference. This is almost certainly correct, but the argument for such a polarity (in England) made by Pharaoh et al. (1991, 1993, 1995, 1999) was based on other, more robust criteria, specifically geophysical evidence from deep seismic reflection data for a crustal suture beneath the DSHFZ, 80-150 $\mathrm{km}$ outboard of the calc-alkaline arc in England, as described in Section 2.

2). Brabant magmatic rocks exhibit high-K calc-alkaline to alkali-calcic composition, uncommon in subduction settings and more typical of post-collisional and intracontinental settings. Notwithstanding the fact that the Alkali-Lime Index (Linnemann et al., 2012, Figure 7A) is based on 
major elements all notoriously subject to mobility during alteration and metamorphism, the MORB normalised profiles of the Brabant rocks (Linnemann et al., 2012, Figure 7G) exhibit strong enrichment in LILE (e.g. Th), light REE (Ce, Nd), Hf and Zr, and depletion of Nb, P and Ti, characteristic of highK calc-alkaline suites, and comparable to those of the English ABM (Pharaoh et al., 1991) reviewed above. The shoshonitic affinity of the Brabant magmatism confirmed by Figure 7B of Linnemann et al. (2012) is here considered to reflect a higher degree of partial-melting at greater than 'usual' depth in the subduction zone, because of the thicker crust and lithosphere beneath the ABM (Section 2).

3). The Brabant Massif was a passive margin setting in Ordovician time. This statement is here considered unproven, as both in Belgium and England, Megasequence II strata are characterised by increasing depth of deposition with time, and abundant tectonic instability (e.g. the Asquempont and Buttermere Formation detachments, described below), reflecting volcanic marginal basin development.

4). No trench is available at a reasonable distance, the nearest being located several hundred $\mathrm{km}$ to the NE. Linnemann et al. (2012) appear unaware of the argument for the presence of at least two, SSWdipping subduction zones within the 'Tornquist Basin' sensu lato, one, probably short-lived, beneath the D-SHFZ (Pharaoh et al., 1995; Verniers et al., 2002, Fig. 8), 80-150 km outboard of the inferred arc; and another several hundred $\mathrm{km}$ farther NE, beneath the Elbe Lineament (Pharaoh, 1999; Williamson et al., 2002; Verniers et al., 2002, Fig. 8; Lyngsie and Thybo, 2006).

In our present understanding, the lithosphere of the Tornquist Sea may have included oceanic marginal-basins of various sizes (now subducted), and juvenile accreted arc components (Williamson et al., 2002), ascribed to a Southern North Sea Terrane (Franke, 1995; BGS, 1996; Pharaoh, 1999) or 'Far Eastern Avalonia Terrane' (Winchester et al., 2002; Verniers et al., 2002). The latter could equally comprise, older Ganderian, or younger, entirely Ordovician, accreted arc, recording destruction of the larger Tornquist ocean basin. Before its closure, the Tornquist Sea therefore had greater resemblance to the western margin of the present Pacific Ocean, e.g. the Japan and Philippine seas, than the E Pacific margin.

Calc-alkaline volcanic centres in Eastern Avalonia have subsequently been invoked as the source of bentonite (volcanic ash) horizons, representing fall-out from Plinian eruption columns, in both Baltica (Torsvik and Rehnström, 2003) and the Małopolska Terrane in SW Poland (Trela et al., 2017). The thickest of these bentonites (140 cm thick) at Kinnekulle in SW Sweden, has been dated at $457 \pm$ $2 \mathrm{Ma}\left(\mathrm{U}-\mathrm{Pb}\right.$ zircon age cited in Tucker and McKerrow, 1995) and $455 \pm 2 \mathrm{Ma}\left({ }^{40} \mathrm{Ar} /{ }^{39} \mathrm{Ar}\right.$ biotite age, Min et al., 2001) (Sandbian). With a calculated eruptive volume of $1000 \mathrm{~km}^{3}$ (Huff et al., 1996) this is one of the largest known Plinian eruptions in the geological record. The age of the Kinnekulle eruption is identical within errors to the dates of magmatism within the ABM (and Wales and the Lake District), and it will be interesting to see if increasing precision of the dating technique is eventually able to identify the actual 'smoking caldera'.

\subsection{Arc-related plutonism}

Plutonic and hypabyssal magmatic rocks of the Caledonian orogenic cycle are highlighted as red coloured patches in the English part of Fig. 13. Only the composite Lake District batholith, Shap granite, Mountsorrel and South Leicestershire intrusions crop out. The calc-alkaline affinities of the Leicestershire intrusions were described by Le Bas $(1972 ; 1982)$, and he encouraged the author to research their possible relationship with volcanic rocks in Belgium described by Luc André and colleagues $(1986,1991)$. Other plutonic rocks are proven by deep boreholes at Weardale, Wensleydale, Rempstone, Warboys, Moorby (Millward, 2006), and most of these bodies have now been dated radiometrically. The presence of several other plutonic and hypabyssal intrusions is inferred from geophysical evidence, including possible granitic bodies at Market Weighton (Bott et al., 1978) and the adjacent offshore Eastern England Shelf (Donato and Megson, 1983). Two phases of plutonic 
magmatism are recognised in the English Caledonides. The first, in mid Ordovician time (c. $460 \mathrm{Ma}$ ) is penecontemporaneous and comagmatic with the subduction-related volcanic arc magmatism described above. The second phase, emplaced in early Devonian time (c. $395 \mathrm{Ma}$ ) and syn- to latecollisional in nature, is contemporaneous with the eruption of Lower Old Red Sandstone volcanic rocks, e.g. in the Cheviot. As the ABM does not appear to contain any intrusions of the second phase, these will not be further considered here.

At least two NW-SE trending belts of intrusions are present within the Caledonide fold-thrust belt lying to north of the Midlands Microcraton. The southern belt of intrusions includes the calc-alkaline diorite-granodiorite-tonalite association cropping out in Leicestershire at Mountsorrel, Croft and Enderby (Le Bas, 1972; 1982) but also proved in the sub-surface by boreholes at Rempstone, Kirby Lane and Warboys (all so far undated). The U-Pb age for the Mountsorrel Granodiorite presented by Pidgeon and Aftalion (1978) was recalculated with slightly larger errors to $452 \pm 10 \mathrm{Ma}$ (early Katian) by Noble et al. (1993). The northern belt of intrusions includes the sodic Wensleydale Granite (Dunham, 1974) and the plutonic bodies inferred to underlie the Market Weighton Platform (Bott et al., 1978) and The Wash (Chroston et al., 1987; Allsop and Evans, 1988). Pharaoh et al. (1997) speculated that the sodic Moorby Microgranite, penetrated by the Claxby Borehole a little north of The Wash (Fig. 13), and dated at $457 \pm 20 \mathrm{Ma}$, might be a sub-volcanic representative of this same suite. Comparable sodic granites at crop in the Lake District Massif (Ennerdale Granophyre, Eskdale Granite) have yielded precise $\mathrm{U}-\mathrm{Pb}$ ages of $452 \pm 4$ and $450 \pm 3 \mathrm{Ma}$ (Katian) respectively (Hughes et al., 1996). An $\varepsilon \mathrm{Nd}(\mathrm{t})$ value of -1.74 for the Moorby intrusion indicates the involvement of a small amount of pre-existing crust in its petrogenesis (Noble et al., 1993). Although the northern belt of intrusions is presently poorly characterised, they are considered to have played a significant structural role in the behaviour of the crust of northern England in post-Caledonian time. Thus the Wensleydale Granite underpinned the Akrigg Block of the northern Pennines in Carboniferous and later time, imparting a buoyancy and rigidity which caused subsequent Variscan inversion structures to be deflected at the southern margin of the block (Kirby et al., 2000, their Figure 4). The inferred Market Weighton Granite underpinning the Hornsea High has exerted a persistently buoyant influence throughout the Mesozoic, as expressed in the sedimentary record (e.g. Kent, 1968; Bott et al., 1978); and the putative Wash Batholith may have played a role in controlling the tectonic behaviour of the northern margin of the ABM, particularly in Carboniferous time. Both the Wensleydale and Moorby bodies have yielded whole rock $\mathrm{Rb}$-Sr isochron ages of c. 400 Ma (early Devonian) (Dunham, 1974; Rundle, 1979; 1992). These ages are however discordant to the $\mathrm{U}-\mathrm{Pb}$ zircon ages, and must reflect pervasive hydrothermal alteration and spaced crenulation cleavage development during late Caledonian deformation (Pharaoh et al., 1987).

\subsection{Minor intrusive suite and subduction shutdown}

In addition to the large plutonic bodies described above, numerous smaller bodies belonging to the lamprophyric-microdioritic Midlands Minor Intrusive Suite (Carney et al., 1992; Carney and Pharaoh, 1993; Pharaoh et al., 1993a; Henney et al., 1993) and of spessartitic affinity (Rock, 1984) are encountered in exposed Cambrian-Tremadocian strata (e.g. Wrekin, Nuneaton, Rubery, Malverns) and numerous boreholes throughout the microcraton. They are not observed to intrude Silurian strata however, as noted by Wills (1948, Fig. 3). These geological observations are compatible with the U-Pb baddeleyite age of $442 \pm 3 \mathrm{Ma}$ (earliest Silurian or latest Ordovician) for pegmatoid facies of a differentiated sill belonging to this suite, in the Mancetter area near Nuneaton (Noble et al., 1993). Field observations indicate that the minor intrusions were emplaced in a number of co-magmatic pulses (Eastwood et al., 1923; Le Bas, 1968; Thorpe et al., 1993). In some places, dykes cut the axial planes of chevron folds of bedding in Cambrian-Tremadocian strata . A post-Tremadocian/pre-Silurian age is therefore inferred for this deformation (Carney et al., 1992; Bridge et al., 1998), for which a 
Penobscotian cause is therefore conceivable. The mineralogical and geochemical composition of these minor intrusions indicates formation by small degrees of partial melting of lithospheric mantle with subduction enrichment of volatiles, LILE and light REE. A within-plate mantle source also provided a contribution. The Midlands Minor Intrusive suite and comparable lavas in North Wales (see below) have been interpreted to reflect the shutdown of volcanism (and subduction) at the northern edge of Avalonia (Woodcock, 2012b).

In Brabant, magmatism continued until $433 \mathrm{Ma}$ (end Telychian, early Silurian), significantly later than in the English ABM (Linnemann et al., 2012). This is possibly a consequence of oblique closure of the Tornquist Sea basin (Pharaoh et al., 1995); or even more speculatively, with a polarity switch of subduction, with Rheic oceanic lithosphere being subducted to the north (as in southern England at this time, Section 6.2).

\subsection{Comparison with post-Tremadocian Ordovician sequences elsewhere in the Caledonides}

In Wales, the basal Arenig (Floian) quartzite oversteps from the Welsh Basin onto the Irish Sea Horst. The quartzite is significantly thicker $(>1000 \mathrm{~m})$ in the vicinity of the WBFS and MSFS (Brenchley et al., 2006), suggesting extensional reactivation of both lineaments following the earlier Penobscotian accretionary tectonism. Volcanism resumed in Dapingian time following a significant break (?8 Ma) in Floian time. Dapingian to Katian mudstone sequences, intercalated with the volcanic units, were deposited in a number of fault-controlled basins (Woodcock, 2012b), in water of shelf depth. Some of the volcanic centres emerged above sea level (Kokelaar et al., 1984; Howells et al., 1990). The volcanics comprise bimodal basalt-rhyolite suites with an asthenospheric mantle source, reflecting transition of the Welsh Basin to a back-arc setting. The youngest volcanics (c.454 Ma) have an ocean island basalt signature, reflecting the shutdown of subduction beneath North Wales (Leat et al., 1986; Leat and Thorpe, 1989). Woodcock (2012) has proposed that the distinctive chemical signature results from detachment of the leading half of the downgoing plate following subduction of the mid-Iapetus spreading ridge. In this way the asthenospheric mantle can be tapped through a window in the subducting slab, yielding the unusual compositions observed in the minor intrusive suite. The situation is analogous to that in the present day Gulf of California (Woodcock, 2012b). Following ridge subduction, the new plate boundary amalgamating Laurentia with Avalonia would have had a significant component of dextral strike-slip. The strands of the WBFS were reactivated in Hirnantian time during the so-called Shelveian deformation phase (Toghill, 1992), with dextral strike-slip (Lynas, 1988; Woodcock, 1988). This deformation may also reflect intra-plate stress resulting from the soft docking of Avalonia with Baltica, following closure of the Tornquist Sea (Pharaoh, 1996; 1999; Woodcock, 2012b).

In Leinster north of the Wexford Boundary Fault System, Cambrian and early Ordovician deep marine, turbidite-dominated strata crop out. Similar deep water strata in the Lake District and Isle of Man range down to the Tremadocian, but Cambrian strata are not yet proven (S.G. Molyneux, pers.comm.). Large synsedimentary slump sheets and debris flows testify to the instability of the continental margin (Webb and Cooper, 1988; Cooper et al., 1993). The deep water sequences of the Ribband, Manx and Skiddaw groups (Fig. 9) lack the prominent intra-Tremadocian unconformities visible in the Midland Platform and Welsh Basin (Woodcock, 2012b). They are therefore attributed to a distinct Leinster-Lakesman Terrane (Murphy et al., 1991; Bluck et al., 1992), which apparently occupied a more outboard position on the Avalonian margin (Fig. 11). An alternative view, preferred here, is that the Leinster-Lakesman volcanosedimentary package represents a juvenile addition to Avalonia, and is not therefore a separate terrane. The post-Tremadocian history in south Leinster is akin to that of the Welsh Basin, with subduction-related Tremadocian volcanism giving way to DarriwillianKatian back arc bimodal suites (Woodcock, 2012). In north Leinster and the Lake District, Sandbian 
and Katian andesites (e.g. the Eycott and Borrowdale volcanic groups) are the submarine to sub-aerial eruption products of a continental arc, while overlying intermediate to silicic pyroclastic rocks up to 4 km thick, infill at least 5 major calderas (Millward et al., 1978; Millward, 2002). Subduction-related volcanism waned and shut down in later Katian time, either because of docking with Baltica or because the Iapetus Ocean Ridge had been overrun (Woodcock, 2012b). The dissimilarity of the volcanic rocks in the Leinster-Lakesman Domain to those in Wales led Kokelaar (1998) to propose that the terranes were not adjacent in Ordovician time, but had been juxtaposed by sinistral strike-slip subsequently. In latest Ordovician time, the basins of the Leinster-Lakesman Domain were starved of clastic debris (Woodcock, 2012b); deposition of shelf limestones was interrupted by Hirnantian eustatic sea-level fall.

The mid- to late Ordovician arc volcanic rocks in the Lake District have no obvious equivalents farther west in the northern Appalachians (Van Staal et al., 1998). The Floian-Dapingian PopeloganVictoria Arc developed on the leading edge of Ganderia following renewed southward subduction in late Ordovician time, colliding with the Red Indian Lake Arc of composite Laurentian margin in the final phase of Taconic deformation, at about $455 \mathrm{Ma}$ (Van Staal et al., 2009). The Tetagouche-Exploits ensialic back-arc complex of New Brunswick and Newfoundland developed on a Ganderian substrate and with SE-directed subduction resembles the situation in the Welsh Basin. Faunal provinciality broke down in late Ordovician time when Scoto-Appalachian faunas replaced peri-Gondwana faunas in the Exploits Subzone (Van Staal et al. 1998), much earlier than in Eastern Avalonia.

In conclusion, the concealed eastern part of the ABM apparently contains a more complete postTremadocian succession than the platform to the west, where strata of this age are almost completely absent. The post-Tremadocian Ordovician strata of the eastern ABM appear more comparable to those of the Brabant Massif than the Lakesman-Leinster Domain or Welsh Basin. The subduction history in eastern England and Belgium is significantly different to that of the Newfoundland, Maritime and New England Caledonides, reflecting likely spatial variation in arc polarity and diachroneity of trench/volcanic arc development and ocean-ridge/trench collision throughout the length of the Iapetus Ocean (Van Staal and Winchester, 2017).

\section{Silurian successor basins and Rheic-related volcanism}

\subsection{Introduction}

Following the shutdown of subduction, and a brief period of erosion during the Hirnantian (latest Ordovician) glacial-eustatic sea level lowstand, the lithosphere of Avalonia cooled and subsided. Avalonia now lay at a palaeolatitude of about $30^{\circ} \mathrm{S}$, with Baltica juxtaposed to NE (in present day reference frame), and a rapidly closing Iapetus Ocean (transforming to a strike-slip margin) to the NW (Fig. 8). In Silurian time, a eustatic sea-level rise following the Hirnantian lowstand flooded the platform. A major transgressive system tract of early Llandovery age defines the base of Megasequence 3, equivalent to the Powys Megasequence (Fig. 9) recognised in the Welsh Basin by Woodcock (1990; 1991). Impingement of Eastern Avalonia with Laurentia resulted in the development of a series of successor, foreland basins receiving immature detritus from the evolving orogenic belt (Woodcock, 2012c).

\subsection{Platformal sequences of Megasequence 3}

On the Midland Platform, the Hirnantian Unconformity is overlain by transgressive sandstones and shallow marine mudstones deposited in a series of pulses until latest Llandovery time. In the adjacent Welsh Massif, up to $3000 \mathrm{~m}$ of Llandovery strata were deposited in the rapidly subsiding Woolhope and Usk basins (Butler et al., 1997). Shales with a shelly fauna of Llandovery age, were encountered in 
Batsford and Shalford boreholes, and Wenlock shales in Cliffe and Ware boreholes (Bassett, 1974; Bassett et al., 1992). The occurrences are key data points for defining the edge of the Midland platform (Fig. 15). Brabourne Borehole, in Kent, containing dark shales (Lamplugh and Kitchin, 1911), with rare brachiopod and trilobite fragments of probable late Llandovery or earliest Wenlock age (Molyneux, 1991), probably lies on the shelf edge. The early Llandovery strata of the Brabant Massif were also deposited on a shelf, before the basin deepened from late Telychian time on (Fig. 9).

\subsection{Magmatism during Megasequence 3}

Silurian strata contain interstratified volcanic sequences reflecting renewed subduction, but not on the old Iapetus-Tornquist template. Volcanic centres at outcrop include Skomer in SW Wales (midLlandovery), Tortworth, in Gloucestershire (upper Llandovery), and the Mendips (mid-Wenlock) (Van de Kamp, 1969; Thorpe et al., 1989); lavas of Llandovery age are also encountered in boreholes at Maesteg in south Wales, Netherton (Harrison, 1974) and Bicester (Pharaoh et al., 1991, Fig. 14). The lavas form a reflective marker horizon on reflection seismic lines and can be mapped between the borehole provings. All of the volcanic centres are located within about $50 \mathrm{~km}$ of the Variscan Front, anticipating the subsequent development of the Variscides (Turner, 1935; Pharaoh et al., 1991; 1993; Fortey et al., 1996). In addition, thin ash (bentonite) horizons are more widely distributed both spatially and temporally (Fortey et al., 1996), but may not necessarily have been derived from the same volcanic centres (Woodcock, 2012c). The chemical composition of the lavas varies from basalt through basaltic andesite to minor amounts of rhyolite, with both within-plate and subduction magmatic signatures (Thorpe et al., 1989; Pharaoh et al., 1991). Distinct peralkaline and ocean island basalt series are recognised at Skomer (Thorpe et al., 1989), while the Mendips and Tortworth occurrences have calcalkaline affinities (Van der Kamp, 1969). This could either reflect development of an extensional rift zone on the northern margin of the Rheic Ocean, with a lithosphere previously contaminated by (Avalonian or Iapetan) subduction (Pharaoh et al., 1991); or subduction of the Rheic Ocean northward under the Avalonia plate (Fortey et al. 1996; Woodcock, 2012c), following a polarity switch. Given the faunal evidence which appears to favour opening of the Rheic Ocean from Floian time (perhaps earlier) onwards (Scotese and McKerrow, 1991; McKerrow et al., 1991; Cocks and Fortey, 1992), some 30 to $40 \mathrm{Ma}$ earlier than the Skomer volcanism, the latter hypothesis presently looks the most reasonable. As noted above, in Brabant, magmatism continuing until $433 \mathrm{Ma}$ (early Silurian time) (Linnemann et al., 2012) might also be associated with a polarity switch to northward subduction of the Rheic Ocean.

\subsection{Basinal sequences of Megasequence 3}

The strong contrast in character and composition of the Caledonian basement in the eastern part of the ABM compared to the platform to the west has been known since the 1940's (Bullard et al., 1940; Wills, 1948). The chains of plutonic and volcanic bodies inferred to be present in the subcrop to NW terminate close to Cambridge. Silurian biostratigraphic ages have been confirmed for metasedimentary rocks proved by nine boreholes in East Anglia and Kent (Molyneux, 1991; Bassett et al., 1992): Brabourne, Chilham, Clare, Cliffe, Lowestoft, Soham, Stow Langtoft, Stutton and Weeley (Figs. 12b, 13). UK offshore well 53/16-1 (Cameron et al., 1992) and Dutch offshore well O18-1 (De Vos et al., 2010) provide a link to the continuation of the basin into the Brabant Massif. In addition, boreholes at Culford, East Ruston, Harwich, Herne, Isle of Grain, Saxthorpe, Sheerness, Somerton and Reculver (Fig. 15) are thought to have penetrated Silurian rocks (Cocks et al., 1971; Wills, 1978) but this has still to be confirmed. Ellingham, Eriswell and Rocklands boreholes reached early Palaeozoic strata, possibly Silurian, although the borehole records are rather poor. The basinal subcrop defined by these boreholes is considered to define the limits of the Anglian Basin (Woodcock and Pharaoh, 1993), the counterpart 
of the Silurian Welsh Basin (Fig. 15). The boreholes at Cliffe and Ware are key data points defining the eastern edge of the platform (Fig. 15).

To the NE, all boreholes prove basinal facies. Woodcock and Pharaoh (1993) recognised four sedimentary facies, two or three of which may be grouped into each of four facies associations. Facies Association A, unbioturbated mudstones, are most prevalent in boreholes proving Llandovery to Wenlock strata, e.g. at Weeley and possibly in the less well dated Harwich, Ellingham, Saxthorpe and Somerton provings. The facies association is comparable to the Wenlock 'laminated hemipelagites' of the Welsh Basin (Dimberline et al., 1990) and an outer shelf or marine basin slope environment is inferred (Woodcock and Pharaoh, 1993). Facies Association B, dominated by graded and bioturbated mudstone, becomes more prevalent in Ludlow and Př́dolí provings (e.g. Stutton and Lowestoft), and was probably deposited in an oxygenated outer shelf environment. Facies Association C, comprising graded sandstones and mudstones, frequently bioturbated, is found in Př́dolí age provings at Clare, Lakenheath and Soham. An oxygenated muddy outer shelf, like association B but with greater sand supply, and probably shallower water conditions, is proposed. Facies Association C passes up into Facies Association D (bioturbated sandstones) of Přídolí age at Lakenheath, Soham and Stow Langtoft, comprising about equal proportions of ungraded sandstone and graded mudstone. A storm-dominated inner shelf environment is proposed. Given the presently rather poor biostratigraphic age constraints, the variation of the facies associations can interpreted in terms of space or time. In the areal hypothesis, the Anglian Basin deepens away from the Midland Platform into oxygenated shelf and anoxic outermost shelf or basin slope, returning to shelf conditions in the NE e.g. in well 53/16-1. The temporal hypothesis for the facies distribution invokes a systematic change with time, from anoxic outer shelf/basin slope in Llandovery and Wenlock, greater oxygenation and increasing sand supply through Ludlow time, to progressive shallowing of the shelf and increasing influence of storm-dominated sedimentation, in Přídolí time. Without further detailed biostratigraphic studies of the borehole material, it is difficult to distinguish between these two end members for the variation of facies associations (Woodcock and Pharaoh, 1993). In contrast to the Welsh Basin (from late Llandovery time) and the Lake District Basin (from late Wenlock time), no major influxes of sandy turbidity flows, ascribed to diachronous collision between the eastern part of Avalonia with Laurentia (Soper and Woodcock, 1990), have been recognised in the Anglian Basin. Much of central and northern Britain was emergent at this stage (Bassett et al., 1992).

In Belgium, the base of Megasequence 3 is now defined at the base of the Madot Formation (upper Katian) (e.g. Verniers et al., 2002; Herbosch and Verniers, 2014). In the outcrop area, the megasequence comprises c. $3.4 \mathrm{~km}$ of latest Ordovician to early Devonian strata (Verniers et al., 2001; 2002). The base of the megasequence marks a sharp transition from deep sea to shallow shelf, accompanied by a volcanic event. Llandovery strata were initially deposited on a shelf, but upper Telychian to Gorstian strata are deep water turbidites, initially distal, becoming more proximal from the Sheinwoodian (J. Verniers, pers. comm.), reflecting the influx of detritus eroded from the Scandian orogenic welt to north and, significantly, from the Ardennes in the south, reflecting the onset of Brabantian tectonic inversion (Debacker et al., 2014). Mesoproterozoic zircons (from Baltica) reappear in the (Sheinwoodian) Corroy Formation (Linnemann et al., 2012).

\subsection{Comparison with Silurian sequences elsewhere in the Caledonides}

The Welsh Basin was sourced mainly from the west, probably from the collision zone between Western Avalonia and Laurentia, starting in late Llandovery time (Woodcock, 2012c). In late Ludlow and Př́́dolí time, the basin began to shallow and invert, sedimentation becoming terrestrial by Lochkovian time. River systems flowing southward of the developing mountain front were deposited as Lower Old Red strata in South Wales. In northern England, predominantly mud- and silt-dominated 
sequences accumulated in late Llandovery and Wenlock time. Anoxic mudstones were deposited in marine basins with circulation increasingly restricted by oceanic closure. In early Wenlock time, the Leinster Basin received an influx of turbidite sandstones fed from Laurentia. In the Lake District, the turbidite influx arrived slightly later, in Ludlow time, and was sourced mainly from the north-east, probably from the Scandian collision zone between Baltica and Laurentia (Woodcock, 2012c). The Windermere Supergroup of the southern Lake District was deposited in a southward propagating foreland basin (Kneller, 1991; Millward et al., 2000), resulting from flexure of the lithosphere caused by the Laurentian upper plate overriding the Avalonia-Ganderia margin.

In New England, Newfoundland and the Maritime provinces, faunal provinciality broke down in the late Ordovician, Scoto-Appalachian faunas replacing peri-Gondwana faunas in the Exploits Subzone (Van Staal et al., 1998), much earlier than in the eastern zone of Iapetus. Baltica (in the NE) and Western Avalonia (in the SW) were the first terranes to collide with Laurentia following subduction and closure of the Iapetus Ocean, resulting in the early Silurian Scandian and Salinic orogenic phases, respectively. The Salinic deformation reflects closure of the Tetagouche-Exploits back arc basin at 445$425 \mathrm{Ma}$ (late Ordovician-late Silurian). Parts of Ireland (Grangegeeth Terrane) may have collided with Laurentia earlier than the Bellewstown and Leinster-Lakesman terranes. The Grangegeeth Terrane, lying within splays of the Navan-Silvermines Fault (=Iapetus Suture) in eastern Ireland (Harper and Parkes, 1989), shows a similar early breakdown of faunal provinciality. These faunas are distinctly different to the Anglo-Welsh faunas of the Lake District and the Laurentian faunas of the Southern Uplands in the Caradoc. By contrast the adjacent Bellewstown Terrane contains volcanic rocks and Anglo-Welsh faunas most like those of the Welsh Basin (Winchester and Van Staal, 1995; Harper et al., 1990). Following the Salinic deformation, an extensive foreland basin formed on the Ganderian margin in early to late Silurian time. Strata of the Fredericton Trough in the northern Appalachians (Van Staal and de Roo, 1995) and the Badger Group of Newfoundland (Williams et al., 1975; Van Staal et al., 1998) are lithologically comparable to the Windermere Supergroup of the Lake District (Kneller, 1991) and the Anglian Basin (Woodcock and Pharaoh, 1993). In the Meguma Terrane, Silurian riftrelated volcanic and sedimentary rocks (White Rock formation) unconformably overlie the supergroup, and the post-Tremadocian Ordovician record is missing (Waldron et al., 2017). The Megumia, Avalonia and Ganderia terrane elements remained distinct until later in the Palaeozoic (e.g. Valverde-Vaquero et al., 2006; Van Staal et al., 2009).

To conclude, the Silurian strata of the eastern ABM are comparable to those deposited in foreland basins following continental collision, throughout the Caledonides. More comprehensive comparison, particularly with the key Belgian exposed sequence, will only be possible following more detailed studies, including biostratigraphic zonation and detrital provenance of the English provings.

\section{Late Silurian to early Devonian ('late Caledonian/Ligerian') orogenic deformation}

\subsection{Introduction}

All of the early Palaeozoic sedimentary and volcanic units of the ABM described above, and some of the plutonic bodies, were affected by deformation during late Silurian to early Devonian time. Since the 1980's, this deformation has been attributed to the Acadian phase (e.g. McKerrow et al., 1985; Soper et al., 1987; Pharaoh et al., 1987), by analogy with the deformation in the 'Acadian' type area of the northern Appalachians, and the Maritime Provinces of Canada. The term was transferred to the British Caledonides in the last decades of the $20^{\text {th }} \mathrm{C}$ (e.g. McKerrow et al., 1985; Soper et al., 1987). Until recently, it was assumed that all components of the 'slate belts' of southern Britain were deformed during the Acadian deformation. The Acadian phase clearly postdates the collision of Laurentia with Avalonia by 15-20 Ma (Soper and Woodcock, 2003; Woodcock and Soper, 2006; Woodcock, 2012d), 
so it has nothing to do with the closure of the Iapetus Ocean, and the term 'proto-Variscan' might actually be more appropriate (Woodcock et al., 2007), for reasons which will be outlined below. In the Brabant Massif, deformation of the Brabantian Phase started earlier (Verniers et al., 2002), and there is now increasing evidence that this earlier deformation also affected the eastern England sector of the ABM. Acadian deformation occurred within a regime of sinistral transpression (Dewey and Strachan, 2003), followed by transtension in early Devonian time (Soper and Woodcock, 2003). The role of continental promontories and embayments in causing local variation in magnitude of strain and diachroneity of deformation within the Caledonides has been more widely recognised in recent years (Van Staal et al., 2009; Van Staal and Barr, 2012).

\subsection{Tectonic fabrics}

Soper et al. (1987) recognised that the pattern of deformation in the 'slate belts' of Wales and northern England was compatible with indentation by the Midlands Microcraton (Fig. 16), around which the Acadian cleavage appears to arc. The Acadian cleavage in the slate belts shows arcuate swings in trend and is usually non-axial planar. Clockwise transection of folds is common, and together with sinistral displacement on SW-NE striking fault zones, reflects a sinistrally transpressive regime in the Welsh and Cumbrian Caledonides (Soper et al., 1987; Woodcock, 2012c). The concealed Caledonides of eastern England, including deformed Silurian strata of the Anglian Basin as young as Přídolí in age (Molyneux, 1991) were considered to have been affected by the Acadian deformation (Pharaoh et al., 1987). The indentation tectonic model presented by Soper et al. (1987) viewed the Midlands Microcraton as a rigid 'indenter' surrounded by more strongly deformed 'slate belts'. Within the southern British Caledonides, the intensity of tectonic fabrics is lowest in the Midlands Microcraton, where only a bedding planar fissility of diagenetic origin may be present (Pharaoh et al., 1987). However, even here, strong folding of Tremadocian sequences is inferred from borehole evidence, and observed in outcrop (Carney and Pharaoh, 1993) and could result from the Penobscotian Phase, as described earlier. The grade of metamorphism within the microcraton is low, typically diagenetic zone (Pharaoh et al., 1987; Merriman et al., 1993), with a temperature of about $200^{\circ} \mathrm{C}$, although a NW-SE trending belt with slightly higher anchizone grade is observed to parallel the inferred NE margin of the microcraton (Fig. 17). To the NE, into the concealed Caledonides of eastern England, metamorphic grade rises to anchizone and epizone values (temperature exceeding about $300^{\circ} \mathrm{C}$ ) in early Palaeozoic rocks encountered in deep boreholes. In general, the grade is higher in the ?Cambrian quartzites and phyllites (epizone, equivalent to greenschist facies) than in Ordovician and Silurian strata (typically anchizone). Unfortunately none of the cores from the rather old boreholes are orientated, and few have microresistivity logs, so the actual orientation of the fabrics is known in only a few cases. Neither have the strong tectonic fabrics in these cores been dated by radiometric methods. Thus fabrics affecting the Silurian rocks are clearly of Brabantian or Acadian age (see below); those affecting the ?Cambrian quartzite/phyllite association might have been generated earlier, as in Anglesey (Schofield et al., 2008). These are important questions which should be addressed by drilling. In Belgium, there is evidence for only one axial planar cleavage (Sintubin, 1999; Verniers et al., 2002).

\subsection{Age of deformation}

In the best exposed areas of the British Caledonides south of the Iapetus Suture, the 'slate belts' of Wales, Cumbria and the Isle of Man, the age of terminal Caledonide deformation is constrained by major angular unconformity. The youngest pre-deformation sequences in the Welsh Borders and South Wales are of Emsian age (Woodcock, 2012d); Old Red Sandstone strata of likely Lochkovian age at Red Wharf Bay in Anglesey are cleaved. Radiometric ages on the cleavages in the slate belts range from 404 to $390 \mathrm{Ma}$ (Emsian-early Eifelian). The most robust and precise age for the cleavage in Wales, 
$396.1 \pm 1.4 \mathrm{Ma}$, was provided by a study of white mica in cleavage pressure fringes using ${ }^{40} \mathrm{Ar} /{ }^{39} \mathrm{Ar}$ laser microprobe analysis (Sherlock et al., 2003).

A study of the tectonic fabrics in the Neoproterozoic-age Charnian Supergroup, metamorphosed at epizonal grade (= greenschist facies) (Pharaoh et al., 1987; Merriman et al., 1990; Merriman and Kemp, 1997) and exposed in a structural high on the NE flank of the microcraton, revealed that the situation is more complex. The ${ }^{40} \mathrm{Ar} /{ }^{39} \mathrm{Ar}$ laser microprobe method yielded total fusion spot ages of c. 435 to 413 $\mathrm{Ma}$ (late Silurian-earliest Devonian) for the penetrative cleavage and ductile shear zones associated with epizonal metamorphism of the Charnian sequence (Carney et al., 2008). Step-heating yielded slightly more precise ages in the range 418 to $415 \mathrm{Ma}$, considered the most likely age of deformation associated with dextral transpression along the NE flank of the microcraton (Carney et al., 2008). These ages are comparable to those of the youngest (Př́dolí) strata in the Anglian Basin (Molyneux, 1991; Woodcock and Pharaoh, 1993). In Belgium, ${ }^{40} \mathrm{Ar} /{ }^{39} \mathrm{Ar}$ mica ages of 419-412 Ma in the Brabant Massif (Dewaele et al., 2002), are attributed to the Brabantian deformation phase (Debacker et al., 2005). The end of Brabantian deformation is stratigraphically constrained to the Givetian (c. $390 \mathrm{Ma}$ ), the age of the unconformably overlying Bois de Bordeaux Formation (Verniers and Van Grootel, 1991; Van Grootel et al., 1997). The ${ }^{40} \mathrm{Ar} /{ }^{39} \mathrm{Ar}$ ages (426 to $393 \mathrm{Ma}$ ) obtained for syn- to post-cleavage white mica grains place the end of the orogeny at 393 Ma (Debacker et al., 2005). This raises the possibility that the Caledonides of the Anglo-Brabant Deformation Belt (ABDB) (Pharaoh et al., 1993b; 1995; Van Grootel et al., 1997; Winchester et al., 2002) were deformed slightly earlier than those of northern and western Britain (Woodcock, 2012d). It is also interesting to note that this is the time of the Salinic deformation phase in Newfoundland (Van Staal and Zagorevski, 2017). Clearly, further studies are needed to confirm these results, in particular radiometric dating of pelitic lithologies within the concealed Caledonides. They nevertheless indicate that the late Silurian-early Devonian deformation and metamorphism was a protracted and complex event, and may have involved early deformation at orogenic promontories prior to the 'terminal' Acadian phase

\subsection{Terrane and intra-terrane rotations}

Several palaeomagnetic studies have provided evidence for significant rotation of Avalonia from late Ordovician to early Devonian time. Torsvik (1998) and Torsvik and Rehnstrom (2003) identified significant counterclockwise rotation of Baltica and Avalonia during their northward drift from moderate southerly palaeolatitudes in early Ordovician time to the Equator in middle Devonian time. This may account for the rotation of the Welsh Basin from arc to back-arc location during Ordovician time (Pharaoh, 1993; 1995), as inferred from the geochemical evidence (Kokelaar, 1988). Waldron et al. (2011), recognising the similarity of Cambrian deep water facies in the Welsh Basin to those of Megumia, advocated the possibility of significant post-Cambrian counterclockwise rotation of East Avalonia in one of their Cambrian plate reconstructions.

Piper (1997) identified c. $55^{\circ}$ of post-Katian/pre-Devonian intraplate counterclockwise rotation of the Lake District with respect to North Wales, of probable Acadian age. Verniers et al. (2002) suggested that this rotation may have contributed to the long-lasting (Wenlock-early Eifelian) Brabantian Deformation, during which the core of the Brabant Massif was uplifted. Vizan et al. (2003) identified an even larger (c. $165^{\circ}$ ) clockwise rotation of of the Midland Platform at Nuneaton. The rotation apparently has a post-Hirnantian, pre-Carboniferous age, again presumed to be Acadian. These latter observations are however difficult to reconcile with the inferred lack of rotation of the ABM with respect to putative subduction zones in the North Sea since the end of Ordovician time.

\subsection{Causes of late Caledonian orogenic deformation}


Closure of the Rheic ocean basin, with impingement of the Armorican or Iberian microcontinents upon Avalonia, was invoked as the cause of the Acadian Orogeny by Soper et al. (1987). The MidDevonian Acadian Phase is contemporaneous with the Ligerian or 'Eo-Variscan' Phase recognised throughout the Variscides (Ziegler, 1990; Matte, 2001). High pressure metamorphism of this age is identified in numerous Variscan Massifs e.g. NW Iberia, southern Armorica and Bohemia (Lardeaux et al., 2014) and reflects collision and obduction of continental terranes in an early ('Eo-Variscan') phase of the Variscan Orogeny. It seems likely that Avalonia was involved in these collisions, albeit peripherally.

Some form of collision between Armorica and Cornubia (Variscide Rhenohercynian zone on the southern margin of Avalonia) in Devonian time is indicated by the presence of olistoliths embedded in a mid- or late Devonian olistostrome in south Cornwall (Barnes et al., 1979; Leveridge and Shail, 2011). The Roseland Breccia Formation ('Gorran Quartzite') contains trilobite-brachiopod fauna placed as late Darriwilian, comparable to that of the Grès de May (Armorican Quartzite) in Brittany. Some blocks are up to $1.5 \mathrm{~km}$ long. Dark blue limestone clasts contain orthocone nautiloids, brachiopods and bivalves of late Silurian to early Devonian age. However, actual evidence for Acadian compressional deformation is missing in Cornubia (Woodcock et al., 2007), as apparently is the early Devonian arc produced by northward subduction of Rheic Ocean lithosphere. The evidence for the presence of such an arc parallel to, and just north of the subsequent Variscan Front in Silurian time, was reviewed above. Instead, the 'Lizard Ophiolite' seems to indicate the presence of either a marginal basin or possibly a hyper-extended continental margin (Shail and Leveridge, 2009) here in mid-Devonian time, rather than a compressional belt. An alternative explanation invokes subduction of a young buoyant segment of Rheic ocean ridge, resulting in 'flat-slab subduction' and a strong shear stress on the Avalonian lithosphere, sufficient to have driven the Acadian deformation (Woodcock et al., 2007; Woodcock, 2012e). This should result in a hot thermal pulse, resulting in partial-melting ('migmatisation') of the continental crust. This is observed in western Newfoundland, where migmatitic leucosome in the large amphibolite-facies Meelpaeg Nappe has yielded a U-Pb zircon age of $418 \pm 4 \mathrm{Ma}$ (early Devonian) (Currie et al., 1991). This metamorphism, which mainly affects the Gander Zone east of the Red Indian Line (i.e. the Iapetus Suture), is at much higher grade than Acadian metamorphism in the UK however, which cannot be attributed to such a thermal pulse.

To resolve these difficulties, Woodcock et al. (2007) and Woodcock (2012) envisaged displacement of the arc/forearc system on the northern Rheic margin by about $400 \mathrm{~km}$ of dextral shear along a putative Bristol Channel-Bray Fault Zone, the presence of which had already been advocated by Holder and Leveridge (1986). The hypothesis proposes that the crust of what is now Cornubia originated in what is now the western side of the Paris Basin, and was translated to its present position in post Acadian or early Variscan time, possibly during the late Carboniferous (Woodcock, 2012e; p207). The hypothesis is both elegant and attractive, and could explain the displacement of Acadian deformed crust farther west along the Variscan Orogen, for example to the allochthonous HP terranes of NW Iberia. The geophysical evidence for a major fault (possible suture) between the Isle of Wight and the Pays de Bray is convincing (Hamblin et al., 1992). However, it is the author's view that there is no convincing evidence in any of the geophysical datasets reviewed in Section 2 for the direct continuation of the Bray Fault Zone from the Isle of Wight to the Bristol Channel, even though significant geophysical expression, including Moho offset, might be expected. This is not to say that individual fault segments e.g. the Bristol Channel faults (e.g. Miliorizos et al., 2004), the Watchet-Quantocks Fault System, the Cranborne-Fordingbridge faults (Whittaker, 1985) and the Wight-Bray Fault (Hamblin et al., 1992) do not exist; simply, that they do not appear to form a coherent linked system between the Bristol Channel and the Isle of Wight, as proposed by Holder and Leveridge (1986) and Woodcock (2012). The organic maturity of Devonian-Carboniferous strata of the Rhenohercynian Zone on either side of the putative 
fault zone is comparable (Smith, 1993), suggesting no significant offset, although this should be confirmed by further studies of mica crystallinity and other low grade metamorphic indicators. Neither is any offset apparent in the magnetic potential field data (Fig. 5a). NW-SE trending, relatively straight faults such as the Watchet-Cothelstone and Lustleigh-Sticklepath zones are explicable in terms of late Variscan dextral strike-slip and Alpine reactivation under relatively brittle conditions.

A further complication is a geodynamic one. As will be discussed in a later section (Variscan Orogeny), the North Armorican Domain appears to have been in close juxtaposition to Cornubia in late Devonian time, although neither may have been in their present location relative to Laurussia. However, if the interpretation of Variscan dynamics presented below is correct, the movement of the North Armorican promontory late in the orogeny was principally northward and orthogonal to the orogenic front, with only a limited strike-slip component. If the promontory was impinging on Cornubia as early as late Devonian time (Leveridge and Shail, 2011), the window of opportunity for Cornubia to disperse westward around the promontory against the regional orogenic dispersal direction would seem to be very short, restricted to about $11 \mathrm{Ma}$ of mid-Devonian time.

It is the author's view, as described earlier, that a magmatic arc related to Rheic subduction was present at the southern margin of Avalonia in Llandovery to Wenlock time. The remains of this presently lie close and parallel to the Variscan Front (Pharaoh et al., 1991; Fortey et al., 1996). No younger Silurian to early Devonian arc volcanics have been identified, perhaps because they were subsequently eroded. This interpretation is permissible given the position of the Devono-Carboniferous unconformity in the sub-surface. The detritus may have ended up in the Welsh Basin which received a significant amount of juvenile volcanic detritus in latest Př́́dolí time (Thorogood, 1990). Flat-slab subduction, pulling on the thickened crust of the Midlands Microcraton may have played a role too (Woodcock, 2012). The fore-arc basin would now have to lie concealed beneath early Devonian basins in Cornubia. Furthermore, prior to late, possibly significant low angle nappe translation during the later stages of the Variscan Orogeny, Cornubia lay on the southern margin of Avalonian crust (Cocks et al., 1997), in a southward extension of the Midland Platform. At the time of Acadian deformation, the Avalonian crust beneath Cornubia may have been just as rigid as that beneath the Midland Platform (where Acadian deformation is slight). It may even have lain in a zone of lower strain in an orogenic embayment on the western flank of the North Armorican Promontory, as suggested by Fig. 28. The zone of high Acadian strain extended SW into the Celtic Sea and Western Approaches, where it presumably controls the geometry of subsequent Mesozoic extension (Gardiner and Sheridan, 1981); and the counterpart Brabantian zone of high strain (A-BDB) extends SE into Belgium.

In conclusion, some combination of a 'push from the south' by the North Armorica Domain or related terranes and flat slab subduction of the Rheic Ocean is still favoured as the cause of late Caledonian deformation surrounding the ABM, although the significant problems with the hypothesis identified by Woodcock et al. (2007) and (Woodcock, 2012) are acknowledged.

\section{The Anglo-Brabant Massif comes of age in late Palaeozoic time}

\subsection{Introduction}

By early Devonian time, the accretionary collage of the Caledonide Orogen had been welded into a mountain belt, part of the supercontinent known as 'Laurussia', or the 'Old Red Continent' (Ziegler, 1990). This was a period of orogen-wide sinistral transtension (Dewey and Strachan, 2003; Soper and Woodcock, 2003), most obviously expressed in sinistral displacement on major fault zones such as the Great Glen and Highland Boundary fault systems, but also associated with voluminous granite magmatism, erosion of the Caledonide mountains and transport of the clastic detritus southward to basins of 'Old Red Sandstone' (ORS). Beyond the northern limits of the Midlands Microcraton, the 
Lower ORS strata are only locally preserved, e.g. in isolated basins in Anglesey, in the Cheviot Massif and possibly, in the Isle of Man, where the N-S trending Peel Graben preserves redbed strata of probable Devonian age (although see Quirk and Kimbell, 1997). Soper and Woodcock (2003) have predicted that the orientation of such Lower ORS basins in northern Britain should reflect a W-E extensional element within the post-orogenic transtensional regime. On the southern limit of the microcraton in contrast, basins of mid to late Devonian age witness N-S compressional events reflecting closure of the Rheic Ocean (Leveridge and Shail, 2011). Subsequently, in Mississippian time (Fig. 18), a regime of north-south crustal extension became established, and may be associated with the opening of a relatively narrow and short-lived, Rhenohercynian ocean basin (Leeder, 1978; Franke et al., 2017).

\subsection{Devonian}

As noted above (section 5), the ABM appears to contain no granite intrusions of proven early Devonian age, unlike the Caledonides of northern England (Millward, 2006) and Scotland. Either the transtensional regime was insufficiently intense to permit decompression melting (Vaughan, 1996) and intrusion, or the tectonic and geothermal regime did not facilitate crustal melting, or both. Note that although the Moorby Microgranite has yielded a $\mathrm{Rb} / \mathrm{Sr}$ isochron age of $400 \pm 9 \mathrm{Ma}$ (early Devonian), the U-Pb zircon age (Pharaoh et al., 1997) shows that this is a reset age, a phenomenon observed elsewhere in the British Caledonides (Evans, 1989). Considerable thicknesses (up to $2500 \mathrm{~m}$ ) of early Devonian strata are preserved in South Wales and the Welsh Borders to west of the Malvern Line (Fig. 19); and in a W-E orientated synclinal basin underlying the Thames Valley (Fig. 20), extending from Gloucestershire to east Kent (Mortimer and Chaloner, 1972; Ellison et al., 2004). The strata are mainly fluviatile sequences deposited in extensive braidplains (Allen, 1974; 1979) fed by ephemeral streams into a foreland basin lying to south of the Caledonian Mountains. At this time the ABM does not appear to have had a significant topographic expression. Presumably the lithosphere was flexurally depressed by the orogenic massif to the north. Illite crystallinity data (Pharaoh et al., 1987a; Merriman et al., 1993) indicate that most of the ABM, characterised by diagenetic metamorphic grades, had only a thin cover of ORS, of perhaps only a few hundred metres. By contrast, the metamorphic grade in the ABDB, in greenschist facies, suggests the presence of an early Devonian cover perhaps $3 \mathrm{~km}$ thick (Merriman et al., 1993; Soper and Woodcock, 2003). Two provings (Rocklands, Eriswell boreholes) have incomplete records indicating the possible presence of thin Devonian strata overlying Př́dolí strata in this district (Fig. 19). All other stratigraphic evidence for a thick Devonian cover has been removed by erosion. Early Devonian strata are notably absent beneath the Permo-Triassic Worcester Graben (Fig. 19). They were probably deposited, but eroded following severe Variscan inversion along the axis of the Tremadocian proto-graben. Strong cleavage in the Lower Old Red Sandstone of Anglesey, and ${ }^{40} \mathrm{Ar} /{ }^{39} \mathrm{Ar}$ cleavage dates, indicate that orogenic compression within the Acadian Phase persisted until Emsian time (previous section). Middle Devonian strata are absent from the ABM, but are preserved on its southern margin, e.g. at crop in Cornwall and Devon and concealed beneath the Weald and Wessex basins (right hand edge of Fig. 19).

Late Devonian strata onlap onto the southern margin of the ABM (Allen, 1979), forming the northward extension of the Rheic marine basin (Figs. 19, 20). They are also concealed by Mesozoic strata in Hampshire, Surrey and Kent (Allen, 1979). The end of orogenic compression allowed the depressed crust beneath the ABM to rebound, exerting a palaeotopographic influence for the first time. In addition, incipient N-S extension allowed the deposition of Upper Old Red Sandstone strata in shallow basins in the Midlands (Nuneaton, Eakring?) and on the Central Lancashire High (e.g. Boulsworth-1 and Roddlesworth-1 boreholes). These isolated occurrences are preserved beneath a more extensive cover of Carboniferous strata. 


\subsection{Carboniferous}

By early Carboniferous time, a N-S extensional regime had become established, possibly resulting from back-arc extension (Leeder, 1978; Franke et al., 2017) in the hinterland of volcanic arcs established on the southern margin of Laurussia. Three major pulses of rapid extension and subsidence have been observed in the Mississippian strata of the Carboniferous Limestone Supergroup deposited across a wide, equatorial platform in north Wales and northern England (Gawthorpe et al., 1989; Fraser et al., 1990). Major discontinuities in the sequence are recognised along the northern margin of the ABM. These range from hardgrounds, karstification surfaces and palaeosol horizons (Walkden, 1983; Bridges and Chapman, 1988), to strong angular unconformities. In the East Midlands e.g at Breedon (Ambrose and Carney, 1997), strong discordance between lower and upper Visean sequences may reflect footwall uplift following particularly intense episodes of extension (Fraser et al., 1990) affecting the marginal terraces of the main Carboniferous basins. The orientation of the latter is strongly controlled by the structural template of the underlying Caledonide basement. Hence SW-NE structural trends are dominant in North Wales and the western Pennines, NW-SE trends in the eastern Pennines (Fig. 21). Uppermost Mississippian (Serpukhovian) strata in England belong to the Bowland Shale and Millstone Grit groups (Fig. 18, Waters et al., 2013). Rejuvenation of the Caledonian mountains in Scotland, Greenland and Norway led to the development of major river systems over $1000 \mathrm{~km}$ long transporting coarse clastic detritus southward into the former area of carbonate deposition (Lancaster et al., 2017). Southward prograding deltaic systems are first recognised in Arundian time in the Scottish Borders (Fell Sandstone), and had reached the ABM by Arnsbergian time. Although the northern source was dominant, the ABM had sufficient topography to produce detritus now found in southerly-sourced turbidite units (Mixon-Morridge Formation) in Staffordshire, south Derbyshire and Nottinghamshire (Chisholm and Hallsworth, 2005; Hallsworth and Chisholm, 2017). The patterns of deposition are complicated, influenced by the residual (compaction) subsidence legacy of the earlier extensional basins, the positive buoyancy of the ABM and the effect of glacio-eustatic sea-level variation.

The northern margin of the ABM is strongly indented (Fig. 22), as noted by Fulton and Williams (1988), and the position of the coastline would have shifted to and fro in response to global eustatic sealevel change and more localised basin subsidence. The effects of the former were probably particularly significant in late Carboniferous-early Permian time due to (Dwyka) glaciation in the southern hemisphere. The eastern extremity of the ABM merges with the South Hewett Shelf in the southern North Sea, off The Wash (Fig. 22). Westwards into the onshore, the southern bounding fault of the Coningsby Half-graben (Pharaoh et al., 2011) defines a relatively sharp tectonic boundary, with granites of the inferred Wash Batholith (Figs. 5b, 10) lying in its footwall. Farther west, the southern margins of the Sleaford and Widmerpool half-graben are offset $15 \mathrm{~km}$ by the Denton Fault, a Carboniferous transfer fault representing reactivation of the more ancient Glinton-Eakring Lineament (Figs. 10, 22) (Pharaoh et al., 2011). The Widmerpool Half-graben extends for about $100 \mathrm{~km}$ in a WNW-ESE direction, gradually diverging from the northern edge of the ABM (Figs. 22, 23). In the eastern part of its southern margin, the Hathern Shelf is a marginal shelf between 5 and $10 \mathrm{~km}$ wide, with the Sileby Fault acting as the syndepositional controlling fault. Thick Tournaisian evaporitic strata (Hathern 1 borehole) supports the contention of Fraser et al. (1990) that the Sileby Fault formed the southern limit of extension and subsidence at this time. The basement of the shelf is composed of cleaved Cambrian mudrocks (Carney and Ambrose, 2017) intruded by granodiorite bodies in at least two places (Rempstone 1, Kirby Lane Melton boreholes). As further pulses of extension and subsidence occurred through Mississippian time, the greatest downthrow ( $>4 \mathrm{~km}$, Pharaoh et al. 2011) became localised on the more northerly Hoton, Normanton Hills and Mackworth faults, extending to the North Staffordshire Basin (Fig. 21). The presence of Ordovician granodiorite intrusions may have played a role in this basinward offset of the faulting, by welding and providing buoyant support to the Hathern Shelf. Divergence of the bounding fault system of the Widmerpool Half-graben, probably due to reactivation 
of the Thringstone Lineament at the eastern edge of the Midlands Microcraton, led to the development of a platform with thin Carboniferous cover and mild faulting extending westwards from the Hathern Shelf into south Staffordshire (Fig. 22). The Ticknall Borehole (Carney and Ambrose, 2017) proved 82 $\mathrm{m}$ of buff to grey/green fluvial sandstones and conglomerates, with interbedded red palaeosols of probable Holkerian age, overlain by a thin sequence of fully marine carbonates of the Peak Limestone Group (Asbian-Brigantian). The latter contain several karstic and calcrete horizons. Much thicker $(>300$ $\mathrm{m}$ ) and older sequences of Mississippian strata are exposed in the quarries at Breedon, just $4.5 \mathrm{~km}$ to the east, reflecting onlap onto the faulted northern edge of the ABM. The Redhouse Sandstone Formation proved by the Caldon Low Borehole (Chisholm et al., 1988) is another example of such subaerial clastic strata, although these are preserved beneath Tournaisian carbonates; similar redbeds of probable early Carboniferous age are preserved elsewhere (e.g. Eakring 146 Borehole). Quarries in Brigantian-age limestones at Grace Dieu, south of Ticknall, formerly exposed conglomerate beds containing Charnian pebbles (Kent, 1968), indicating the persistence of the Charnwood Massif through Mississippian time. The southern onlap of the Carboniferous Limestone Supergroup onto the Welsh Massif is demonstrated by good exposure in south Wales and the Bristol Channel area, but is obscured on the southern margin of the ABM. Several deep hydrocarbon wells in the Weald Basin encounter such strata south of the Variscan Front; and a thin Visean sequence in the vicinity of Cambridge may record a localised marine incursion from the NW or south.

Sediments derived from the ABM dominated deposition in the southern part of the Pennine Basin (Fig. 23) until late Kinderscoutian times when a northern source became dominant (Evans et al., 1968; Fraser and Gawthorpe, 2004; Chisholm and Hallsworth, 2005; 2017). In late Mississippian and early Pennsylvanian (Namurian) times, quartzose sandstones (Minn, Morridge, Ipstones Edge sandstones, and equivalents, Figs. 24, 25a) displaying palaeocurrents from the S, SW and W were deposited in the western part of the Widmerpool Half-graben, the North Staffordshire Basin (e.g. Evans et al., 1968; Ashton, 1974; Aitkenhead et al., 1985; Chisholm et al., 1988). The age profiles of detrital zircon grains support derivation of the sands from a Devonian sandstone cover on the ABM (Hallsworth et al., 2009; Morton et al., 2015). The first feldspathic sandstones ('Millstone Grit') of undoubted northern provenance (Fig. 24) are of late Kinderscoutian age (Hallsworth and Chisholm, 2017), and entered the North Staffordshire Basin from N and NW (Ashton, 1974). A similar pattern is revealed by boreholes in the central part of the Widmerpool Half-graben (Duffield, Rempstone 1 boreholes) pre-Marsdenian sandstones being fine-grained and quartzose, with palaeocurrents from SE and SW (Morton et al., 2015: Hallsworth and Chisholm, 2017). Feldspathic sandstones were laid down across the region from midMarsdenian times (Roaches and Ashover Grits, Figs. 24, 25b). Palaeocurrents from the SE have been interpreted to indicate that a major river system extended down the area now occupied by the North Sea and was deflected NW into the Widmerpool Half-graben as it encountered the ABM (Jones, 1980; Collinson, 1988; Chisholm and Hallsworth, 2005). By late Marsdenian time, the northerly derived feldspathic Chatsworth Grit (Figs. 24, 25c) was deposited across the entire region (Waters et al., 2008). The Rough Rock (Yeadonian) was transported by two fluvial systems, the main (feldspathic) from the NE, and a subsidiary (mixed ABM and northern sources) from the SE (Bristow, 1988; Hallsworth and Chisholm, 2008). Heavy mineral suites (e.g. zircon, monazite, chrome spinel, garnet, apatite, tourmaline, rutile) and their ratios, provide evidence in support of the above interpretation. The quartzose sandstones (derived from the $\mathrm{ABM}$ ) have higher content of chrome spinel and low monazite content. Variation in the ratio of chrome-spinel to zircon suggest at least three separate lobes of sediment being fed from the ABM into the North Staffordshire Basin (Hallsworth and Chisholm, 2017). Garnets from these sandstones show similarities to spessartine-rich garnets from the Upper ORS at Merevale (Hallsworth et al., 2000) and it is likely that these strata acted as temporary storage for detritus derived by erosion of the Caledonide Orogen. However, the borehole evidence indicates that most of the ORS was subsequently stripped from the ABM and reworked into Carboniferous strata. The feldspathic 
sandstones (Millstone Grit, with a northern source) contain much more monazite, and pyrope-rich almandine garnets indicate a high grade metamorphic source (Evans et al., 2001: Chisholm and Hallsworth, 2005; Hallsworth and Chisholm, 2008; Hallsworth and Chisholm, 2017). Radiometric dating of zircons identified a likely source in the Greenland Caledonides (Morton and Whitham, 2002; Lancaster et al., 2017).

Studies of Westphalian heavy mineral assemblages suggest that the same distinction between southern and northern provenances persisted into later Pennsylvanian time. Sediment from the developing Variscan Orogen in central Europe arrived from the SE in Yorkshire (Hallsworth and Chisholm, 2000; Hallsworth et al., 2000; Evans et al., 2001) in late Duckmantian time; in east Derbyshire in earliest Bolsovian time; but by direct routes across the ABM only at the start of Westphalian D time (Besly and Kelling, 1988; Glover and Powell, 1996; Hallsworth et al., 2000). This indicates reduction of the topography of the ABM by this time. Pennsylvanian strata onlapping across the Mississippian extensional fault basins described above, reflecting phases of thermal subsidence (Fraser et al., 1990). Early Westphalian strata overstep onto the Hathern Shelf, well beyond the erosional limit of Namurian strata (Pharaoh et al., 2011). They are preserved in several basins on the northern margin of the ABM in Shropshire, Staffordshire, Leicestershire and Warwickshire (Fig. 26), where they overlie strata ranging in age from Silurian to Devonian (Foster et al., 1989). The lower rate of subsidence here resulted in amalgamation of individual coal seams recognised in the basin to one "Thick Coal' up to 9 m thick in the Dudley and Coventry areas (Wills, 1948; Fig. 12). Similar onlap occurred onto the southern margin of the ABM, in Gloucestershire and Kent, but it is uncertain if late Pennsylvanian strata completely covered the massif. Consequently, the ABM can be seen to have played a significant role in controlling the distribution of coalfields, and hence, industrial development, during the Anthropocene. In late Westphalian time, intra-plate stresses from the developing Variscan Orogen of central Europe began to impact the British area, reflected initially in minor sequence discordances, but eventually in the development of a mountain foreland basin complex along the southern margin of the ABM (Besly and Kelling, 1988). Flexural subsidence on a lithospheric scale resulted in downwarping of the crust in a foreland basin in southern Britain, allowing the accumulation of thick late Westphalian to earliest Stephanian 'Barren' and 'Pennant' Coal Measures in Kent, OxfordshireBerkshire and South Wales (Figs. 26, 27), equivalent to the Warwickshire Group (Fig. 18). The lithosphere of the ABM occupying the peripheral bulge to north of the foreland basin would have experienced some degree of complementary upwarping.

\subsection{Variscan Orogeny}

The crust of the UK responded to Variscan orogenic compression in a strongly heterogeneous fashion (Corfield et al., 1996). To north of the ABM, the Mississippian basins responded to Variscan $\mathrm{N}$-S-directed shortening by compressional reactivation of the original extensional faults. The Caledonide basement template in western Britain resulted in strongest compressional reactivation on SW-NE orientated faults, and on NW-SE orientated structures in eastern Britain (Fig. 27) (Corfield et al., 1996). In the immediate vicinity of the northern margin of the ABM, this included reverse movement on fault structures such as the Eakring-Glinton and Thringstone faults, together with the growth of major inversion anticlines (Eakring, Widmerpool anticlines). As described above, the southern margin of the ABM in South Wales, Oxfordshire, Berkshire and Kent (Figs. 26, 27) formed part of the peripheral flexural basin ahead of the Variscan thrust front, and Variscan compression further tightened and preserved these structures. To south of the ABM, the narrow Rhenohercynian Basin (Franke et al., 2017) was closed and inverted, producing thin-skinned nappes containing Devono-Carboniferous strata underlying the Weald and Wessex basins in southern England (Butler, 2017, in press). Orthogonal closure of the Rhenohercynian Basin and crustal shortening brought the North Armorican promontory 
of the Variscan internide zone, and intervening accreted crust of the Saxothuringian Zone underlying the English Channel, into closer juxtaposition with the ABM.

In Figs. 26 and 27, the crust underlying the Permo-Jurassic Worcester Graben, and representing the inverted stump of the Worcester Proto-graben (Section 4) resembles a wedge driven into the Variscan foreland, separating the Welsh Massif in the west from the ABM. The crust in the region between the Malvern Line in the west, and Cerney Wick and Clopton faults in the east, appears to have behaved as a 'mountain front uplift' analogous to structures like the Wind River Uplift lying east of the Rocky Mountains in North America (Gries, 1983), as recognised by Smith (1993). Evidence for this 'Malvernian' phase of uplift was however identified much earlier from studies of outcrop in the Malvern and Abberley Hills (e.g. Groom, 1902) and in the clast content of late Carboniferous and early Permian formations in the Midlands coalfields (Trueman, 1946; 1947; Wills, 1948, Fig. 12). The term 'River Severn Uplift' (e.g. Fig. 26) is introduced here for this Variscan frontal uplift structure, previously referred to as the Worcester High (Smith, 1993), to be redolent of the Rocky Mountain front structures. Strong uplift of the N-S trending axis of the Worcester Proto-graben resulted in removal of perhaps 3 $\mathrm{km}$ of early Palaeozoic strata, together with any Devonian strata, and erosion down to the Precambrian level (Kempsey borehole). Strong inversion occurred on both flanks of the structure, directed westward on the Malvern Line (Chadwick, 1985) and eastward, in a fold-thrust belt on the edge of the concealed Oxfordshire-Berkshire Coalfield (Chadwick and Smith, 1988; Peace and Besly, 1997). This is reflected very clearly in the pattern of subcrop of the Somerset and Bristol Coalfield, to west of the Malvern Line, and the Oxfordshire-Berkshire Coalfield, east of the Clopton Fault (Fig. 26). In the reconstruction shown in Fig. 27, the River Severn Uplift is located immediately opposite the North Armorican promontory. It appears that the latter was perfectly positioned as an indenter during the later stages of the Variscan Orogeny, allowing focussed orogenic stress to exploit the ancient mechanical weakness of the Malvern Line, established as early as Ediacaran time.

\subsection{Permian}

The Clent Breccia of earliest Permian age (c. $298 \mathrm{Ma}$ ) has a highly variable clast composition, reflecting the local provenance of each debris cone (Wills, 1948); at Haffield and Abberley in the west, Malvernian detritus dominates; at Enville, Clent and Nechells, Uriconian; and Charnian at Hopwas and Moira. Clasts of Cambrian quartzite and Llandovery sandstone are present and record the rapid erosion of the River Severn Uplift down to its Precambrian core within perhaps 10 Ma. A major stratigraphic hiatus of c. $20 \mathrm{Ma}$ is associated with the Saalian and Altmark unconformities recognised in central Europe (Fig. 29). In late Permian time (c.260 Ma) the ABM occupied an area of slightly elevated rock desert, to east of the rapidly subsiding Worcester Graben, and south of the low-lying plain in the region of the southern North Sea which would anticipate the Southern Permian Basin (Warrington and IvimeyCook, 1992; Doornenbal and Stevenson, 2010). Its wind-blasted pediments may have formed the source of sand eventually deposited in aeolian dune sandstones in the late Permian Bridgnorth Sandstone (Wills, 1948) in basins on the NW flank of the ABM. The NE margin of the massif, corresponding to a W-E line linking from the west Midlands, via Nottingham to The Wash, persisted into late Permian time (c.254 Ma), and the Zechstein Sea was never able to flood onto the massif.

\section{The Mesozoic history of Anglo-Brabant Massif (London-Brabant Platform)}

\subsection{Introduction}

The buoyant behaviour of the ABM continued into Mesozoic time, as reflected in the preserved onlap for formations of these ages (Fig. 29). The persistence of the ABM as a residual upland in Triassic 
time ('Mercian Highlands') and as a succession of islands within the Jurassic epicontinental sea ('Anglo-Belgian Island') was recognised by Wills (1948), and confirmed by numerous subsequent studies, e.g. Cope et al. (1992).

\subsection{Triassic}

Thin preserved sequences $(<1 \mathrm{~km})$ of Permian and early Triassic strata are restricted to very small areas in NE Norfolk and in isolated basins (e.g. the Hinckley, Knowle, Needwood, Rugby basins) along the northern and western edge of the ABM (Fig. 29) (Whittaker, 1985; Smith, 1985; Newell, 2017, this volume). In early Triassic time (Scythian, c. $246 \mathrm{Ma}$ ), Britain was almost completely occupied by the deserts in which the 'New Red Sandstones' were deposited (Warrington and Ivimey-Cook, 1992). Dominantly fluviatile sandstones of the Sherwood Sandstone Group were deposited in a vast braided river system extending from Northern Armorica via a fairway through south and central England (Newell, 2017, this volume) to marine basins in the southern North Sea and Irish Sea (Fig. 29, line T2). This fairway was tectonically controlled by, and entrained within, the rapidly subsiding Worcester Graben, the latter forming by extensional reactivation of Variscan compressional faults at the margins of the River Severn Uplift. Late Triassic (Carnian, c. 230 Ma) strata of the Mercia Mudstone Group, mainly lacustrine mudstones, onlap farther onto the ABM (Fig. 29, line T3), and were deposited during a phase of regional thermal subsidence. Even the residual topography of the Mercian Highlands at Ashby-de-la-Zouche (Wills, 1948) and Charnwood (Worssam and Old, 1988) was eventually buried. Much greater thicknesses of Triassic strata $(2-6 \mathrm{~km})$ were deposited in the surrounding basins, in the southern North Sea, Irish Sea, Cheshire Basin and Worcester Graben, which form part of the PermoTriassic Central European Basin System (Scheck-Wenderoth et al., 2005), a N-S trending rift system reflecting W-E extension, which initiated the break-up of the Pangaea Supercontinent. Latest Triassic strata (Rhaetian, c. $207 \mathrm{Ma}$ ), represent a marine incursion penetrating even farther onto the massif.

\subsection{Jurassic}

In Jurassic time, extension reoriented to a N-S direction, associated with the rotation of Iberia and the opening of the Bay of Biscay (Chadwick et al., 1989), so that the favourably orientated Variscan compressional structures south of the Variscan Front in southern Britain were reactivated in extension. The ABM lacked internal structures of Variscan age and consequently suffered minimal Jurassic extension (Whittaker, 1985; Chadwick, 1986). Subcrop limits of the Mesozoic formations indicate that the most buoyant part of the ABM now lay farther east, contiguous with the Brabant Massif (Fig. 29). Many authors have used the term 'London-Brabant Platform' or 'London-Brabant High' to describe this part of the massif's history. The main Jurassic subsidence trend is a thickening towards the Worcester Graben, as revealed at crop in the Cotswold region (Fig. 29), towards the Irish Sea, southern North Sea and Cleveland Basin of north Yorkshire. Jurassic sequences exhibit onlap onto the LondonBrabant Platform and a sequence stratigraphy strongly controlled by eustatic sea level control (Figs. 30, 33). The shoreline in early Jurassic times (Hettangian, c. $204 \mathrm{Ma}$ ) had changed little since late Triassic time (Fig. 29, line J1); it occupied a similar position for much of Jurassic time (Fig. 29, line J3, J5, J9). In mid Jurassic time (Aalenian, c. $178 \mathrm{Ma}$ ), regional uplift associated with thermal doming in the North Sea Rift System (Bradshaw et al., 1992), led to a merger of the Welsh and Anglo-Brabant landmasses. A SW-NE trending seaway extending from the Wessex Basin via the Bristol Channel to the East Midlands Shelf (Fig. 29, line J4a), developed intermittently through mid-Jurassic time (Fig. 29, line J5, J7). Renewed subsidence related to extension in late Jurassic time (Whittaker, 1985) once more led to a clear separation of the ABM from the Welsh Landmass (Fig. 29, J9). The seaway reappeared again in latest Jurassic (Volgian, c. 138 Ma) time (Fig. 29, line J11a). 


\subsection{Cretaceous and Cenozoic}

Early Cretaceous strata are absent from the London-Brabant Platform, and a major unconformity (Late Cimmerian Unconformity) is present throughout the massif (Fig. 31), recording a sea-level lowstand as well as renewed uplift. Rising sea level in mid- to late Cretaceous time coupled with regional thermal subsidence allowed the Upper Greensand and Chalk groups to blanket the ABM and conceal its complex tectonic history and composition from direct surface observation.

In early Cretaceous time (Ryazanian, c. $129 \mathrm{Ma}$ ) the ABM and Welsh landmasses were once again united during a sea-level lowstand (Hancock and Rawson, 1992), but rising sea-level through Aptian (c. $109 \mathrm{Ma}$ ) and Albian (c. $97 \mathrm{Ma}$ ) time led to renewed separation of the landmasses and an eastward retreat of the Brabant Landmass towards Belgium (Fig. 29, line K3). In late Cretaceous time (Campanian, c. $85 \mathrm{Ma}$ ), most of England had been submerged by the Chalk sea, leaving only landmasses in Wales and the Lake District. From this time on, the ABM was concealed from view beneath the blanketing Chalk (Figs. 31, 32).

The Alpine Orogeny affected the ABM only slightly, with moderate inversion concentrated to the south, in the Weald and Wessex basins (Variscan Front), in the southern North Sea (Sole Pit Basin) and its margins (Cleveland Basin). The Welsh Massif, decoupled from the ABM by the Malvern Line/Worcester Graben, suffered intermittent uplift and erosion of its Mesozoic and Cenozoic cover, probably as a result of thermally induced uplift associated with plume magmatism (Brodie and White, 1994) and opening of the North Atlantic during early Cenozoic time. Uplift in Belgium in Cenozoic time, perhaps related to Alpine inversion within the Netherlands and/or mantle diapirism beneath the Rhine Graben system (Doornenbal and Stevenson, 2010), led to erosion of the Chalk cover of the Brabant Massif before deposition of Cenozoic strata (Legrand, 1968).

\section{Conclusions}

The surface geology of the south and central Midlands of England, and Belgium, comprising Jurassic, Cretaceous and Cenozoic strata, obscures a 'basement' massif with a long and complex geological history. Various lines of geophysical evidence indicate that the ABM has a strong crust and lithosphere distinct from that of the surrounding geological provinces, although the cause remains uncertain. The crust of the ABM appears stronger and more resistant to deformation than weaker crust surrounding it. As such, it probably represents a more favourable location for long term deep storage (e.g. of radioactive wastes) than the remainder of southern Britain.

The Precambrian history, locally revealed along major lineaments, is a story of Neoproterozoic calc-alkaline arc magmatism, during which the fundamental character of the massif's crust was established. Comparison with Neoproterozoic terranes in Newfoundland suggests that silicic volcanic sequences may form a significant part of the massif's crust, and may have influenced its subsequent behaviour. While granitic intrusions occur locally, e.g. in the vicinity of The Wash, the ABM is, in comparison to granite-underpinned 'blocks' within the Caledonides of northern England, volumetrically deficient in such bodies. Thus the Neoproterozoic silicic crust is inferred to make the greater contribution to the persistently buoyant behaviour of the massif, locally aided by Caledonian granite and granodiorite bodies.

During early Palaeozoic time, strata of three megasequences, known only from deep boreholes in eastern England and limited outcrop in Belgium, exhibit a contrast between platform in the SW, and a basinal area, extending to Belgium, in the NE. The platform shows close lithological affinity to the Avalon Zone of Newfoundland. Undated basinal strata are lithologically comparable to those of Megasequence 1 (Cambrian-Tremadocian) in the Brabant Massif, and both have affinity with basinal 
sequences of the Welsh Basin, and the Gander and Meguma terranes of the northern Appalachians, which represent continental margin/rise strata on the edges of the Avalonia Microcontinent/Terrane. The transition between these domains is obscured by later strata and it is unclear if a terrane boundary is present within the ABM; the presence of metasediments similar to those of the Mona Composite Terrane/Ingleton Group in eastern England, and of a prominent (?Penobscotian) unconformity of early Ordovician age in Belgium, suggest it may be.

In later Ordovician time, the contrast is between emergent back-arc and submarine volcanic arc basins. Sandbian-Katian magmatism is subduction-related (contrast with Linnemann et al., 2012) and extends in an arc from the Lake District through the ABM to Belgium. It is inferred to reflect shortlived subduction of part of the Tornquist Basin beneath Avalonia. This hypothesis requires that the remainder (and largest part) of the basin was subducted beneath the largely hidden Southern North Sea Terrane, now juxtaposed between the Dowsing and Tornquist sutures. By contrast, contemporary volcanism in the Welsh Basin and Leinster occurred in back-arc environments. Comparable arc volcanism of this age is not recognised in North America, confiming the diachroneity of arc development and cessation throughout the Appalachians and Caledonides. In Silurian time, the contrast was between carbonate platform and deepwater basin filled by turbidites fed from the developing orogenic welt between Avalonia, Laurentia and Baltica, and from the Ardennes. This successor basin, which extends directly into the Brabant Massif, is comparable to Silurian successor basins postdating terrane collision throughout the Caledonides.

The western part of the ABM ('Midlands Microcraton') apparently escaped the strong late Caledonian deformation exhibited in the adjacent 'slate belts' in Wales and northern England. Brabantian deformation in the eastern ABM, and in Belgium, began slightly earlier than Acadian deformation in the Caledonides elsewhere. There are still many controversial aspects about the causes of this deformation, which seems to be related to closure of the Rheic Ocean and continental collision in central Europe during the Ligerian or 'Eo-Variscan' orogenic phase.

The part of the Welsh Massif comprising the western part of the Midland Platform/Microcraton exhibits strong contrasts with its counterpart in the ABM. Here strong early Ordovician (Penobscotian?) uplift and erosion led to the removal of virtually all Cambrian strata, except at the margins (Church Stretton Fault, Malvern Line). Consequently Silurian platform strata rest directly upon the Precambrian basement. In addition, the Silurian platform sequences are more tectonically influenced (e.g. Woolhope and Usk basins), depositionally thicker and better preserved than their counterparts in the ABM. A much thicker sequence of early Devonian (LORS) strata is preserved in the west too, although metamorphic evidence suggests the cover in the eastern $\mathrm{ABM}$ was at least as thick prior to erosion.

In the UK, late Palaeozoic sequences onlap onto the ABM from its northern and southern margins. The elevation and subsidence of the western part of the ABM was controlled initially by regional postCaledonian sinistral transtension in early Devonian time, followed by relaxation in late Devonian time, extension in Mississippian time, and thermal subsidence in Pennsylvanian time. In latest Pennsylvanian time, the ABM was flexured in the peripheral forebulge of the Variscan Orogen, separating a strongly inverted southern foreland basin complex from less strongly inverted basins affected by far-field inversion effects. Indentation associated with the North Armorican Promontory of the Variscan Internide Zone exploited the ancient weakness at the Malvern Line and drove a wedge into the Variscan Foreland, further decoupling the crust of the ABM and the Welsh Massif. The River Severn Uplift is viewed as a classic 'Rocky Mountain-style frontal uplift' at the Variscan Front.

Permian to Mesozoic sequences exhibit variable degree of onlap onto the ABM, which continued to express persistent buoyancy in the guise of the London-Brabant Platform. All Mesozoic sequences on the platform are significantly thinner than sequences deposited in the surrounding basins of the southern North Sea, southern England and the Worcester Graben. The development of all of these basins was strongly controlled by extensional reactivation of compressional structures in the subjacent 
(Caledonian and Variscan) basement; reactivation which did not affect the heart of the massif. Jurassic sequences on the platform were strongly influenced by eustatic sea level change. Late Cretaceous strata deposited in a thermal subsidence regime and at a sea level highstand, finally drew a concealing cloak across the platform, but this is unlikely to be the last chapter in the history of the astonishingly persistent Anglo-Brabant Massif.

\section{Acknowledgements}

Mark Woods is thanked for his invitation and encouragement to prepare this review. David Bate also provided much encouragement. The Acadian Unconformity maps upon which several of the figures are based were developed by Nigel Smith throughout his career at the British Geological Survey. The assistance of Geoff Kimbell in the analysis and illustration of the geophysical potential field and the seismic tomographic data is gratefully acknowledged. Stuart Molyneux is thanked for his comments on the biostratigraphic data and early Palaeozoic correlations, and significant improvements to the manuscript. Many diagrams were drawn (or redrafted) by Henry Holbrook. Incisive reviews by internal BGS (P. Wilby) and external referees (J. Verniers, and Anon.) are also gratefully acknowledged. This paper is published with the approval of the Executive Director, British Geological Survey.

\section{References}

Aitkenhead, N A, Chisholm, J I, And Stevenson, I P. 1985. Geology of the country around Buxton, Leek and Bakewell. Memoir of the British Geological Survey, Nottingham, Sheet 111 (England and Wales). Allen, J.R.L. 1974. The Devonian rocks of Wales and the Welsh Borderland. In: T. R. Owen (Ed.). The Upper Palaeozoic rocks of Wales, Cardiff: University of Wales Press, pp. 47-84.

Allen, J.R.L., 1979. Old Red Sandstone facies in external basins, with particular reference to southern Britain. Special Papers in Palaeontology 23, 65-80.

Allsop, J.M. 1987. Patterns of late Caledonian intrusive activity in eastern and northern England from geophysics, radiometric dating and basement geology. Proceedings of the Yorkshire Geological Society 46, 335-353.

Allsop, J.M., Evans, C.J. 1988. Some geophysical aspects of the deep geology of eastern England. Journal of the Open University Geological Society 9, 27-33.

Allsop, J.M., Ambrose, K. , Elson, R. J. 1987. New data on the stratigraphy and geophysics in the area around Hollowell, Northamptonshire, provided by a coal exploration borehole. Proceedings of the Geologists' Association, London 98, 157-170.

Ambrose, K. Carney, J.N. 1997. Geology of the Breedon on the Hill area, 1:10000 sheet SK42SW: part of 1:50000 sheet 141 (Loughborough): British Geological Survey, Nottingham, Onshore Geology Series, Technical Report WA/97/42

Anderson, M.M. Bruckner, W.D., King, A.F., Maher, J.B. 1975. The late Proterozoic "H.D.Lilly Uncoformity" at Red Head, northeastern Avalon Pensula, Newfoundland. American Journal of Science, 275, 1012-1027.

Anderton, R., Bridges, P.H., Leeder, M.R., Sellwood, B.W. 1979. A Dynamic Startigraphy of the British Isles. pp 301. George Allen and Unwin, London.

André, L. 1991. The concealed crystalline basement in Belgium and the "Brabantia" microplate concept: constraints from the Caledonian magmatic and sedimentary rocks. Annales de la Société Géologique de Belgique 114, 117-140.

André, L., Deutsch, S. 1985. Very low-grade metamorphic Sr isotopic resetting of magmatic rocks and minerals: Evidence for a late Givetian strike-slip division of the Brabant Massif, Belgium. Journal of the Geological Society, London 142, 911923.

André, L., Hertogen, J., Deutsch, S. 1986. Ordovician-Silurian magmatic provinces in Belgium and the Caledonian orogeny in middle Europe. Geology 14, 879-882.

Arthurton, R.S., Johnson, E.W., Mundy, D.J.C. 1988. Geology of the country around Settle. Memoir of the Geological Survey of Great Britain.

Ashton, C.A. 1974. Palaeontology, stratigraphy and sedimentology of the Kinderscoutian and lower Marsdenian (Namurian) of North Staffordshire and adjacent areas. Unpublished PhD thesis, University of Keele.

Bamford, D., Faber, S., Jacob, B., Kaminski, W., Nunn, K., Prodehl, C., Fuchs, K., King, R., Willmore, P., 1976. A Lithospheric Seismic Profile in Britain - I. Preliminary Results. Geophysical Journal of the Royal Astronomical Society 44, 145-160.

Bamford, D., Nunn, K., Prodehl, C., Jacob, B., 1977. LISPB - III. Upper crustal structure of northern Britain. Journal of the Geological Society, London 133, 481-488.

Banka, D., Pharaoh, T. C., Williamson, J. P. 2002. Potential field imaging of Palaeozoic orogenic structure in northern and central Europe. Tectonophysics 360, 23-45.

Barclay, W.J., Ambrose, K., Chadwick, R.A., Pharaoh, T. C. 1997. Geology of the country around Worcester. Memoir of the British Geological Survey, Nottingham, Sheet 199 (England and Wales). 
Barnes, R.P., Branney, M.J., Stone, P., Woodcock, N.H. 2006. The Lakesman Terrane: the Lower Palaeozoic record of the deep marine Lakesman Basin, a volcanic arc and foreland basin. In: Brenchley, P.J., Rawson, P.F. (Eds.) The Geology of England and Wales. The Geological Society, London. 2 nd ed.

Barron, H., Molyneux, S.G. 1992a. Fownhope Borehole. British Geological Survey, Confidential Report WH/92/152C.

Barron, H., Molyneux, S.G. 1992b. Fownhope Borehole. British Geological Survey, Confidential Report WH/92/153C.

Barton, P.J., 1992. LISPB revisited: a new look under the Caledonides of northern Britain. Geophysical Journal International 110, 371-391.

Bassett, M.G. 1974. Review of the stratigraphy of the Wenlock Series in the Welsh Borderland and South Wales. Palaeontology 17, 745-777.

Bassett, M.G., Bluck, B.J., Cave, R., Holland, C.H., Lawson, J.D. 1992. Silurian. .In: Cope, J.C.W., Ingham, J.K., Rawson, P.F. (Eds.) Atlas of Palaeogeography and Lithofacies. Geological Society, London.

Beamish, D., Kimbell, G.S., Pharaoh, T.C. 2016. The deep crustal magnetic structure of Britain. Proceedings of the Geologists' Association 128, XXX-XXX.

Bennett, M.C., Dunne, W.M., Todd, S.P. 1989. Reappraisal of the 'Culltenstown Formation': implicationsfor the Lower Palaeozoic tectonic history of SE Ireland. Geological Journal 24, 317-329.

Benus, A.P. 1988. Sedimentological context of a deep-water Ediacaran fauna (Mistaken Point Formation, Avalon Zone, eastern Newfoundland). Bulletin of the New York State Museum 463, 8-9.

Berthelsen, A. 1998. The Tornquist Zone northwest of the Carpathians: an intraplate pseudosuture. Geol Foren Förhandling 120, 223-230.

Besly, B.M., Kelling, G. 1988. (Eds). Sedimentation in a Synorogenic Basin Complex: the Upper Carboniferous of Northwest Europe. Blackie, Glasgow and London.

Bevins, R.E., Kokelaar, B.P., Dunkley, P.N. 1984. Petrology and geochemistry of early to mid- Ordovician igneous rocks in Wales: a volcanic arc to marginal basin transition. Proceedings of the Geologists' Association 95, 337-347.

Bevins, R.E., Bluck, B.J., Brenchley, P.J., Fortey, R.A., Hughes, C.P., Ingham, J.K., Rushton, A.W.A.. 1992. Ordovician, In: Cope, J.C.W., Ingham, J.K., Rawson, P.F. (Eds.). Atlas of Palaeogeography and Lithofacies. Geological Society, London. pp. 19-36. Memoir 13

Bland, B.H. 1994. Trace fossils in the Swithland Formation. Transactions of the Leicester Literary and Philosophical Society $8,27$.

Bland, B.H., Goldring, R. 1995. Teichichnus Seilacher 1955 and other trace fossils (Cambrian?) From the Charnian of Central England. Neues Jahrbuch für Geologie und Palaeontologie (Seilacher Festschrift) 195, 5-23.

Bluck, B.J., Gibbons, W., Ingham, J.K. 1992. Terranes. In: Cope, J.C.W., Ingham, J.K., Rawson, P.F. (Eds.) Atlas of Palaeogeography and Lithofacies. Geological Society, London. pp. 1-4. Memoir 13

Blundell, D. J., 1993. Deep structure of the Anglo-Brabant massif revealed by seismic profiling. Geological Magazine 130, 563-567.

Blundell, D.J., Hobbs, R.W., Klemperer, S.L., Scott-Robinson, R., Long, R.E., West, T.E., Duin, E., 1991. Crustal structure of the central and southern North Sea from BIRPS deep seismic reflection profiling. Journal of the Geological Society, London 148, 445-458.

Bott, M.H.P., Robinson, J., Kohnstamm, M.A. 1978. Granite beneath Market Weighton. Journal of the Geological Society, London 135, 535-543.

Bouckaert, J., Fock, W., Vendenberghe, N. 1988. First results of the Belgian geotraverse 1986 (Belcorp). Annales de la Société Géologique de Belgique 111, 279-290.

Bradshaw, M.J., Cope, J.C.W., Cripps, D.W., Donovan, D.T., Howarth, M.K., Rawson, P.F., West, L.M., Wimbledon, W.A. 1992. Jurassic. In: Cope, J.C.W., Ingham, J.K., Rawson, P.F. (Eds.). Atlas of Palaeogeography and Lithofacies. Geological Society, London. pp 107-129. Memoir 13.

Brasier, M.D., 1984. Microfossils and small shelly fossils from the Lower Cambrian Hyolithes Limestone at Nuneaton, English Midlands. Geological Magazine 121, 229-253.

Brasier, M.D., Ingham, J.K., Rushton, A.W.A. 1992. Cambrian. In: Cope, J.C.W., Ingham, J.K., Rawson, P.F. (Eds.). Atlas of Palaeogeography and Lithofacies. Geological Society, London. pp. 19-36. Memoir 13.

Brasier, M.D. 1992. Introduction. Background to the Cambrian explosion. Journal of the Geological Society, London 149, 585-587.

Brasier, M.D., Hewitt, R.A. 1979. Environmental setting of fossiliferous rocks from the uppermost Proterozoic-Lower Cambrian of central England. Palaeogeography, Palaeoclimatology and Palaeoecology 27, 35-57.

Brasier, M.D., Hewitt, R.A., Brasier, C.J. 1978. On the late Precambrian-early Cambrian Hartshill Formation of Warwickshire. Geological Magazine 115, 21-36.

Brenchley, P., Rushton, A.W.A., Howells, M., Cave, R. 2006. Cambrian and Ordovician: the early Palaeozoic tectonostratigraphic evolution of the Welsh Basin, Midland and Monian Terranes of Eastern Avalonia. In: Brenchley, P.J., Rawson, P.F. (Eds.) The Geology of England and Wales. The Geological Society, London. 2 nd ed.

Bridge, D. McC., Carney, J.N., Lawley, R.S., Rushton, A.W.A. 1998. The geology of the country around Coventry and Nuneaton. Memoir of the British Geological Survey, Nottingham, Sheet 169 (England and Wales).

Bridges, P. H., Chapman, A.J. 1988. The anatomy of a deep-water mud-mound complex to the southwest of the Dinantian platform in Derbyshire, UK. Sedimentology 35, 139-162.

Bristow, C.S. 1988. Controls on the sedimentation of the Rough Rock Group (Namurian) from the Pennine Basin of northern England. In: Besly, B.M., Kelling, G. 1988. (Eds). Sedimentation in a Synorogenic Basin Complex: the Upper Carboniferous of Northwest Europe. Blackie, Glasgow and London.

British Geological Survey, Nottingham. 1996. Tectonic map of Britain, Ireland and adjacent areas. Pharaoh, T.C., Morris,

J.H., Long, C.B., Ryan, P.D., (Compilers). 1:1 500000 British Geological Survey, Nottingham.

British Geological Survey, Nottingham. 1999. Coal Resources Map of Britain. Chapman, G.R. (Coordinator). 
1:1 500000 British Geological Survey, Nottingham and The Coal Authority.

Branney, M.J. 1988. The subaerial setting of the Ordovician Borrowdale Volcanic Group, English Lake District. Journal of the Geological Society, London 145, 887-890.

Bridge, D. McC., Carney, J.N., Lawley, R.S., Rushton, A.W.A. 1998. Geology of the Country around Coventry and Nuneaton. Memoir for 1:50 000 Geological Sheet 169 (England and Wales). British Geological Survey, Nottingham.

Brodie, J., White, N.J., 1994. Sedimentary basin inversion caused by igneous underplating: Northwest European continental shelf. Geology 22, 147-150.

Bullard, E.C., Gaskell, T.F., Harland, W.B., Kerr-Grant, C. 1940. Seismic investigations on the Palaeozoic floor of East England. Philosophical Transactions of the Royal Society, London, Series A, 239, $29-95$.

Busby, J.P., Kimbell, G.S., Pharaoh, T.C. 1993. Integrated geophysical/geological modelling of the Caledonian and Precambrian basement of southern Britain. Geological Magazine 130, 593-604

Butler, A.J., Woodcock, N.H., Stewart, D.M. 1997. The Woolhope and Usk Basins: Silurian rift basins revealed by subsurface mapping of the southern Welsh Borderland. Journal of the Geological Society, London 154, 209-223.

Butler, M. 2017 (in press). Palaeozoic sequences of the Midlands Microcraton.. In: Monaghan, A.A., Underhill, J.R.,

Marshall, J.E.A. \& Hewett, A. (Eds). Palaeozoic Plays of NW Europe. Special Publication 465, Geological Society of London. Cameron, T.D.J., Crosby, A., Balson, P.S., Jeffrey, D.H., Lott, G.K., Bulat, J., Harrison, D.J., 1992. United Kingdom offshore regional report: the geology of the southern North Sea. (HMSO, London for the British Geological Survey, Nottingham)

Campbell, S.D.G., Howells, M.F., Smith, M., Reedman, A.J. 1988. A Caradoc failed-rift within the Ordovician marginal basin of Wales. Geological Magazine 125, 257-266.

Carney, J.N. 1994. Geology of the Thringstone, Shepshed and Loughborough districts (SK41NW, SK41NE and SK51NW). British Geological Survey, Nottingham Technical Report WA/94/08.

Carney, J.N. 1995. Precambrian and Lower Cambrian rocks of the Nuneaton Inlier: A field excursion to Boon's and Hartshill quarries. Mercian Geologist 13, 189-198.

Carney, J.N., Ambrose, K. 2017. A window into the Cambrian basement and early Carboniferous sedimentation of the Hathern Shelf: the British Geological Survey borehole atTicknall, South Derbyshire, UK. Proceedings of the Yorkshire Geological Society 70,

Carney, J.N., Pharaoh, T. C. 1993. Geology and structure of Precambrian rocks in quarries north-west of Nuneaton. British Geological Survey, Nottingham Technical Report WA/93/94.

Carney, J.N., Pharaoh, T.C. 1999. Chapter 8 Central England. In: D.Stephenson, D., Bevins, R.E. Millward, D., Stone, P., Parsons, J., Highton, A.J., Wadsworth, W.J. Caledonian Igneous Rocks of Great Britain. Geological Conservation Review Volume 17, Joint Nature Conservation Committee-Chapman and Hall, 650 pp.

Carney, J.N., Alexandre, P., Pringle, M.S., Pharaoh, T.C., Merriman, R.J, Kemp, S.J. 2008. ${ }^{40} \mathrm{Ar} /{ }^{39} \mathrm{Ar}$ constraints on the age of deformational fabrics in Charnwood Forest, UK. Geological Magazine 145, 702-713.

Carney, J.N., Glover, B.J., Pharaoh, T.C. 1992. Pre-conference field excursion guide: Midlands. British Geological Survey, Nottingham Technical Report WA/92/72, 28pp.

Cazes, M, Toreilles, G. 1988. (Eds.). Étude de la croûte terrestre par sismique profonde; profile Nord de la France. Editions Technip: Paris.

Chacksfield, B, De Vos, W., D'hooge, L., Dusar, M., Lee, M., Poitevin, C, Royles, C., Verniers, J. 1993. A new look at Belgian aeromagnetic and gravity data through image-based display and integrated modelling techniques. Geological Magazine 130, 583-591.

Chadwick, R.A.1985. Seismic reflection investigations into the stratigraphy and structural evolution of the Worcester Basin. Journal of the Geological Society, London 142, 187-202.

Chadwick, R.A. 1986. Extension tectonics in the Wessex Basin, southern England. Journal of the Geological Society, London $143,465-488$

Chadwick, R.A., Evans, D.J. 2005. A seismic atlas of southern Britain - images of subsurface structure. Occasional Publication No. 7, 193pp. British Geological Survey, Nottingham,

Chadwick, R.A., Pharaoh, T.C. 1996. Seismotectonics of the UK. Final Report. Main Text plus appendices A, B and D. BGS Technical Report WA/96/3C: Issue 1.0. 54 pp plus Figures and 96 Enclosures.

Chadwick, R.A., Pharaoh, T.C. 1998. The seismic reflection Moho beneath the United Kingdom and adjacent areas. Tectonophysics 299, 255-279.

Chadwick, R.A., Smith, N.J.P. 1988. Evidence of negative structural inversion beneath central England from new seismic data. Journal of the Geological Society, London 145, 519-522.

Chadwick, R.A., Kenolty, N., Whittaker, A., 1983. Crustal structure beneath southern England from deep seismic reflection profiles. Journal of the Geological Society, London 140, 893-911.

Chadwick, R.A., Livermore, R.A., Penn, I.E. 1989. Continental extension in Southern Britain and surrounding areas and its relationship to the opening of the North Atlantic Ocean. In; Tankard, A.J., Balkwill, H.R. (Eds.). Extensional Tectonics and Stratigraphy of the North Atlantic Margins. American Association of Petroleum Geologists Memoir 46, pp. 411-424.

Chadwick, R.A., Pharaoh, T.C., Smith, N.J.P. 1989. Lower crustal heterogeneity beneath Britain from deep seismic reflection data. Journal of the Geological Society, London 146, 617-630.

Chaloner, W.G., Richardson, J.B.1977. South-east England. In: House, M.R. (Ed.). A correlation of the Devonian rocks of the British Isles. Special Report of the Geological Society, London 8. pp.26-40.

Chisholm, J.I., Hallsworth, C. R. 2005. Provenance of Upper Carboniferous sandstones in east Derbyshire: role of the Wales-Brabant High. Proceedings of the Yorkshire Geological Society 55, 209-233.

Chisholm, J.I., Charsley, T. J., Aitkenhead, N. 1988. Geology of the country around Ashbourne and Cheadle. Memoir of the British Geological Survey, Nottingham, Sheet 124 (England and Wales). 
Chroston, P.N., Allsop, J.M., Cornwell, J.D. 1987. New seismic refraction evidence on the origin of the Bouguer anomaly low near Hunstanton, Norfolk. Proceedings of the Yorkshire Geological Society 46, 311-319.

Cocks, L.R.M. 2002. Key Lower Palaeozoic faunas from near the Trans-European Suture Zone. In: Winchester, J.A., Pharaoh, T.C., Verniers, J. (Eds.). Palaeozoic Amalgamation of Central Europe. Geological Society, London. Special Publications 201, pp. 37-46.

Cocks, L.R.M, Fortey, R.A. 1982. Faunal evidence for oceanic separations in the Palaeozoic of Britain. Journal of the Geological Society, London 139, 465-478.

Cocks, L.R.M, Fortey, R.A. 2009. Avalonia: a long-lived terrane in the Lower Palaeozoic. In: Bassett, M.G. (Ed.). Early Palaeozoic Peri-Gondwanan Terranes: New Insights from Tectonics and Biogeography.

Cocks, L.R.M., McKerrow, W.S., Van Staal, C.R. 1997. The margins of Avalonia. Geological Magazine 134, 627-636.

Cocks, L.R.M., Holland, C.H., Rickards, R.B., Strachan, I. 1971. A correlation of Silurian rocks in the British Isles. Special Report of the Geological Society, London 1.

Cocks, L.R.M, Torsvik, T. 2006. European geography in a global context from the Vendian to the end of the Palaeozoic. In: Gee, D.G.and Stephenson, R.A. (Eds). European Lithosphere Dynamics. Geological Society, London Memoir 32, 83-95.

Cocks, L.R.M., McKerrow, W.S., Van Staal, C.R. 1997. The margins of Avalonia. Geological Magazine, 134, 627-636. Geological Society, London. Special Publications 325, 141-155.

Cocks, L.R.M., Holland, C.H., Rickards, R.B. 1992. A revised correlation of Silurian rocks in the British Isles. Special Report of the Geological Society, London 21.

Collins, A.S., Buchan, C. 2004. Proveanance and age constraints of the South Stack Group, Anglesy, UK: U-Pb SIMS detrital zircon data. Journal of the Geological Society, London 161, 743-746.

Collinson, J.D. 1988. Controls on Namurian sedimentation in the Central Province basins of northern England. In: Besly, B., Kelling, G (Eds.).Sedimentation in a synorogenic basin complex: the Upper Carboniferous of northwest Europe. pp.85100. Blackie, London and Glasgow.

Colman-Sadd, S. P., Dunning, G. R., Dec, T. 1992. Dunnage-Gander relationships and Ordovician orogeny in central Newfoundland: a sediment provenance and U/Pb study. American Journal of Science 292, 317-355.

Compston, W., Wright, A.E., Toghill, P. 2002. Dating the Late Precambrian volcanicity of England and Wales. Journal of the Geological Society, London 159, 323-339.

Coney, P.J., Jones, D.L., Monger, J.W.H. 1980. Cordilleran suspect terranes. Nature 288, 329-333.

Cooper, A.H., Millward, D., Johnson, E.W. et al. 1993. The early Palaeozoic evolution of northwest England. Geological Magazine 130, 711-24.

Cope, F.W. 1973. Woo Dale borehole near Buxton, Derbyshire. Nature, Physical Science 243, 29-30.

Cope, F.W. 1979. The age of the volcanic rocks in the Woo Dale borehole, Derbyshire. Geological Magazine 116, 319-320.

Cope, J.C.W., Ingham, J.K., Rawson, P.F. 1992. Atlas of Palaeogeography and Lithofacies. Geological Society, London.Memoir 13.

Cope, J.C.W., Guion, P.D., Sevastopulo, G.D., Swan, A.R.H.1992. Carboniferous. In: Cope, J.C.W., Ingham, J.K., Rawson, P.F. (Eds.) Atlas of Palaeogeography and Lithofacies. Memoir of the Geological Society, London 13, 153pp.

Corfield, S M, Gawthorpe, R L, Gage, M, Fraser, A J, Besly, B M. 1996. Inversion tectonics of the Variscan foreland of the British Isles. Journal of the Geological Society, London. 153, 17-32.

Cornwell, J.D., Walker, A.S.D. 1989. Chapter 4. Regional Geophysics. In: Plant, J.A., Jones, D.G. (Eds.). Metallogenic models and exploration criteria for buried carbonate-hosted ore deposits-a multidisciplinary study in eastern England, pp. 2552. The Institution of Mining and Metallurgy, London and British Geological Survey, Nottingham, 161pp.

Cowie, J.W., Rushton, A.W.A., Stubblefield, C.J. 1972. A correlation of Cambrian rocks in the British Isles. Geological Society, London. Special Reports, 2.

Currie, K.L., van Breeman, O., Hunt, P.A., van Berkel, J.T. 1991. Age of high-grade gneisses south of Grand Lake, Newfoundland. Atlantic Geology 28, 153-161

D’Lemos, R.S., Strachan, R.A., Topley, C.G. (Eds.) 1990. The Cadomian Orogeny. Geological Society, London.Special Publication 51, 423 pp.

Dalziel, I.W.D. 1991. Pacific margins of Laurentia and East Antarctica-Australia as a conjugate rift pair: Evidence and implications for an Eocambrian supercontinent. Geology 19, 598-601.

Dalziel, I.W.D. 1997. Neoproterozoic-Paleozoic geography and tectonics: Review, hypothesis, environmental speculation. Geological Society of America, Bulletin 109, 16-42.

Davies, S.J., Guion, P.D., Gutteridge, P. 2012. Chapter 14. Carboniferous Sedimentation and Volcanism on the Laurussian Margin. In: Woodcock, N.H., Strachan, R.A. 2012. (Eds.). Geological History of Britain and Ireland. Blackwell Publishing Ltd., Oxford. 2nd ed. 442pp.

De Vos, W. 1997. Influence of the granitic batholith of Flanders on Acadian and later deformation (Brabant Massif, Belgium). Aardkundige Mededelingen 8, 49-52.

De Vos, W., Verniers, J., Herbosch, A., Vanguestaine, M. 1993. A new geological map of the Brabant Massif, Belgium. Geological Magazine 130, 605-611.

De Vos, W., Feldrappe, H., Pharaoh, T.C., Smith, N., Vejbæk, O., Verniers, J., Nawrocki, J., Poprawa, P., Bełka, Z. 2010. Chapter 4. Pre-Devonian. In: Doornenbal, J.H., Stevenson, A.G. (Eds.). Petroleum Geological Atlas of the Southern Permian Basin. pp59-70. EAGE, Houten.

Dearnley, R. 1966. Ignimbrites from the Uriconian and Arvonian. Bulletin of the Geological Survey of Great Britain 24, $1-6$.

Debacker, T. N, Sintubin, M., Verniers, J. 2001. Large-scale slumping deduced from structural relations and sedimentary features: a study in the Lower Palaeozoic Anglo-Brabant fold belt, Belgium. Journal of the Geological Society, London 158, 341-352. 
Debacker, T.N., Dewaele, S., Sintubin, M., Verniers, J., Sintubin, M. 2005. Timing asnd duration of the progressive deformation of the Brabant Massif, Belgium. Geologica Belgica 8, 20-34.

Debacker, T., Herbosch, A. 2011. Field guide to the pre-cleavage deformation and stratigraphy of the Jodoigne area. Memoirs of the Geological Survey of Belgium 57, 1-27.

Dewaele, S., Boven, A., Muchez, P. 2002. ${ }^{40} \mathrm{Ar} /{ }^{39} \mathrm{Ar}$ dating of mesothermal, orogenic mineralisation in a low-angle reverse shear zone in the Lower Palaeozoic of the Anglo-Brabant fold belt, Belgium. Transactions of the Institute of Mining and Metallurgy 111, B215-220.

Dewey, J.F. 1969. Evolution of the Appalachian-Caledonian Orogen. Nature 222, 124-128.

Dewey, J. F. 1982. Plate tectonics and the evolution of the British Isles. Journal of the Geological Society, London 139, 371-412.

Dewey, J. F., Strachan, R.A. 2003. Changing Silurian-Devonian relative plate motion in the Caledonides: sinistral transpression to sinistral transtension. Journal of the Geological Society, London 160, 219-229.

Donato, J.A., Martindale, W., Tully, M.C. 1983. Buried granites within the Mid North Sea High. Journal of the Geological Society, London 140, 825-837.

Donato, J.A., Megson, J.B. 1990. A buried granite batholith beneath the East Midland Shelf of the Southern North Sea Basin. Journal of the Geological Society, London 147, 133-140.

Doornenbal, J.H., Stevenson, A.G. (Eds.). Petroleum Geological Atlas of the Southern Permian Basin. EAGE, Houten.

Dumont, A. 1847. Mémoire sur les terrains ardennais et rhénan de l'Ardenne, du Rhin, du Brabant et du Condroz. Mémoires de l'Académie Royale de Belgique, Classe des Sciences 20,1-163.

Dunham, K C. 1973. A recent deep borehole near Eyam, Derbyshire. Nature, Physical Sciences 241, 84-85.

Dunning, F.W. 1975. Precambrian Craton of central England and the Welsh Borders. In: Harris, A.L. and five others (Eds.) A correlation of Precambrian rocks in the British Isles. Pp 83-95. Special Report, Geological Society, London 6.

Dunning, G R.,O' Brien, S.J. 1989. Late Proterozoic-Early Paleozoic crust in the Hermitage flexure, Newfoundland Appalachians: $\mathrm{U} / \mathrm{Pb}$ ages and tectonic significance. Geology 17, 548-551.

Eastwood, T. 1935. British regional geology: northern England (first edition). HMSO, London for the Institute of Geological Sciences.

Ebdon, C.C., Fraser, A.J., Higgins, A.C., Mitchener, B.C., Strank, A.R.E., 1990. The Dinantian stratigraphy of the East Midlands: a seismostratigraphic approach. Journal of the Geological Society, London 147, 519-536.

Edwards, W.N. 1967. Geology of the Country around Ollerton. Memoir of the Geological Survey of Great Britain.

Ellison, R.A., Woods, M.A., Allen, D.J., Forster, A., Pharaoh, T.C., King, C. 2004. Geology of London. Special Memoir for 1: 50000 Gelogical sheets 256 (North London), 257 (Romford), 270 (South London) and 271 (Dartford). (England and Wales). British Geological Survey, Keyworth, Nottingham.

England, R. 1995. The Seismic signatures of the Iapetus Suture beneath the North Sea. Studia Geophysica \& Geodætica $39,235-240$

England, R., Hobbs, R., Maguire, P.K.H., Abramowitz, T., Berthelsen, A., Schjoth, F., Thybo, H., Balling, N., Nielsen, L., Flueh, E.R., Huebinger, S., Reston, T., Pedersen, L.B., Schmidt, J. 1997. Closure of the Tornquist Sea: constraints from MONA LISA deep seismic reflection data. Geology 25, 1071-1074.

Evans, J.A. 1989. Resetting of the Rb-Sr whole-rock isotope system of an Ordovician microgranite during Devonian low-grade metamorphism. Geological Magazine 126, 675-679.

Falcon, N. L., Kent, P. E. 1960. The Geological results of petroleum exploration in Britain. 1945-1957. Geological Society, London 56 pp. Memoir 2.

Ford, T.D. 1958. Precambrian fossils from Charnwood Forest. Proceedings of the Yorkshire Geological Society 31, 211-217.

Fortey, N.J., Merriman, R.J., Huff, W.D. 1996. Silurian and late Ordovician K-bentonites as a record of late Caledonian volcanism in the British Isles. Transactions of the Royal Society of Edinburgh 86, 167-180.

Fortey, R.A., Cocks, L.R.M. 1988. Arenig to Llandovery faunal distributions in the Caledonides. in: Harris, A.L., Fettes, D.J.(Eds.) The Caledonian-Appalachian Orogen. Special publication 38, Geological Society, London.

Fortey, R. A., Cocks, L. R. 2003. Palaeontological evidence bearing on global Ordovician-Silurian continental reconstructions. Earth Science Reviews 61, 245-307.

Fortey, R.A., Harper, D.A.T., Ingham, J.K., Owen, A.W., Parkes, M.A., Rushton, A.W.A., Woodcock, N.H. 2000. A revised correlation of Ordovician Rocks in the British Isles. Special Report 24, Geological Society, London.

Foster, D., Holliday, D.W., Jones, C.M., Owens, B., Welsh, A. 1989. The concealed Upper Palaeozoic rocks of Berkshire and South Oxfordshire. Proceedings of the Geological Association of London 100, 395-407.

Franke, D., 1995. The Caledonian Terranes at the Southwestern Border of the East European Platform - Evidences, Speculations and Open Questions. In: Gee, D.G., Beckholmen, M. (Eds.), The Trans-European Suture Zone: EUROPROBE in Liblice 1993. Studia Geophysica et Geodaetica 39, 241-257.

Franke, W., Cocks, L.R.M., Torsvik, T. 2017. The Palaeozoic Variscan oceans revisited. Gonwana Research 48, 257-284.

Fraser, A.J., Nash, D.F., Steele, R.P., Ebdon, C.C. 1990. A regional assessment of the intra-Carboniferous play of northern England. Brooks, J. (Ed.). Classic Petroleum Provinces. Geological Society, London pp. 417-439. Special Publication 50..

Fraser, A.J., Gawthorpe, R.L. 2003. An Atlas of Carboniferous Basin Evolution in Northern England. Geological Society, London. 79pp. Memoir No. 28.

Frost, R.T.C., Fitch, F.J, Miller, J.A. 1981. The Age Nature of the Crystalline Basement of the North Sea Basin. In: Illing, L.V., Hobson, G.D. (Eds.), Petroleum Geology of the Continental Shelf of North-West Europe. pp.43-57. Institute of Petroleum, London.

Fulton, I. M., Williams, H. 1988. Palaeogeographical change and controls on Namurian and Westphalian A/B sedimentation at the southern margin of the Pennine Basin, central England. 178-199. In: Besly, B. M., Kelling, G (Eds.).Sedimentation in a synorogenic basin complex: the Upper Carboniferous of northwest Europe. Blackie, Glasgow and 
London.

Fyffe, L. R , Barr, S. M., Johnson, S. C., McLeod, M. J., McNicoll, V., Valverde-Vaquero, P. , van Staal, C. R., White, C. E. , 2009. Detrital zircon ages from Neoproterozoic and Early Paleozoic conglomerate and sandstone units of New Brunswick and coastal Maine: implications for the tectonic evolution of Ganderia. Atlantic Geology 45, 110-144.

Gawthorpe, R. L., Gutteridge, P., Leeder, M. R. 1989. Late Devonian and Dinantian basin evolution in northern England and north Wales. p1-23. In: Arthurton, R. S., Gutteridge, P., Nolan, S. C. (Eds.)The role of tectonics in Devonian and Carboniferous sedimentation in the British Isles. Yorkshire Geological Society, Occasional Publication, No. 6.

Gee, D.G.and Stephenson, R.A. (Eds). European Lithosphere Dynamics. Geological Society, London Memoir 32.

Gee, D.G., Zeyen, H. 1996. EUROPROBE 1996 - Lithosphere Dynamics - Origin and Evolution of Continents. EUROPROBE Secretariat, Uppsala 138pp.

George, T.N. 1958. Lower Carboniferous palaeogeography of the British Isles. Proc. Yorks. Geol. Soc. 31, 227-318.

George, T.N., 1970. British Regional Geology: South Wales. Third Edition. (London: HMSO).

Gibbons, W. 1987. The Menai Strait Fault system: an early Caledonian terrane boundary in North Wales. Geology 15, 744-747.

Gibbons, W. 1990. Transcurrent ductile shear zones and the dispersal of the Avalon Superterrane In: D’Lemos, R.S., Strachan, R.A., Topley, C.G. (Eds.) 1990. The Cadomian Orogeny. Geological Society, London. Special Publications 51, $407-$ 423.

Gibbons, W, Horák, J.M. 1996. The evolution of the Neoproterozoic Avalonian subduction system: Evidence from the British Isles, in Avalonian and Related Peri-Gondwana Terranes of the Circum-Atlantic. In: R.D. Nance, M.D. Thompson (Eds.), Geological Society of America Special Paper 304, pp 269-280.

Gibbons, W., Harris, A.L. et al. 1994. A revised correlation of Precambrian rocks in the British Isles. In: Gibbons, W., A.L. Harris (Eds.). Geological Society, London Special Report No.22.

Gibbons, W., Tietzsch-Tyler, D, Horák, J.M., Murphy, F. 1994. Precambrian rocks in Anglesey, southwest Llyn and southeast Ireland, In: Gibbons, W., Harris, A.L. (Eds.). A Revised Correlation of Precambrain rocks in the British Isles, Geological Society, London. pp 75-84. Special Report No.22.

Glover, B. W., Powell, J. H. 1996. Interaction of climate and tectonics upon alluvial architecture: late CarboniferousEarly Permian sequences at the southern margin of the Pennine Basin, UK. Palaeogeography, Palaeoclimatology, Palaeoecology 121, 13-34.

Gradstein, F.M., Ogg, J.G, Schmitz, M., Ogg, C., 2012. The Geologic Time Scale. Elsevier and the Geologic TimeScale Foundation website: https://engineering.purdue.edu/stratigraphy.

Greig, D. C., Wright, J. E., Hains, B. A., Mitchell, G. H. 1968. Geology of the country around Church Stretton, Craven Arms, Wenlock Edge and Brown Clee. Memoir of the British Geological Survey, Nottingham, Sheet 166 (England and Wales).

Groom, T.T. 1902. Geology of Malvern. Quarterly Journal of the Geological Society, London 58, 89.

Hallsworth, C. R., Chisholm, J. I. 2000. Stratigraphic evolution of provenance characteristics in Westphalian sandstones of the Yorkshire Coalfield. Proceedings of the Yorkshire Geological Society 53, 43-72.

Hallsworth, C.R., Chisholm, J.I. 2008. Provenance of late Carboniferous sandstones in the Pennine Basin (UK) from combined heavy mineral, garnet geochemistry and palaeocurrent studies. Sedimentary Geology 203, 196-212.

Hallsworth, C.R., Chisholm, J.I. 2017. Interplay of mid-Carboniferous sediment sources on the northern margin of the Wales-Brabant High. Proceedings of the Yorkshire Geological Society 70, 285-309.

Hallsworth, C.R., Morton, A.C., Claoué-Long, J., Fanning, C.M. 2000. Carboniferous sand provenance in the Pennine Basin, UK: constraints from heavy mineral and detrital zircon age data. Sedimentary Geology 137, 147-185.

Hancock, J.M., Rawson, P.F. 1992. Cretaceous. In: Cope, J.C.W., Ingham, J.K., Rawson, P.F. (Eds.). Atlas of Palaeogeography and Lithofacies. Geological Society, London. pp 131-139.

Hamblin, R.J.O., Crosby, A., Balson, P.S., Jones, S.M., Chadwick, R.A., Penn, I.E., Arthur, M.J., 1992. United Kingdom offshore regional report: the geology of the English Channel. (HMSO, London for the British Geological Survey, Nottingham).

Harper, D.A.T., Parkes, M.A., 1989. Palaeontological constraints on the definition and development of the Irish Caledonides. Journal of the Geological Society, London 146, 413-415.

Harper, D.A.T., Owen, A.W., Bruton, D. L., 2009. Ordovician life around the Celtic fringes: diversifications, extinctions and migrations of brachiopod and trilobite faunas at middle latitudes .In: Basset M. G. (Ed.) Early Paleozoic Gondwanan terranes: new insights from tectonics and biogeography. Geological Society, London. Special Publication 325, 157-170.

Harper, D.A.T., Parkes, M.A., Hoey, A.N., Murphy, F.C. 1990. Intra-Iapetus brachiopods from the Ordovician of eastern Ireland: implications for Caledonide correlation. Canadian Journal of Earth Sciences 27, 1757-1761.

Harrison, R.K. 1974. Sidewall slices from Ultramar Well, Netherton. Unpublished Petrography Dept. Report, Geological Survey of Great Britain.

Herbosch, A., Verniers, J. 2002. The Lower Palaeozoic stratigraphy and sedimentology of the Brabant Massif in the Dyle and Orneau valleys and of the Condroz inlier at Fosses: an excursion guidebook. Geologica Belgica 5, 71-143.

Herbosch, A., Verniers, J. 2011. What is the biostratigraphic value of the ichnofossil Oldhamia for the Cambrian: a review. Geologica Belgica 14, 229-248.

Herbosch, A., Verniers, J. 2013. Stratigraphy of the Lower Palaeozoic of the Brabant Massif, Belgium. Part I: The Cambro-Ordovician from the Halle and Ottignies groups. Geologica Belgica 16, 49-65.

Herbosch, A., Verniers, J. 2014. Stratigraphy of the Lower Palaeozoic of the Brabant Massif, Belgium. Part II: The Middle Ordovician to lowest Silurian of the Rebecq Group. Geologica Belgica 17, 115-136.

Hoffman, P., Dewey, J.F., Burke, K.A.C. 1974. Aulacogens and their genetic relation to geosynclines with a Proterozoic example from Great Slave Lake, Canada. In: Dott, R.H., Shaver, R.H. (Eds.). Modern and ancient geosynclinal sedimentation. Society of Economic Palaeontologists and Mineralogists , pp.38-5. Special Publication 19.

Holder, M.T., Leveridge, B. E. 1986. Correlation of the Rhenohercynian Variscides. Journal of the Geological Society, London 143, 141-147. 
Holgate, N., Hallowes, K.A.K. 1941. The igneous rocks of the Stanner-Hanter District, Radnorshire. Geological Magazine 78, 241-267.

Horák, J.M., Doig, R., Evans, J.A., Gibbons, W. 1996. Avalonian magmatism and terrane linkage: new isotopic data from the Precambrian of North Wales, Journal of the Geological Society, London 153, 91-99.

Howells, M.F., Reedman, A.J., Campbell, S.D.G.1990. Ordovician Marginal Basin volcanism in Snowdonia (N.W.Wales). Book Series, British Geological Survey, Nottingham.

Huff, W.D., Kolata, D.R., Bergstrom, S.M., Zhang, Y.S. 1996. Large-magnitude Middle Ordovician volcanic ash falls in North America and Europe: dimensions, emplacement and post-emplacement characteristics. Geology 20, 875-878.

Hughes, R.A., Cooper, A.H., Stone, P. 1993. Structural evolution of the Skiddaw Group (English Lake District) on the northern margin of eastern Avalonia. Geological Magazine 130, 621-629.

Hughes, R.A., Evans, J.A., Noble, S.R., Rundle, C.C. 1996. U-Pb chronology of the Ennerdale and Eskdale intrusions supports sub-volcanic relationships with the Borrowdale Volcanic Group (Ordovician, English Lake District). Journal of the Geological Society, London 153, 33-38.

James, J. H. 1956. The structure and stratigraphy of part of the Pre-Cambrian outcrop between Church Stretton and Linley, Shropshire. Quarterly Journal of the Geological Society, London 112, 315-337.

Jones, C. M. 1980. Deltaic sedimentation in the Roaches Grit and associated sediments (Namurian R2b) in the south-west Pennines. Proceedings of the Yorkshire Geological Society 43, 39-67.

Kelly, A., England, R.W., Magguire, P.K.H. 2007. A crustal seismic velocity model for the UK, Ireland and surrounding seas. Geophysical Journal International 140, 660-676.

Kent, P.E., 1947. A deep boring at North Creake, Norfolk. Geological Magazine 84, 2-18.

Kent, P.E., 1962. A borehole to basement rocks at Glinton, near Peterborough, Northants. Proceedings of the Geologists' Association, London.1595, 40-42.

Kent, P. 1966. The Structure of the Concealed Carboniferous Rocks of North Eastern England. Proc. Yorks. Geol. Soc. 35,323 .

Kent, P. 1967. A contour map of the sub-Carboniferous surface in the north-east Midlands. Proceedings of the Yorkshire Geological Society 36, 127-133.

Kent. P.E., 1968. The Buried Floor of Eastern England. In: Ford, T.D., Sylvester-Bradley, P.C. (Eds.). Geology of the East Midlands. Leicester University Press. 400 pp.

Keppie, J.D., Davis, D.W., Krogh, T.E. 1998. U-Pb geochronological constraints on Precambrian stratified units in the Avalon Composite terrane of Nova Scotia, Canadian Journal of Earth Sciences 35, 222-236.

Kirby, G.A., Aitkenhead, N., Baily, H.E., Birch, B., Evans, D.J., Holliday, D.W., Holloway, S., Hulbert, A.G., Pharaoh, T.C., Smith, N.J.P. 2000. The structure and evolution of the Craven Basin and adjacent areas. Subsurface Memoir, British Geological Survey, Nottingham, 130pp.

Klemperer, S., Hobbs, R. 1991. The BIRPS Atlas: deep seismic reflection profiles around the British Isles. Cambridge University Press.

Kneller, B.C. 1991. A foreland basin on the southern margin of Iapetus. Journal of the Geological Society, London 148, 207-210.

Kneller, B.C., King, L.M., Bell, A.M. 1993. Foreland basin development and tectonics on the northwest margin of eastern Avalonia. Geological Magazine 130, 691-697.

Kokelaar, B.P. 1986. Petrology and geochemistry of the Rhobell Volcanic Complex: amphibole dominated fractionation at an early Ordovician arc volcano in North Wales. Journal of Petrology 27, 887-914.

Kokelaar, B.P. 1988. Tectonic controls of Ordovician arc and marginal basin volcanism in Wales. Journal of the Geological Society, London 145, 759-775.

Kokelaar, B.P., Howells, M.F., Bevins, R.E., Roach, R.A., Dunkley, P.N. 1984. The Ordovician marginal basin of Wales. In: Kokelaar, B.P., Howells, M.F. (Eds.) Marginal Basin Geology: volcanic and associated sedimentary and tectonic processes in modern and ancient marginal basins. Geological Society, London. Special Publication 16, 322pp

Krogh, T.E., Strong, D.F., O'Brien, S.J., Papezik, V.S. 1988. Precise U-Pb zircon dates from the Avalon Terrane in Newfoundland. Canadian Journal of Earth Sciences 25, 442-453.

Lamplugh, G.W. Hill, J.B. Gibson, W. Sherlock, R.L. Smith, B. Geological Survey of Great Britain. 1911. The geology of the country around Ollerton. Explanation of sheet 113. (Memoir (Sheet) Geological Survey of GB (England, Wales) - New Series; 113) (London: HMSO)

Lancaster, P.J., Daly, J.S., Stoprey, C.G., Morton, A.C. 2017. Interrogating the provenance of large river systems: multi-proxy in situ analyses in the Millstone Grit, Yorkshire. Journal of the Geological Society, London 174, 75-87.

Landing, E. 1996. Avalon - insular continent by the latest Precambrian. In: Nance, R.D., Thompson, M. (Eds.). Avalonian and Related Peri-Gondwanan Terranes of the Circum-North Atlantic. Geological Society of America Special Paper

Landing, E. 2005.Early Palaeozoic Avalon-Gondwana unity: an obituary. Response to "Palaeontological evidence bearing on global Ordovician-Silurian continental reconstructions" by R.A.Fortey, L.R.M. Cocks. Earth-Science Reviews 69, 169-175.

Landing, E., Westrop, S.R., Bowring, S.A. 2013. Reconstructing the Avalonia palaeocontinent in the Cambrian: A 519 Ma caliche in South Wales and transcontinental middle Terrneuvian sandstones. Geological Magazine 150,

Leat, P.T., Thorpe, R.S. 1989. Snowdon basalts and the cessation of Caledonian subduction by the Longvillian. Journal of the Geological Society, London 146, 965-970.

Leat, P.T., Jackson, S.E., Thorpe, R.S., Stillman, C.J. 1986. Geochemistry of bimodal basalt- subalkaline/peralkaline rhyolite provinces within the southern British Caledonides. Journal of the Geological Society, London 143, 259-273.

Le Bas, M.J. 1968. Caledonian Igneous Rocks. In: Ford, T.D., Sylvester-Bradley, P. C. (Eds.). Geology of the East Midlands. Leicester University Press. 400 pp.

Le Bas, M.J. 1972. Caledonian igneous rocks beneath central and eastern England. Proceedings of the Yorkshire Geological Society 39, 71-86. 
Le Bas, M.J. 1982. Geological evidence from Leicestershire on the crust of southern Britain. Transactions of the Leicester Literary and Philosophical Society 76, 54-67.

Lee, J.R., Woods, M.A., Moorlock, B.S.P. 2015. (Eds). British Regional Geology: East Anglia (Fifth edition). British Geological Survey, Nottingham.

Lee, M.K., Pharaoh, T.C., Green, C.A. 1991. Structural trends in the concealed Caledonide basement of eastern England from images of regional potential field data. In: André, L., Herbosch, A., Vanguestaine, M., Verniers, J. (Eds.).Proceedings of the International Meeting on the Caledonides of the Midlands and the Brabant Massif. Annales de la Société Géologique de Belgique 114, 45-62.

Lee, M.K., Pharaoh, T.C., Soper, N.J. 1990. Structural trends in central Britain from images of gravity and aeromagnetic fields. Journal of the Geological Society, London 147, 241-258.

Lee, M.K., Pharaoh, T.C, Williamson, J. P., Green, C.A., De Vos, W., 1993. Evidence on the deep structure of the AngloBrabant Massif from gravity and magnetic data. Geological Magazine 130, 575-582.

Lees, G.M., Taitt, A.H. 1945. The geological results of the search for oil in Great Britain. Quarterly Journal of the Geological Society, London 101, 255.

Legrand, R. 1968. Le Massif du Brabant. Mémoires pour servir à l'Explication des Cartes Géologiques et Minières de la Belgique, Mémoire 9, 1-48.

Leveridge, B.E., Holder, M.T., Day, G.A. 1984. Thrust nappe tectonics in the Devonian of south Cornwall and the western English Channel. In: Hutton, D.W., Sanderson, D.J. (Eds.). Variscan Tectonics of the North Atlantic Region. Geological Society, London. Special Publications 14, 103-112.

Linnemann, U., Herbosch, A., Liégois, J-P., Pin, C., Gärtner, A., Hofmann, 2012. The Cambrian to Devonian odyssey of the Brabant Massif within Avalonia: A review with new zircon ages, geochemistry, Sm-Nd isotopes, stratigraphy and palaeogeography. Earth-Science Reviews 112, 126-154. .

Lister, T.R., Cocks, L.R.M., Rushton, A.W.A., 1969. The basement beds in the Bobbing borehole, Kent. Geological Magazine 106, 601-603.

Lynas, B.D.T. 1988. Evidence for dextral oblique-slip faulting in the Shelve Ordovician inlier, Welsh Borderland: implications for the south British Caledonides. Geological Journal 23, 39-57.

Lyngsie, S., Thybo, H. 2006. A new tectonic model for the Laurentia-Avalonia-Baltica sutures in the North Sea: A case study along MONA LISA profile 3. Tectonophysics 429, 201-227.

Maguire, P. K. H. 1987. Charm II: a deep reflection profile within the central England microcraton. Journal of the Geological Society, London 144. 661-670

Maguire, P., England, R., Hardwick, A. 2011. LISPB DELTA, a lithospheric seismic profile in Britain: analysis and interpretation of Wales and southern England section. Journal of the Geological Society, London 168, 61-82.

Matte, P. 2001. The Variscan collage and orogeny (480-290 Ma) and the tectonic definition of the Armorica microplate: a review. Terra Nova 13, 123-128. 218.

McConnell, B., Morris, J. 1997. Initiation of Iapetus subduction under Irish Avalonia. Geological Magazine 134, 213-

McIlroy, D., Horak, J. 2006. Neoproterozoic: the late Precambrian terranes that formed Eastern Avalonia. In: Brenchley, P.J., Rawson, P.F. (Eds.). The Geology of England and Wales. The Geological Society, London. 2 nd ed.

McIlroy, D., Brasier, M.D., Moseley, J.M. 1998. The Proterozoic-Cambrian transition within the 'Charnian Supergroup' of central England and the antiquity of the Ediacara fauna. Journal of the Geological Society, London 155, 401-413.

McKerrow, W.S., Dewey, J.F., Scotese, C.R. 1990. The Ordovician and Silurian development of the Iapetus Ocean. In: Bassett, M.G., Lane, P.D., Edwards, D. (Eds). The Murchison Symposium. Special Papers in Palaeontology 42.

McKerrow, W.S., Lambert, R.J., Cocks, L.R.M. 1985. The Ordovician, Silurian and Devonian periods. In: Snelling, N.J. (Ed.). Geochronology and the Geological Record. Geological Society, London. Memoir 10, pp73-80.

Mechie, J., Brooks, M. 1984. A seismic study of deep geological structure in the Bristol Channel area, SW Britain. Geophysical Journal of the Royal Astronomical Society 78, 661-689.

Meissner, R., Bortfeld, R.K. 1990. (Eds.). DEKORP Atlas: results of the Deutsches Kontinentales Reflexions-seismisch Programm. Springer-Verlag, Berlin and Heidelberg.

Merriman, R.J., Kemp, S.J. 1997. Metamorphism of the Charnian Supergroup in the Loughborough District, 1:50k Sheet 141. British Geological Survey, Nottingham Technical Report WG/97/7.

Merriman, R.J., Pharaoh, T.C., Woodcock, N.H., Daly, P. 1993. The metamorphic history of the concealed Caledonides of eastern England and their foreland. Geological Magazine 130, 613-620.

Mills, A.J., Dunning, G.R., Langille, A. 2016. New geochronological constraints on the Connecting Point Group, Bonavista Peninsula, Avalon Zone, Newfoundland. In: Current Research. Government of Newfoundland and Labrador, Department of Natural Resources, Geological Survey, Report 16-1, pp 153-171.

Millward, D., 2002. Early Palaeozoic magmatism in the English Lake District. Proceedings of the Yorkshire Geological Society 54, 65-93.

Millward, D. 2006. Caledonian intrusive rocks of northern England and the Midlands. In: Brenchley, P.J., Rawson, P.F. (Eds.). The Geology of England and Wales. The Geological Society, London. 2 nd ed. pp. 147-154.

Millward, D., Moseley, F., Soper, N.J. 1978. The Eycott and Borrowdale Volcanic Rocks. In: Moseley, F. (Ed.). The Geology of the Lake District. Yorkshire Geological Society, Occasional Publication 3, 99-120.

Molyneux, S.G. 1991. The contribution of palaeontological data to an understanding of the Early Palaeozoic framework of eastern England. In: André, L., Herbosch, A., Vanguestaine, M., Verniers, J. (Eds.). Proceedings of the International Meeting on the Caledonides of the Midlands and the Brabant Massif. Annales de la Société Géologique de Belgique 114, 93106.

Molyneux, S.G. 2001. British Geological Survey. Internal Report IR/01/065. 
Mortimer, M.G., Chaloner, W.G. 1972. The palynology of the concealed Devonian rocks of southern England. Bulletin of the Geological Survey of Great Britain 39, 1-56.

Morton, A.C., Waters, C., Fanning, M., Chisholm, J.I, Brettle, M. 2015. Origin of Carboniferous sandstones fringing the northern margin of the Wales-Brabant Massif: insights from detrital zircon ages. Geological Journal 50, 553-574.

Morton, A. C., Whitham, A.G. 2002. The Millstone Grit of northern England: a response to tectonic evolution of a northern sourceland. Proceedings of the Yorkshire Geological Society 54, 47-56.

Moseley, F., Millward, D. 1982. Ordovician volcanicity in the English Lake District. In: Sutherland, D.S. (Ed.) Igneous rocks of the British Isles. pp 19-35. John Wiley and Sons, New York.

Moseley, J.B., Ford, T.D. 1985. A stratigraphic revision of the Late Precambrian rocks of the Charnwood Forest, Leicestershire. Mercian Geologist 10, 1-18.

Murphy, J.B., Fernández-Suárez, H., Jeffries, T.E., Strachan, R.A. 2004. U-Pb (LA-ICP-MS) dating of detrital zircons from Cambrian clastic rocks in Avalonia: erosion of a Neoproterozoic arc along the northern Gondwanan margin. Journal of the Geological Society, London 161, 243-254.

Murphy, J.B., Keppie, J.D., Dostal, J., Nance, R.D. 1999: Neoproterozoic - early Paleozoic evolution of Avalonia. In: Ramos, V.A, Keppie, J.D. (Eds.). Laurentia-Gondwana connections before Pangea. Geological Society ofA merica, Special Papers 336, pp. 253-266.

Murphy, J.B., Strachan, R.A., Nance, R.D., Parker, K.D., Fowler, M.B. 2000. Proto-Avalonia: A 1.2-1.0 Ga tectonothermal event and constraints on the evolution of Rodinia. Geology 28, 1071-1074.

Nance, R.D., Murphy, J.B. 1994. Contrasting basement isotopic signatures and the palinspastic restoration of peripheral orogens: Example from the Neoproterozoic Avalonian-Cadomian belt. Geology 22, 617-620.

Nance, R.D., Murphy, J.B. 1996. Basement isotopic signatures and Neoproterozoic paleogeography of AvalonianCadomian and related terranes in the circum-North Atlantic. In: Nance, R.D., Thompson, M.D (Eds.). Avalonian and Related Peri-Gondwanan Terranes of the Circum-North Atlantic. Geological Society of America, Special Paper 304.

NCS, 2014. (Belgian) National Commission for Stratigraphy, subcommission for lower Palaeozoic. Revised Silurian formations.

Neuman, R.B. 1984. Geology and palaeobiology of islands in the Ordovician Iapetus Ocean: review and implications. Geological Society of America Bulletin 94, 1188-1201.

Newall, A.J. 2017. Rifts, rivers and climate recovery: A new model for the Triassic of England. Proceedings of the Geologists Association http://dx.doi.org/10.1016/j.pgeola. 2017.04.001.

Noble, S.R., Tucker, R.D., Pharaoh, T.C. 1993. Lower Palaeozoic and Precambrian igneous rocks from eastern England, and their bearing on late Ordovician closure of the Tornquist Sea: constraints from U-Pb and Nd isotopes. Geological Magazine $130,738-747$.

Noble, S.R., Condon, D., Carney, J.N., Wilby, P.R., Pharaoh, T.C., Ford, T.D. 2015. Age and global context of the Ediacaran fossils of Charnwood Forest, Leicestershire, UK. Geological Society of America Bulletin http://dx.doi.org/10.11031/B31013.1.

O'Brien, S.J., Dunning, G.R., Knight, I., Dec, T. 1989: Late Precambrian geology of the north shore of Bonavista Bay (Clode Sound to Lockers Bay). In: Report of Activities. Government of Newfoundland Labrador, Department of Mines, Geological Survey, pp 49-50.

O'Brien, B., O'Brien, S., Dunning, G. R. 1991 .Silurian cover, Late Precambrian-Early Ordovician basement, and the chronology of Silurian orogenesis in the Hermitage Flexure (Newfoundland Appalachians). American Journal of Science 291 760-799.

O'Brien, S.J., Wardle, R.J., King, A.F. 1993. The Avalon Zone: A Pan-African terrane in the Appalachian Orogen of Canada. Geological Journal 18, 195-222.

O'Brien, S.J., O'Brien, B.H., Dunning, G.R., Tucker, R.D. 1996: Late Neoproterozoic Avalonian and related periGondwanan rocks of the Newfoundland Appalachians. In: Nance, R.D., Thompson, M.D (Eds.). Avalonian and Related PeriGondwanan Terranes of the Circum-North Atlantic. Geological Society of America, Special Paper 304.

O'Nions, R.K., Oxburgh, E.R., Hawksworth, C.J. et al. 1973. New isotopic and stratigraphic evidence on the age of the Ingletonian - probably Cambrian of northern England. Journal of the Geological Society, London 129, 445-452.

Old, R.A., Hamblin, R.J.O., Ambrose, K., Warrington, G. 1991. Geology of the country around Redditch. Memoir for 1:50 000 geological sheet 183 (England and Wales). HMSO: London.

Paris, F. et al. Chitinozoan-based calibration of Early-Mid Ordovician transgressive events on northern Gondwana. Acta geologica Sinica 46, 370-373. 2007.

Paris, F., Robardet, M. 1990. Early Palaeozoic palaeobiogeography of the Variscan regions. Tectonophysics 177, 193213.

Pauley, J.C. 1990a. The Longmyndian Supergroup and related Precambrian sediments of England and Wales. In: Strachan, R.A., Taylor, G.K. (Eds.) Avalonian and Cadomian geology of the North Atlantic. Blackie, Glasgow and London, pp 5-27.

Peace, G.R., Besly, B.M. 1997. End-Carboniferous fold-thrust structures, Oxfordshire, UK: implications for the structural evolution of the late Variscan foreland of south-central England. Journal of the Geological Society, London 154, 225-237.

Penn, J.S.W., French, J. 1971. The Malvern Hills. Geologists’ Association Guide, No.4.

Pharaoh, T.C. 1999. Palaeozoic terranes and their lithospheric boundaries within the Trans-European Suture Zone (TESZ): a review. Tectonophysics 314, 17-41.

Pharaoh, T.C. 2005. Contributions on Eakring Fault, Glinton Fault and Broadlands Thrust In: Chadwick, R.A., Evans, D.J. (Eds.). Seismic Atlas. Special Publication, British Geological Survey, Nottingham, Nottingham.

Pharaoh, T.C., Brewer, T.S. 1997. Chapter 2. Precambrian. In: Barclay et al. Geology of the country around Worcester. pp. 4-14. Memoir for 1:50 000 sheet 161, British Geological Survey, Nottingham. 
Pharaoh, T.C., Brewer, T.S. 1998. Precambrian geochemistry.In: Bridge et al. Geology of the country around Coventry and Nuneaton. pp13-20. Memoir for 1:50 000 sheet 169, British Geological Survey, Nottingham.

Pharaoh, T.C., Carney, J. 2000. Introduction Chapter 1 In: Carney, J., Horak, J.M., Pharaoh, T.C., Gibbons, W., Wilson, D., Barclay, W.J., Bevins, R.E., Cope, J.C.W., Ford, T.D. Precambrian rocks of England and Wales. pp. 1-18. Geological Conservation Review, Joint Nature Conservation Committee-Chapman \& Hall. 239pp.

Pharaoh, T.C., Evans, C.J. 1987. Morley Quarry No.1 Borehole: Geological Well Completion Report. Investigation of the Geothermal Potential of the UK, British Geological Survey, Nottingham. 43 pp.

Pharaoh, T.C., Gibbons, W.A. 1994. Precambrian rocks in England and Wales south of the Menai Strait Fault System. In: Gibbons, W.A., Harris, A.L. (Eds.), A revised correlation of Precambrian rocks in the British Isles. Geological Society, London, Special Report 22, 85-97.

Pharaoh, T.C., Brewer, T.S., Webb, P.C. 1993a. Subduction-related magmatism of late Ordovician age in eastern England. Geological Magazine 130, 647-656.

Pharaoh, T.C., England, R., Lee, M.K. 1995. The concealed Caledonide basement of Eastern England and the southern North Sea - A review. Chapter 10. In: Gee, D.G., Beckholmen, M. (Eds.), The Trans-European Suture Zone: EUROPROBE in Liblice 1993. Studia Geophysica et Geodaetica 39, 85-97.

Pharaoh, T.C., Merriman, R.J., Webb, P.C., Beckinsale, R.D. 1987a. The concealed Caledonides of eastern England: preliminary results of a multidisciplinary study. Proceedings of the Yorkshire Geological Society 46, 355-369.

Pharaoh, T.C., Webb, P., Thorpe, R.S., Beckinsale, R.D. 1987b. Geochemical evidence for the tectonic setting of late Proterozoic volcanic suites in the central UK. In: Pharaoh, T.C., Beckinsale, R.D., Rickard, D.T. (Eds.), Geochemistry and Mineralisation of Proterozoic Volcanic Suites. Geological Society, London. Special Publications 33, 541-552.

Pharaoh, T.C., Molyneux, S.G., Merriman, R.J., Lee, M.K., Verniers, J. 1993b. The Caledonides of the Anglo-Brabant Massif reviewed. Geological Magazine 130, 561-562.

Pharaoh, T.C., Allsop, J.M., Holliday, D.W., Merriman, R.J., Kimbell, G.S., Rundle, C.C., Brewer, T.S., Noble, S.R., Evans, C.J. 1997. The Moorby Microgranite: a deformed high-level intrusion of Ordovician age in the concealed Caledonian basement of Lincolnshire. Proceedings of the Yorkshire Geological Society 51, 329-342.

Pharaoh, T C, Winchester, J A, Verniers, J, Lassen, A, Seghedi, A. 2006. The western accretionary margin of the east European craton: an overview. In: Gee, D.G., Stephenson, R.A. (Eds). European Lithosphere Dynamics. pp. 291-311. Geological Society, London Memoir 32.

Pharaoh, T.C., Gent, C.M.A., Mellett, C., Greenhalgh, E., Andrews, I.J., McInroy, D.B. 2017. South-West Approaches Study Phase 1 Lot 2: A Review of Late- and Post- Variscan basins and source potential in Western Europe. British Geological Survey Commissioned Report, CR/17/031 130pp.

Pharaoh, T.C., Merriman, R.J., Evans, J.A., Brewer, T.S., Webb, P.C., Smith, N.J.P. 1991. Early Palaeozoic arc-related volcanism in the concealed Caledonides of southern Britain. Annales de la Société Géologique de Belgique 114, 63-91.

Pharaoh, T.C., Vincent, C., Bentham, M., Hulbert, A.G., Waters, C. N., Smith, N. J. P. 2011. Structure and evolution of the East Midlands region of the Pennine Basin. Subsurface memoir of the British Geological Survey, Nottingham. 144pp. ISBN 9780852726716

Pharaoh, T.C., Dusar, M., Geluk, M., Kockel, F., Krawczyk, C., Krzywiec, P., Scheck-Wenderoth, M., Thybo, H., Vejbaek, O., van Wees, J-D. 2010. Chapter 3 Tectonic Evolution In: Doornenbal, J.H., Stevenson, A.G.(Eds.). Petroleum Geological Atlas of the Southern Permian Basin. pp25-58. EAGE, Houten.

Pharaoh, T.C., Gent, C.M.A., Hannis, S.D., Kirk, K.L., Monaghan, A.A., Quinn, M.F., Smith, N.J.P., Vane, C.H., Wakefield, O., Waters, C.N. 2017 (in press). Structure, stratigraphy and hydrocarbon prospectivity of the Carboniferous in the East Irish Sea - North Channel Basin. In: Monaghan, A.A., Underhill, J.R., Marshall, J.E.A. \& Hewett, A. (Eds). Palaeozoic Plays of NW Europe. Special Publication 465, Geological Society of London.

Phillips, E. 1991. The lithostratigraphy, sedimentology and tectonic setting of the Monian Supergroup, western Anglesey, North Wales. Journal of the Geological Society, London 148, 1079-1090.

Pickering, K.T. 1989. The destruction of Iapetus and Tornquist's Oceans. Geology Today 5, 160-166.

Pickering, K.T., Bassett, M.G., Siveter, D.J. 1988. Late Ordovician-early Silurian destruction of the Iapetus Ocean: Newfoundland, British Isles and Scandinavia - a discussion. Transactions of the Royal Society of Edinburgh: Earth Sciences 79, 361-382.

Pidgeon, R.T., Aftalion, M. 1978. Cogenetic and inherited zircon U-Pb systems in Palaeozoic granites from Scotland and England. In: Bowes, D.R, Leake, B.E. Crustal evolution in northwest Britain and adjacent regions, pp 183-220. Geological Journal Special Issue 10. Seal House Press, Liverpool,

Pillola, G.L. 1993. The Lower Cambrian trilobite Bigotina and allied genera. Palaeontology 36, 855-881.

Piper, J.D.A. 1997.Tectonic rotation within the paratectonic British Caledonides and early Palaeozoic location of the orogen. Journal of the Geological Society, London 154, 9-14.

Pollock, J.C., Hibbard, J.P., Sylvester, P.J. 2009: Early Ordovician rifting ofAvalonia and birth of the Rheic Ocean: U$\mathrm{Pb}$ detrital zircon consrtraints from Newfoundland. Journal of the Geological Society, London 166, 501-515.

Prigmore, J.K., Butler, A.J., Woodcock, N.H. 1997. Rifting during separation of Eastern Avalonia from Gondwana: Evidence from subsidence analysis. Geology 25, 203-206.

Pu, J.P., Bowring, S.A., Ramezani, J., Myrow, P., Raub, T.D., Landing, E., Mills, A., Hodgin, E., Macdonald, F.A. 2016: Dodging snowballs: Geochronology of the Gaskiers glaciation and the first appearance of the Ediacaran biota, Geology, Geological Society of America, Data Repository item 2016326; doi:10.1130/G38284.1, 4 pages.

Quirk, D.G., Kimbell, G.S. 1997. Structural evolution of the Isle of Man and central part of the Irish Sea. In: Meadows, N.S., Trueblood, S.P., Hardman, M., Cowan, G. (Eds.). Petroleum Geology of the Irish Sea and Adjacent Areas. Geological Society, London. Special Publication 124, 135-139.

Rast, N., O 'Brien, B.H., Wardle, R.J. 1976. Relationships between Precambrian and Lower Palaeozoic rocks of the Avalon Platform in New Brunswick, the north eastern Appalachians and the British Isles. Tectonophysics 30, 315-338. 
Rastall, R.H. 1907. The Ingletonian series of west Yorkshire. Proceedings of the Yorkshire Geological Society 10, 87100.

Reedman, A.J., Leveridge, B.E., Evans, R.B. 1984.. The Arfon Group ('Arvonian’) of North Wales. Proceedings of the Geologists' Association 95, 313-321.

Reston, T.J. 1990. Mantle shear zones and the evolution of the northern North Sea Basin. Geology 18, 272-275.

Reston, T.J., Blundell, D.J. 1987. Possible mid-crustal shears at the edge of the London Platform. Geophysical Journal of the Royal Astronomical Society 89, 251-258.

Rushton, A.W.A. 1974. The Cambrian of Wales and England. In: Ed. Holland, C.H. (Ed.). The Cambrian of the British Isles, Norden and Spitzbergen (Lower Palaeozoic rocks of the world). pp 3-121. John Wiley and Son, London.

Rushton, A.W.A., Hughes, C.P. 1981. The Ordovician trilobite fauna of the Great Paxton Borehole, Cambridgeshire. Geological Magazine 118, 623-646.

Rushton, A.W.A., Molyneux, S.G. 1990. The Withycombe Formation (Oxfordshire subcrop of early Cambrian age). Geological Magazine 127, 363

Rushton, A.W.A., Brück, P.M., Molyneux, S.G., Williams, M., Woodcock, N.H. 2011. A revised correlation of Cambrian Rocks in the British Isles. Special Report 25, Geological Society, London.

Samson, S.D., D’Lemos, R.S., Miller, B.V., Hamilton, M.A. 2005. Neoproterozoic palaeogeography of the Cadomia and Avalonia terranes: constraints from detrital U-Pb ages. Journal of the Geological Society, London 162, 65-71.

Samuelsson, J., Vecoli, M., Bednarczyk, W.S., Verniers, J. 2002b. Timing of the Avalonia-Baltica plate convergence as inferred from palaeogeographic and stratigraphic data of chitinozoa assemblages in west Pomerania, northern Poland. In: Winchester, J.A., Pharaoh, T.C., Verniers, J. (Eds.). Palaeozoic Amalgamation of Central Europe. Geological Society, London. Special Publications 201, 95-114.

Sandeman, H.A.I., Clark, A.H., Styles, M.T., Scott, D.J., Malpas, J.G., Farrar, E. 1997. Geochemistry and U-Pb and ${ }^{40} \mathrm{Ar}-$ ${ }^{39} \mathrm{Ar}$ geochronology of the Man of War Gneiss, Lizard Complex, SW England: pre-Hercynian arc-type crust with a SudetenIberian connection. Journal of the Geological Society, London 154, 403-447.

Scheck, M., Thybo, H. Lassen, A., Abramovitz, T., Laigle, M. 2002. Basement structures in the southern North Sea, offshore Denmark, based on seismic interpretation. In: Winchester, J.A., Pharaoh, T.C., Verniers, J. (Eds.). Palaeozoic Amalgamation of Central Europe. Geological Society, London. Special Publications 201, 311-326.

Scheck-Wenderoth, M., Krzywiec, P., Zühlke, R., Maystrenko, Y., Froitzheim, N., 2008. Permian to Cretaceous tectonics In:. McCann T. (Ed.) Geology of central Europe. Geological Society, London.

Schofield, D.I., Millar, I.L., Wilby, P., Evans, J.A. 2010. A new, high precision U-Pb date from the oldest known rocks in southern Britain. Geological Magazine 147, 145-150.

Schofield, D.I., Evans, J.A., Millar, I.L., Wilby, P., Aspden, J.A. 2008. New U-Pb and Rb-Sr constraints on pre-Acadian tectonism in North Wales. Journal of the Geological Society, London 165, 891-894.

Schofield, D.I., Potter, J., Barr, S.M., Horak, J.M., Millar, I.L., Longstaffe, F.J. 2016. Reappraising the Neoproterozoic 'East Avalonian' terranes of southern Great Britain. Gondwana Research 35, 257-271.

Scotese, C.R., McKerrow, W.S. 1991. Ordovician plate tectonic reconstructions. In: Barnes, C.R., Williams, S.H. (Eds) Advances in Ordovician Geology Geological Survey of Canada Paper 90-9, 271-282.

Servais, T., Vanguestaine, M., Herbosch, A. 1993. Review of the stratigraphy of the Ordovician in the Brabant Massif, Belgium. Geological Magazine 130, 699-710.

Shackleton, R.M. 1969. The Pre-Cambrian of North Wales. In: Wood, A. (Ed.). The Pre-Cambrian and Lower Palaeozoic rocks of Wales. pp 1-22. University of Wales Press, Cardiff.

Shackleton, R.M. 1975. Precambrian rocks of North Wales, In: Harris, A.L. et al. A correlation of the Precambrian rocks in the British Isles. Special Report of the Geological Society, London 6, pp 76-82.

Shail, R.K., Leveridge, B.E. 2009.The Rhenohercynian passive margin of S W England: development, inversion and extensional reactivation. Comptes Rendus Geoscience 341, 140-155.

Sherlock, S.C., Kelley, S.P., Zalasiewicz, J., Schofield, D., Evans, J., Merriman, R.J., Kemp, S.J. 2003. Precise dating of low-temperature deformation: strain-fringe analysis by ${ }^{40} \mathrm{Ar}-{ }^{39} \mathrm{Ar}$ laser microprobe. Geology 31, 219-222.

Sintubin, M. 1999. Arcuate fold and cleavage patterns in the southeastern part of the Anglo-Brabant Fold Belt (Belgium): tectonic implications. In: Sintubin, M., Vandycke, S., Camelbeeck, T. (Eds.) Palaeozoic to Recent tectonics in the NW European Variscan Front Zone. Tectonophysics 309, 81-97.

Sintubin, M., Everaerts, M.A. 2002. A compressional wedge model for the Lower Palaeozoic Anglo-Brabant Belt (Belgium). based on the potential field data. In: Winchester, J. A., Pharaoh, T. C., Verniers, J. (Eds.) Palaeozoic Amalgamation of Central Europe. Geological Society, London. Special Publications 201, 327-344.

Smith, B., George, T.N. 1935. British Regional Geology North Wales. Geological Survey of Great Britain.

Smith, D.B., Taylor, J.C.M. Permian. In: Cope, J.C.W., Ingham, J.K., Rawson, P.F. (Eds.). Atlas of Palaeogeography and Lithofacies. pp. 87-96. Geological Society, London.

Smith, N.J.P. (Compiler) 1985. Pre-Permian geology of the United Kingdom (South). British Geological Survey, Nottingham.

Smith, N.J.P. 1987. The deep geology of central England: the prospectivity of the Palaeozoic rocks. In: Brooks, J., Glennie, K. (Eds.). Petroleum Geology of Northwest Europe, pp. 217-224. Graham \& Trotman, London.

Smith, N.J.P. 1993. The case for exploration of deep plays in the Variscan fold belt and its foreland. In: Parker, J. (Ed.). Petroleum Geology of Northwest Europe: Proceedings of the $4^{\text {th }}$ Conference. , London.

Smith, N.J.P., Rushton, A.W.A., 1993. Cambrian and Ordovician stratigraphy related to structure and seismic profiles in the western part of the English Midlands. Geological Magazine 130, 665-671.

Smith, N.J.P., Thomas, C.W. 2015. Chapter 2. Concealed geology. In: Lee, J.R., Woods, M.A., Moorlock, B.S.P. (Eds). British Regional Geology: East Anglia (Fifth edition). British Geological Survey, Nottingham. 
Smith, N.J.P, Kirby, G.A., Pharaoh, T.C. 2005. The structure and evolution of the south-west Pennine. Basin. Subsurface Memoir, British Geological Survey, Nottingham.

Soper, N., Hutton, D. H. W. 1984. Late Caledonian sinistral displacements in Britain: Implications for a three-plate collision model. Tectonics 3, 781-794.

Soper, N.J., Dunning, F.W., 2005. Structure and sequence of the Ingleton Group, basement to the central Pennines of northern England. Proceedings of the Yorkshire Geological Society 55, 241-261.

Soper, N.J., Woodcock, N.H., 1990. Silurian collision and sediment dispersal patterns in southern Britain. Geological Magazine 127, 527-542.

Soper, N.J., Woodcock, N.H., 2003. The lost Lower Old Red Sandstone of England and Wales: a record of post-Iapetan flexure or Early Devonian transtension? Geological Magazine 140, 627-647.

Soper, N.J., Webb, B.C., Woodcock, N.H., 1987. Late Caledonian (Acadian) transpression in North West England: timings, geometry and geotectonic significance. Proceedings of the Yorkshire Geological Society 46, 175-192.

Strachan, R.A., 2012. Chapter 8. Late Neoproterozoic to Cambrian Accretionary History of Eastern Avalonia and Armorica on the Active Margin of Gondwana. In: Woodcock, N.H., Strachan, R.A. (Eds.). Geological History of Britain and Ireland. Blackwell Publishing Ltd, Oxford. 2nd ed. 442pp.

Strachan, R.A., Nance, R.D., Dallmeyer, R.D., D’Lemos, R.S., Murphy, J.B., Watt, G.R. 1996. Late Precambrian tectonothermal evolution of the Malverns Complex. Journal of the Geological Society, London 153, 589-600.

Strachan, R.A., Collins, A.S., Buchan, C., Nance, R.D., Murphy, J.B., D’Lemos, R.S. 2007. Terrane analysis along a Neoproterozoic active margin of Gondwana: insights from U-Pb zircon geochronology. Journal of the Geological Society, London 164, 57-60.

Stubblefield, C J. 1967. Some results of a recent Geological Survey boring in Huntingdonshire. Proceedings of the Geological Society, London. 1637, 35-38.

Tanner, B., Meissner, R. 1996. Caledonian deformation upon southwest Baltica and its tectonic implications: Alternatives and consequences. Tectonics 15, 803-812.

Thompson, M.D., Ramezani, J., Crowley, J.L. 2014: U-Pb zircon geochronology of Roxbury Conglomerate, Boston Basin, Massachusetts: Tectonostratigraphic implications for Avalonia in and beyond SE New England. American Journal of Science 314, 1009-1040.

Thorogood, E.J. 1990. Provenance of the Pre-Devonian sediments of England and Wales. Journal of the Geological Society, London 147, 591-94.

Thorpe, R.S., Gaskarth, J.W., Henney, P. 1993. Tectonic setting of Caledonian minor intrusions of the English Midlands. Geological Magazine 130, 657-663.

Thorpe, R.S. 1972. The geochemistry and correlation of the Warren House, the Uriconian and the Charnian volcanic rocks from the English Precambrian. Proceedings of the Geologists' Association 83, 269-285.

Thorpe, R.S. 1974. Aspects of magmatism and plate tectonics in the Precambrian of England and Wales. Geological Journal 9, 115-135.

Thorpe, R.S., Leat, P.T., Bevins, R.E., Hughes, D.J. 1989. Late orogenic alkaline/subalkaline Silurian volcanism of the Skomer Volcanic Group in the Caledonides of South Wales. Journal of the Geological Society, London 146, 125-132.

Thorpe, R.S., Beckinsale, R. D., Patchett, P.J., Piper, A., Davies, G.R., Evans, J.A. 1984. Crustal growth and late Precambrian-early Palaeozoic plate tectonic evolution of England and Wales. Journal of the Geological Society, London 141, 521-536.

Tietzsch-Tyler, D., Phillips, E.R. 1989. Correlation of the Monian Supergroup in NW Anglesey with the Cahore Group in SE Ireland. Journal of the Geological Society, London 141, 417-418.

Toghill, P. 1992. The Shelveian event, a late Ordovician tectonic episode in Southern Britain (Eastern Avalonia). Proceedings of the Geologists Association 103, 31-35.

Toghill, P., Schell, K. 1984. Shropshire geology - stratigraphic and tectonic history. Field Studies 6, 59-101.

Tomlinson, J.P., Denton, P., Maguire, P.K.H., Booth, D.C., 2006. Analysis of the crustal velocity structure of the British Isles using teleseismic receiver functions. Geophysical Journal International 167, 223-237.

Torsvik, T.H., Cocks, L.R.M. 2017. Earth History and Palaeogeography. Cambridge University Press, Cambridge. 317pp.

Torsvik T.H., Rehnstrőm, E.F. 2001. Cambrian palaeomagnetic data from Baltica: implications for true polar wander and Cambrian palaeogeography. Journal of the Geological Society, London 158, 321-329.

Torsvik T.H., Rehnström, E.F. 2003. The Tornquist Sea and Baltica-Avalonia docking. Tectonophysics 362, 67-82

Torsvik, T.H., Trench, A. 1991. The Ordovician history of the Iapetus Ocean in Britain: new palaeomagnetic constraints. Journal of the Geological Society, London 148, 423-425.

Torsvik, T.H., Smethurst, M.A., Van Der Voo, R., Trench, A., Abrahamsen, N., Halvorsen, E., 1992. Baltica. A synopsis of Vendian-Permian palaeomagnetic data and their palaeotectonic interpretation. Earth Science Reviews 33, 133-152.

Trela, W., Bak, E., Pańczyk, M, 2017. Upper Ordovician and Silurian ash beds in the Holy Cross Mountains, Poland: preservation in mudrock facies and relation to atmospheric circulation in the Southern Hemisphere. Journal of the Geological Society, London 174.

Trench, A., Torsvik, T.H. 1992. The closure of the Iapetus Ocean and Tornquist Sea: new palaeomagnetic constraints. Journal of the Geological Society, London 149, 867-870.

Trueman, A.E., 1946. Coal Measure Stratigraphy. Presidential Address to the Geological Socirty of London. Quarterly Journal of the Geological Society, London 102.

Trueman, A.E., 1947. Coal Measure Stratigraphy. Presidential Address to the Geological Socirty of London. Quarterly Journal of the Geological Society, London 103.

Tucker, R.D., McKerrow, W.S. 1995. Early Palaeozoic chronology: a review in light of new U-Pb zircon ages from Newfoundland and Britain. Canadian Journal of Earth Sciences 32, 363-379. 
Tucker, R.D., Pharaoh, T.C. 1991. U-Pb zircon ages for Late Precambrian igneous rocks in southern Britain. Journal of the Geological Society, London 148, 435-443.

Tucker, R.D., Robinson, P.D. 1990. Age and setting of the Bronson Hill magmatic arc: A re-evaluation based on U-Pb zircon ages in southern New England. Geological Society of America Bulletin 102, 1404-1419.

Tucker, R. D., Osberg, P. H., Berry IV, H. N. 2001 .The geology of a part of Acadia and the nature of the Acadian orogeny across central and eastern Maine. American Journal of Science 301, 205-260.

Tunbridge, I. P. 1981. Sandy high-energy flood sedimentation - some criteria for recognition, with an example from the Devonian of S.W. England. Sedimentary Geology 28, 79-95.

Turner, J.S. 1935. Gothlandian vulcanicity in Western Europe. Geological Magazine 72, 145-151.

Turner, J.S. 1949. The deeper structure of central and northern England. Proceedings of the Yorkshire Geological Society 27, 280-297.

Unrug, R., Harańczyk, C., Chocyk-Jamińska, M. 1999. Easternmost Avalonia and Armorican-Cadomian terranes of central Europe and Caledonian-Variscan evolution of the polydeformed Kraków mobile belt: geological constraints. Tectonophysics 302, 133-157.

Valverde-Vaquero, P., van Staal, C. R, McNicoll, V., Dunning, G. 2006. Middle Ordovician magmatism and metamorphism along the Gander margin in Central Newfoundland. Journal of the Geological Society, London 163, 347-362.

Van Der Kamp, P.C. 1969. Silurian volcanic rocks of the Mendip Hills, Somerset and Tortworth, Gloucestershire, England. Geological Magazine 106, 542-555.

Van Grootel, G., Verniers, J., Geerkens, B., Laduron, D., Verhaeren, M., Hertogen, J., De Vos, W. 1997. Timing of magmatism, foreland basin development, metamorphism and inversion in the Anglo-Brabant fold belt. Geological Magazine 134, 607-616.

Van Staal, C. 1994. The Brunswick subduction complex in the Canadian Appalachians: Record of the Late Ordovician to Late Silurian collision between Laurentia and the Gander margin of Avalon. Tectonics 13, 946-962.

Van Staal, C.R., Fyffe, L.R., 1995. The New Brunswick Gander Zone. In: H. Williams (co-ordinator).The Appalachian/ Caledonian Orogen: Canada and Greenland. Decade of North American Geology, Volume F-1, 216-223

Van Staal, C.R., de Roo, J. A. 1995. Mid-Paleozoic tectonic evolution of the Appalachian Central Mobile Belt in northern New Brunswick, Canada: Collision, extensional collapse, and dextral transpression. In: Hibbard, J. Van Staal, C. R., Cawood, P. (Eds.) Current Perspectives in the AppalachianCaledonian Orogen., pp. 367-389.Geological Association of Canada, Special Paper 41

Van Staal, C.R., Barr, S., 2012. Lithospheric Architecture and Tectonic Evolution of the Canadian Appalachians and Associated Atlantic Margin. In: .Clowes, R; Percival, J. and Cook, E, (Eds.). Tectonic styles in Canada: the LITHOPROBE Perspective, pp. 41-95. Geological Association of Canada Special Paper 49

Van Staal, C.R., Zagorevski, 2017.Van Staal, C. R., Sullivan, R. W., Whalen, J. B. 1996. Provenance and tectonic history of the Gander Margin in the Caledonian/Appalachian Orogen: Implications for the origin and assembly of Avalonia. In: Nance, R. D., Thompson, M. D. (Eds.) Avalonian and Related Pen-Gondwanan Terranes of the Circum-North Atlantic, 347367.Geological Society of America, Special Paper 304.

Van Staal, C.R., Dewey, J. F., MacNiocaill, C., McKerrow, S. 1998. The Cambrian-Silurian tectonic evolution of the northern Appalachians: History of a complex, southwest Pacific-type segment of lapetus. In: Blundell, D. J., Scott, A.C. (Eds.) Lyell: the Past is the Key to the Present. Geological Society, London, pp. 199-242. Special Publication 143.

Van Staal, C.R., Wilson, R. A, Rogers, N., Fyffe, L. R., Langton, J. P., McCutcheon, S. R., McNicoll, V., Ravenhurst, C. E. 2003. Geology and tectonic history of the Bathurst Supergroup and its relationships to coeval rocks in southwestern New Brunswick and adjacent Maine - a synthesis. In::Goodfellow, W.D., McCutcheon, S.R.,Peter, J.M. (Eds.) Massive Sulfide Deposits of the Bathurst Mining Camp, New Brunswick, and Northern Maine. pp. 37-60, Economic Geology, Monograph 11..

Van Staal, C. R., Whalen, J. B., Valverde-Vaquero, P., Zagorevski,A., Rogers, N. 2009. PreCarboniferous, episodic accretion-related, orogenesis along the Laurentian margin of the northern Appalachians. In: J. B. Murphy J. D. Keppie, A. J.Hynes (Eds.). Ancient orogens and modern analogues. Geological Society, London. Special Publication 327, 271-316

Van Staal, C. R, Barr, S., Fyffe, L. R., Johnson, S. C., Park, A. F., White, C. E., Wilson, R. E, 2011. The defining tectonic elements of Ganderia in New Brunswick; Geological Association of Canada -Mineralogical Association of Canada -Society of Economic Geologist- Society for Geology Applied to Mineral Deposits Joint Annual Meeting, Ottawa 2011, Guidebook to Field Trip 1B, 12-17.

Van Staal, C. R., Barr, S. M., Murphy, J. B., 2012. Provenance and tectonic evolution of Ganderia: constraints on the evolution of the lapetus and Rheic oceans. Geology 40, 987-990.

Vanguestaine, M. 1992. Biostratigraphie par acritarches du Cambro-Ordovicien de Belgique et des regions limitrophes: synthèse et perspectives d'avenir. Annales de la Société Géologique de Belgique 115, 1-18.

Verniers, J., Van Grootel, G. 1991. Review of the Silurian in the Brabant Massif, Belgium. In: André, L., Herbosch, A., Vanguestaine, M., Verniers, J. (Eds.). Proceedings of the International Meeting on the Caledonides of the Midlands and the Brabant Massif. André, L., Herbosch, A., Vanguestaine, M., Verniers, J. (Eds.). Annales de la Société Géologique de Belgique 114, 163-194

Verniers, J., Herbosch, A., Vanguestaine, M. Geukens, E, Delcambre, B, Pingot, J. L., Belanger, L, Hennebert, M., Debacker, T., Sintubin, M., De Vos, W. 2001. Cambrian-Ordovician-Silurian lithostratigraphical units (Belgium). In: Bultynck, P., Dejonghe, L. (Eds.) Guide to a revised lithostratigraphic scale of Belgium. Geological Belgica 4, 5-38.

Verniers, J., Van Grootel, G., Debacker, T.N. 2005. The Upper Ordovician lithostratigraphy and structure of the Fauquez area (Brabant Massif, Belgium). Geologica Begica 8, 160-175.

Verniers, J., Pharaoh, T.C., André, L., Debacker, T., De Vos, W., Everaerts, M., Herbosch, A., Samuelsson, J., Sintubin, M., Vecoli, M. 2002. The Cambrian to mid Devonian basin development and deformation history of Eastern Avalonia, east of the Midlands Microcraton: new data and a review. In: Winchester, J.A., Pharaoh, T.C., Verniers, J. (Eds.). Palaeozoic Amalgamation of Central Europe. Geological Society, London. Special Publication 201, 47-94. 
Vizan, H., Carney, J.N., Turner, P., Ixer, R.A., Tomasso, M., Mullen, R.P., Clarke, P. 2003. Late Neoproterozoic palaeogeography of Avalonia: some palaeomagnetic constraints from Nuneaton, central England. Geological Magazine 140, 685-705.

Waldron, J.W.F., Schofield, D.I., White, C.E., Barr, S.M. 2011. Cambrian successions of the Meguma Terrane, Nova Scotia, Canada, and Harlech Dome, North Wales, UK: dispersed fragments of a peri-Gondwanan basin? .Journal of the Geological Society, London 168, 83-98.

Walkden, G. M., Davies, J. 1983. Polyphase erosion of subaerial omission surfaces in the late Dinantian of Anglesey, North Wales. Sedimentology 30, 861-878.

Warrington, G., Ivimey-Cook, H.C. 1992. Triassic. In: Cope, J.C.W., Ingham, J.K., Rawson,P.F. (Eds.). Atlas of Palaeogeography and Lithofacies. Geological Society, London. pp97-106. Memoir 13

Waters, C.N., Chisholm, J.I., Benfield, A.C., O'Beirne, A.M. , 2008. Regional evolution of a fluviodeltaic cycle succession in the Marsdenian (late Namurian Stage, Pennsylvanian) of the Central Pennine Basin, UK.. Proceedings of the Yorkshire Geological Society 57, 1-28.

Waters, C.N., Somerville, I. et al., 2011. A Revised Correlation of Carboniferous Rocks in the British Isles. Geological Society, London. Special Report No. 26.

Webb, B.C., Cooper, A.H. 1988. Slump folds and gravity slide structures in a Lower Palaeozoic marginal basin sequence (the Skiddaw Group), N W England. Journal of Structural Geology 10. 463-472.

White, R.S., Smith, L.K., et al. 2008. Lower-crustal intrusion on the North Atlantic continental margin. Nature 452, 460-464.

Whittaker, A. 1985.(Ed.).Atlas of onshore sedimentary basins in England and Wales. Post-Carboniferous tectonics and stratigraphy. Blackie, Glasgow and London.

Wilby, P. 2017. (this volume).

Williamson, J. P., Pharaoh, T. C., Banka, D., Thybo, H., Laigle, M., Lee, M. K. 2002. Potential field modelling of the Baltica-Avalonia (Thor-Tornquist) suture beneath the southern North Sea. Tectonophysics 360, 47-60.

Williams, H. 1979. Appalachian Orogen in Canada. Canadian Journal of Earth Sciences 16, 792-807.

Williams, H., Lafrance, B., Dean, P. L., Williams, P. F., Pickering, K. T., van der Pluijm, B. A.1995. Badger Belt. In: Williams, H. (Ed.) The Appalachian/Caledonian Orogen: Canada andGreenland. Geological Survey of Canada, Geology of Canada 6, 403-413 (also Geological Society of America, the Geology of North America, F-1 ).

Williams, H., Hatcher, R.D. Jr. 1982. Suspect terranes and the accretionary history of the Appalachian orogen. Geology $16,530-536$

Willner, A.P., Barr, S.M., Gerdes, A., Massonne, H.-J., White, C.E. 2013..Origin and evolution of Avalonia: evidence from $\mathrm{U}-\mathrm{Pb}$ and $\mathrm{Lu}-\mathrm{Hf}$ isotopes in zircon from the Mira Terrane, Canada, and the Stavelot-Venn Massif, Belgium. Journal of the Geological Society, London 170, 769-784.

Wills, L.J. 1948. The Palaeogeography of the Midlands. 144pp. Hodder and Stoughton: London. .

Wills, L.J. 1951. Palaeogeographical Atlas. 64pp. Blackie, Glasgow and London.

Wills, L. J. 1956. Concealed coalfields. Blackie, Glasgow and London

Wills, L J. 1973. Palaeogeological map of the Palaeozoic floor below Permian and Mesozoic formations in England and Wales. Geological Society, London. Memoir No. 7.

Wills, L.J. 1978. A Palaeogeological map of the Lower Palaeozoic Floor, below the cover of Upper Devonian, Carboniferous and later formations. Geological Society, London. 36pp. Memoir 8.

Wilson, J.T. 1966. Did the Atlantic close and then reopen? Nature 211, 676-681.

Winchester, J. A. 2002. Palaeozoic amalgamation of Central Europe: new results from recent geological and geophysical investigations. Tectonophysics 360, 5-21.

Winchester, J. A., Van Staal, C.R. 1994. The chemistry and tectonic setting of Ordovician volcanic rocks in northern Maine and their relationship with contemporary volcanic rocks in northern New Brunswick. American Journal of Science 294 , 641-662.

Winchester, J.A., Pharaoh, T.C., Verniers, J. 2002. Palaeozoic amalgamation of Central Europe: an introduction and synthesis of new results from recent geological and geophysical investigations. In: Winchester, J.A., Pharaoh, T.C., Verniers, J. (Eds.). Palaeozoic Amalgamation of Central Europe. Geological Society, London. Special Publications 201, 1-18.

Wilson, A.A., Cornwell, J.D. 1982. The Institute of Geological Sciences borehole at Beckermonds Scar, North Yorkshire. Proceedings of the Yorkshire Geological Society 44, 59-88.

Woodcock, N.H. 1984a. Early Palaeozoic sedimentation and tectonics in Wales. Proceedings of the Geologists' Association of London 95, 323-335.

Woodcock, N.H. 1984b. The Pontesford Lineament, Welsh Borderland. Journal of the Geological Society, London 141, 1001-1014

Woodcock, N.H. 1988. Strike-slip faulting along the Church Stretton Lineament, Old Radnor, Welsh Borderland. Journal of the Geological Society, London 145, 925-933. 547

Woodcock, N.H. 1990. Sequence stratigraphy of the Welsh Basin. Journal of the Geological Society, London 147, 537-

Woodcock, N.H. 1991. The Welsh, Anglian and Belgian Caledonides compared. In: André, L., Herbosch, A., Vanguestaine, M., Verniers, J. (Eds.). Proceedings of the International Meeting on the Caledonides of the Midlands and the Brabant Massif. Annales de la Société Géologique de Belgique, 114, 5-18.

Woodcock, N.H. 2012a. Chapter 9. The Cambrian and Earliest Ordovician Quiescent Margin of Gondwana. p150-161. In: Woodcock, N.H., Strachan, R.A. 2012. (Eds.). Geological History of Britain and Ireland. 442pp. Blackwell Publishing Ltd, Oxford. 2nd ed.

Woodcock, N.H. 2012b. Chapter 10. Ordovician Volcanism and Sedimentation on Eastern Avalonia.In: Woodcock, N.H., Strachan, R.A. 2012. (Eds.). Geological History of Britain and Ireland. 442pp. Blackwell Publishing Ltd., Oxford. 2nd ed. 
Woodcock, N.H. 2012c. Chapter 11. Late Ordovician to Silurian Evolution of Eastern Avalonia during Iapetus Closure. In: Woodcock, N.H., Strachan, R.A. 2012. (Eds.). Geological History of Britain and Ireland. 442pp.Blackwell Publishing Ltd., Oxford. 2nd ed.

Woodcock, N.H. 2012d. Chapter 12. Early Devonian Sedimentary and Magmatic Interlude after Iapetus Closure. In: Woodcock, N.H., Strachan, R.A. 2012. (Eds.). Geological History of Britain and Ireland. 442pp.Blackwell Publishing Ltd., Oxford. 2nd ed.

Woodcock, N.H. 2012e. Chapter 13. The Acadian Orogeny and its Mid-Late Devonian Depositional Aftermath. In: Woodcock, N.H., Strachan, R.A. 2012. (Eds.). Geological History of Britain and Ireland. 442pp.Blackwell Publishing Ltd., Oxford. 2nd ed.

Woodcock, N.H., Gibbons, W. 1988. Is the Welsh Borderland Fault System a terrane boundary? Journal of the Geological Society, London 145, 915-933.

Woodcock, N.H., Pauley, J.C. 1989. The Longmyndian rocks of the Old Radnor Inlier, Welsh Borderland. Geological Journal, 24, 113-120.

Woodcock, N.H., Pharaoh, T.C. 1993. Silurian facies beneath East Anglia. Geological Magazine 130, 681-690.

Woodcock, N.H., Soper, N.J. 2006. The Acadian Orogeny: the mid-Devonian phase that formed the slate belts in England and Wales. In: Brenchley, P.J., Rawson, P.F. (Eds.). The Geology of England and Wales. Geological Society, London. 131146.

Woodcock, N.H., Strachan, R.A. 2012. (Eds.). Geological History of Britain and Ireland. 442pp.Blackwell Publishing Ltd., Oxford. 2nd ed.

Woodcock, N.H., Soper, N.J., Strachan, R.A. 2007. A Rheic cause for the Acadian deformation in Europe. Journal of the Geological Society, London 164, 1023-1036.

Worssam, B.C., Old, R.A. 1988. Geology of the country around Coalville. Memoir for 1:50 000 geological sheet 155 (England and Wales). HMSO: London.

Wright, A. E., Fairchild, I. J., Moseley, F., Downie, C. 1993. The Lower Cambrian Wrekin Quartzite and the age of its unconformity on the Ercall Granophyre. Geological Magazine, 130, 257-264.

Zhu, H., Bozdag, E., Peter, D, Tromp, J. 2012. Seismic wave speed images across the Iapetus and Tornquist suture zones. Geophysical Research Letters 39.

Zhu, H., Bozdag, E., Tromp, J. 2015. Seismic structure of the European upper mantle based on adjoint tomography. Geophysical Journal International 201, 18-52.

Ziegler, P.A. 1982. Geological Atlas of Western and Central Europe. pp. 130 and 40 plates.Shell International Petroleum Maatschappij BV. The Hague.

Ziegler, P.A. 1990. Geological Atlas of Western and Central Europe,. pp 239 and 56 plates.Shell Internationale Petroleum Maatschappij B.V.-2nd Edition. Geological Society, London and Elsevier, Amsterdam

Ziegler, P.A., Dèzes, P. Crustal Evolution of Western and Central Europe. Gee, D.G, Stephenson, R.A. (Eds). European Lithosphere Dynamics. Geological Society, London pp, 43-56.Memoir 32.

Zielhuis, A., Nolet, G. 1994. Deep Seismic Expression of an Ancient Plate Boundary in Europe. Science, 265, 79-81.

Figure List

Fig. 1. The location of the Anglo-Brabant Massif, as defined by extensional fault systems of Carboniferous (blue), Permo-Triassic (red) and Mesozoic age (green) (after BGS, 1996). The location of the cross-sections Figs. $4 \mathrm{a}$ and $4 \mathrm{~b}$ is shown. Caledonian terrane boundaries south of the Iapetus Suture are slightly modified after Bluck (1992) and BGS (1996). Boundary between Lakesman-Leinster Terrane and Wexford-Môn-Ingletonian Terrane ('Irish Sea Horst', and probable Ganderian correlative) following Soper and Dunning (2008). Key to faults and lineaments: AL, Askrigg Line; BAF, Bala Fault; BEF, Bryneglwys Fault; CHT, Carmel Head Thrust; CPFS, Causey Pike Fault System, CSF, Church Stretton Fault Zone; DL, Dent Line; D-SHL, Dowsing-South Hewett Lineament; EGL, Eakring-Glinton Lineament; EVF, Enville Fault; FHFZ, Vale of Pickering-Flamborough Head Fault Zone; GFM, Grande Faille du Midi, HSZ, Hollywood Shear Zone; IS, Iapetus Suture Zone; ISLS, Irish Sea Lineament (South); LEF, Lask Edge Fault; LLF, Lowther Lodge Fault; LSZ, Lŷn Shear Zone; MCEM?, Conjectured Microcraton Eastern Margin; MCFZ, Morley-Campsall Fault Zone; MCWM, Microcraton NW Margin; MDFB, Môn-Deemster Fold-Thrust Belt; ML, Malvern Line; MSFS, Menai Strait Fault System; N-AFZ, Nieuwpoort-Asquempont Fault Zone; NT, Niarbyl Thrust; P-S-W-BL, Perrenporth-Start-Wight-Bray Line; PA, Pennine Axis; PL, Pendle Lineament; PLL, Pontesford-Linley Fault; RFB, Ribblesdale Foldbelt, N margin; RRF, Red Rock Fault; SBL, Southern Borrowdale Lineament; SCF, South Craven Fault; ST, Skiddaw Thrust; SZ-NADB, Saxothuringian-North Armorican Domain boundary; TF, Thringstone Fault; UF, Unnamed Fault; VF, Variscan Front; WF, Wem Fault; WBFS, Welsh Borderland Fault System; WFZ, Wicklow Fault Zone.

Fig. 2. Nomenclature: the changing faces of the Anglo-Brabant Massif, and the age limits of the incorporated terranes. 
Fig. 3. Crustal structure of the ABM, whose outline is indicated. a. Moho depth (in km), b. Top Basement depth (in km), c. Thickness of crystalline crust (in km). After Chadwick et al. (1996) and Chadwick and Pharaoh (1998).

Fig. 4. Crustal cross-sections across the Welsh and Anglo-Brabant massifs. Locations are shown on Fig. 1.

a. Schematic N-S cross-section of interpreted crustal and upper mantle structure beneath LISPB-Delta seismic refraction profile largely across the Welsh Massif (reproduced, with permission, from Maguire et al., 2011). Key: BF, Bala Fault; BCFZ, Bristol Channel Fault Zone; CSF, Church Stretton Fault; SVD, Swansea Valley Disturbance; VF, Variscan Front. Labels indicate possible lithological interpretation of the seismic model layering. 'Old Red Sandstone +' is poorly defined. In addition to Devonian (ORS) lithologies, it also includes Triassic and Carboniferous either side of the Bristol Channel, as well as Silurian locally.

b. Schematic SW-NE cross-section in eastern part of ABM, after Smith and Thomas (2015). Key:

1. Seismically imaged deep reflector extending into the mantle and interpreted as a former (late Ordovician) subduction zone, now the suture between the Avalonia Terrane and the Southern North Sea Terrane.

2. Deformed early Palaeozoic sedimentary and volcanic rocks with late Ordovician calc-alkaline plutons resulting from subduction of part of the Tornquist Sea beneath the Avalonia Terrane.

3. Unknown, but possibly metamorphosed volcanic and plutonic rocks of Neoproterozoic age.

4. Acadian (early-mid Devonian) unconformity developed on the eroded Anglo-Brabant Deformation Belt.

5. Seismically imaged stack of mid-crustal reflectors, possibly the eastern imbricated edge of the Avalonia Terrane.

6. Glinton Thrust, possibly developed as a back-thrust above the late Ordovician subduction zone and reactivated during late Caledonian deformation.

7. Late Palaeozoic and Mesozoic fill of the Southern North Sea basin.

8. Deformed and metamorphosed rocks of the Anglo-Brabant Deformation Belt.

Fig. 5. A. Magnetic and B. Gravity potential fields. Bouguer anomaly onshore combined with free air anomaly offshore. Anomaly colour scales range from positive (red) to negative (blue). For key to major faults and lineaments see Fig. 1. Key to magnetic anomalies described in the text: BMA, Birmingham Magnetic Anomaly; DSIMA, Derby-St Ives Magnetic Anomaly; FINMA, FurnessIngleton-Norfolk Magnetic Anomaly (after Wills, 1978; Allsop et al., 1987; Cornwell and Walker, 1989; Pharaoh et al., 1993a); CEMA (South Central England Magnetic Anomaly (after Lee et al., 1990; Busby et al., 1993); CCMA, Central Channel Magnetic anomalies; HMA, Harlech Magnetic Anomaly; MMA, Malvern Magnetic Anomaly; WBMA, Welsh Borderland Magnetic Anomaly.

Fig. 6. Shear wave velocity anomalies from tomographic inversion of seismograph records: horizontal slices through the $\mathrm{EU}_{60}$ model of Zhu et al. (2015). The assistance of Geoff Kimbell in extracting the depth slices is gratefully acknowledged.

Fig. 7. Tectonic boundaries of Neoproterozoic crust within the Avalon and Monian composite terranes (after Pharaoh and Carney, 2000). For key to major faults and lineaments see Fig. 1. Key: solid red ornament, outcrop; dots, borehole provings: BaH, Bardon Hill; BrT, Bryn Teg; Col, Collington 1; Edg, Edgmond 1; Fow, Fownhope 1; Gli, Glinton 1; HeF, Heath Farm 1; Kem, Kempsey 1; MoQ, Morley Quarry; Ort, Orton; OxH, Oxendon Hall; StB, Stretton Baskerville; WiF, Withycombe Farm; Wrb,Wrekin Buildings (Telford 2).

Fig. 8. Palaeogeographic location of the ABM and Avalonia Terrane (AV) through Palaeozoic time (after C. Scotese, as presented in Pharaoh et al. 2011). Location of the ABM shown with large red dot.

Fig. 9. Synoptic stratigraphic chart for early Palaeozoic basement of the British, Irish and Belgian Caledonides south of the Iapetus Suture. System and stage names and ages from Gradstein et al. (2012). 
Compiled from the following literature sources: Cambrian, Rushton et al. (2011), Herbosch and Verniers (2013). Ordovician, Fortey et al. (2000), Herbosch and Verniers (2014). Silurian, Cocks et al. (1992). General, Woodcock (1991), Woodcock (2012a, b, c, d). Key to borehole codes: see key to Figs. 10, 13 and 15. Key to abbreviations: DL, Dent Line; FM, Formation; GP, Group; IS, Iapetus Suture; ML, Malvern Line; MSFS, Menai Strait Fault System; PEM, Platform Eastern Margin; SGP, Supergroup; VF, Variscan Front; WBFS, Welsh Borderland Fault System. Key U-Pb ages (black dots with analytical errors) after Noble et al. (1993); Pharaoh et al. (1997) and Linnemann et al. (2012). Note the relatively large errors for the Anglian samples compared to Belgium. N.B. two facing page spread

Fig. 10. Cambrian-Tremadocian outcrop and borehole provings in southern Britain. Base map for UK modified from UCAL (Acadian Unconformity) Map by Nigel Smith (unpublished) and for Belgium, after De Vos et al. (1993). For key to major faults and lineaments see Fig. 1. Outcrop, solid ornament. Key to borehole provings. Early-middle Cambrian in black: Fob, Fobbing; SaF, Sapcote Freeholt (Elmesthorpe); Fow, Fownhope 1; Kin, Kineton; Me3, Merevale No. 3; MoF, Moor Farm; Rot, Rotherwood; Tic, Ticknall (Calke Abbey); WiF, Withycombe Farm. Possible Cambrian provings: Bay, Bardney 1; GH2, Ellington; Fos, Foston 1; GaH, Galley Hill; Gro, Grove 3; Hus, Hunstanton 1; Gh10, Huntingdon 10; GH5, Huntingdon 5; Lex, Lexham 1; Noc, Nocton 1; Sib, Sibsey 1; SCr, South Creake 1; Spa, Spalding 1; Stx, Stixwould 1; Wel, Welton 1; Wes, Wessenden 1; Wig, Wiggenhall 1; Wis, Wisbech 1; Cof,Cooles Farm 1 (Minety). Tremadocian provings in red: Baf, Barford; CaW, Calvert (West); Cof, Cooles Farm 1 (Minety); CrH, Crown Hills (Evington); Dad, Dadlington; EWh, East Worldham 1; Fow, Fownhope 1; GaF, Gables Farm; HoB, Hollies Barn; LFE, Leicester Forest East; LiL, Lillingstone Lovell; Me2, Merevale No. 2; Mer, Meriden; Ryt, Ryton No. 1; Shw, Shrewton; Tat, Tattenhoe; Tri, Tring (Superior); Tw4, Twyford 4; Wec, Westcott No. 1; Wyb, Wyboston; Yar,Yarnbury.

Fig. 11. Post-Tremadocian Ordovician terrane elements. Caledonian terrane boundaries south of the Iapetus Suture are slightly modified after Bluck (1992) and BGS (1996). Boundary between Lakesman-Leinster Terrane and Wexford-Monian-Ingletonian Terrane ('Irish Sea Horst', and probable Ganderian correlative) following Soper and Dunning (2008). Ordovician outcrop, solid red ornament. For key to major faults and lineaments see Fig. 1.

Fig. 12. A. Boreholes on the Midland Platform with biostratigraphically constrained basement beds, after Molyneux (1991). B. Boreholes in the Anglian Foldbelt with biostratigraphically constrained basement beds, after Molyneux (1991).

Fig. 13. Post-Tremadocian Ordovician outcrop and borehole provings in southern Britain and key localities in Belgium. Base map for UK modified from UCAL (Acadian Unconformity) Map by Nigel Smith (unpublished) and for Belgium, after De Vos et al. (1993). For key to major faults and lineaments see Fig. 1. Outcrop, solid ornament. Key to borehole provings. Tremadocian-Floian provings: Irv, Ironville 5; BeS, Beckermonds Scar; StA, Strat A-1; Wal, Walsall. Dapingian-Darriwillian Provings: Eym, Eyam; GrP, Great Paxton; Hun, Huntingdon (Hill Common); OS 47/29a-1. Sandbian-Katian Provings: Bob, Bobbing; Clx, Claxby 1; CoH, Cottage Homes (Countesthorpe); NCr, North Creake; Pre, Prees 1; StH, Stocks House (Desford). ?Ordovician Provings: BPF, Barron Park Farm; Byf, Byfield; CoW, Cox's Walk; Eak, Eakring 146; GOW, Great Osgrove Wood; HaH, Halton Holegate 1; Hol, Hollowell; HoC, Holme Chapel 1; Irv, Ironville 5; Mil, Milton; MiG, Milton Green 1; GST2, Nassington; SaW, Saffron Walden; Spr, Sproxton 1; GST10, Thornhaugh; TBW, Thorpe-By-Water; Upw, Upwood; Wal, Walsall; Wit, Wittering 1.

Fig. 14. Ordovician and Silurian volcanic sequences proved by boreholes in the British part of the ABM (modified after Pharaoh et al., 1991).

Fig. 15. Silurian outcrop and borehole provings in the British part of the ABM. Base map for UK modified from UCAL (Acadian Unconformity) Map by Nigel Smith (unpublished) and for Belgium, after De Vos et al. (1993). For key to major faults and lineaments see Fig. 1. Outcrop, solid ornament. Key to borehole provings. Llandovery provings: Fow, Fownhope 1; Bat, Batsford (Lower Lemington); 
Bra, Brabourne; Chi, Chilham; Hig, Highworth 1; Sil, Silverdale; StL, Stow Langtoft; Sha, Shalford 1; Shb, Shipbourne; Usk, Usk 1; Wal, Walsall; Som, Somerton 1; Stt, Stutton; Wee, Weeley. Wenlock provings: Bra, Brabourne; CS4, Church Stretton 4; ClM, Cliffe Marshes; Cod, Codsall 1; Sme, Smestow; Usk, Usk 1; Wal, Walsall; War,Ware. Ludlow provings: Cow, Colwall; Low, Lowestoft (Lake); Rec, Reculver. Př́idoli provings: Clr, Clare; Lak, Lakenheath 1; LiM, Little Missenden; Silurian Provings: Bic, Bicester 1; Clv, Claverley; ElF, Ells Farm (Bloxham); Ham, Hamstead. ?Silurian provings: Net, Netherton 1; Bre, Breckles 1; CS2, Cominco S2; Cul, Culford; ERu, East Ruston; Erw, Eriswell 1; Haw, Harwich; IOG, Isle Of Grain; Sax, Saxthorpe 1; She, Sheerness.

Fig. 16. Late Caledonian structure south of the Iapetus Suture superimposed on Acadian subcrop. Modified after Woodcock (2012d), following BGS (1996).

Fig. 17. Caledonian metamorphic grade south of the Iapetus Suture. After Merriman et al. (1993), Merriman (2006) and Woodcock (2012d).

Fig. 18. Late Palaeozoic stratigraphical chart for the northern edge of the Anglo-Brabant Massif (after Pharaoh et al., 2011). System and stage names and ages from the Gradstein et al. (2012).

Fig. 19. Early Devonian outcrop and borehole provings in southern Britain. Base map for UK after UCAL (Acadian Unconformity) Map by Nigel Smith (unpublished) and for Belgium, after De Vos et al. (1993). For key to major faults and lineaments see Fig. 1. Outcrop, solid ornament. Key to Early Devonian borehole provings. GuP, Guiting Power 1; LiC, Little Chishill; StA, Steeple Aston; Roc, Rocklands; Sta, Staverton 1; ApB, Apley Barn; BeG, Beckton Gasworks No. 4; CaI, Canvey Island; Elh, Ellingham 1; Far, Faringdon 1; SoE, Sonning Eye 1; Shb, Shipbourne.

Fig. 20. Schematic illustration of Devonian onlap and overstep onto the Anglo-Brabant Massif. Modified from Woodcock (2012) following Allen (1979). Key to boreholes shown in figure and inset map: 1, Whittington Heath; 2, Merevale No. 2; 3, Soham; 4, Wyboston; 5, Gayton; 6, Steeple Aston; 7, Apley Barn; 8, Turnford; 9, Little Missenden; 10, Bushey; 11, Faringdon; 12, Willesden; 13, Canvey Island; 14, Southall; 15, Tatsfield; 16, Harmansole; 17, Bolney; 18, Brightling. Boxes indicate stratigraphic range.

Fig. 21. Early Carboniferous (Mississippian) structural and stratigraphic elements of the AngloBrabant Massif. Modified from Corfield et al. (1996), Glennie (2005), Waters and Davies (2006), and Davies et al. (2012). Key to abbreviated basin elements: BH, Bowland High; CPH, Central Pennine High; DP, Derbyshire Platform; EB, Edale Basin; GT, Gainsborough Trough; LFB, Lancaster Fells Basin; ML, Malvern Line; MWR, Manx-Whitehaven Ridge; MB, Munster Basin; NSB, North Staffordshire Basin; WG, Widmerpool Gulf; WB, Widnes Basin.

Fig. 22. Early Mississipian (Tournaisian-Visean) structural and stratigraphic elements of the AngloBrabant Massif in the East Midlands (after Pharaoh et al., 2011).

Fig. 23. Latest Mississipian (Namurian) structural elements of central and northern England (after Smith et al., 2005). Sediment transport directions are generalised.

Fig. 24. Schematic distribution of Visean-Namurian sandstones in central and northern England, modified after Hallsworth and Chisholm (2017) and published with permission. Protoquartzitic, southerly derived sandstones coloured blue; feldspathic, northerly derived sandstones, coloured pink.

Fig. 25. Provenance and inferred palaeocurrent directions for Namurian sandstones at the northern margin of the ABM, modified from Hallsworth and Chisholm (2017) and published with permission. Protoquartzitic, southerly derived sandstones coloured blue; feldspathic, northerly derived sandstones, coloured pink. Outline of Widmerpool Half-graben shown by bold dashed line. a. PendleianArnsbergian time, b. Mid Marsdenian time, c. Late Marsdenian time. 
Fig. 26. Distribution of Carboniferous basins at the northern and western margins of the ABM. Exposed geology after BGS 1:625 000 digital mapping; concealed basins after BGS (1999) and Pharaoh et al. (2011). Variscan structures after BGS (1996). For key to major faults and lineaments see Fig. 1. Key: UORS, Upper Old Red Sandstone (Upper Devonian); CL Sgp, Carboniferous Limestone Supergroup (Visean- Tournaisian); MG Gp, Millstone Grit Group (Namurian); L PCM Gp; Lower Pennine Coal Measures Group (Westphalian A); U PCM Gp; Upper Pennine Coal Measures Group (Westphalian B/C); W Gp, Warwickshire Group (Westphalian C/D). Concealed Carboniferous basins in shades of blue.

Fig. 27. Variscan inversion structures surrounding the ABM. Key: Exposed geology after BGS 1:625 000 digital mapping; concealed basins after BGS (1999) and Pharaoh et al. (2011). Variscan structures after BGS (1996). For key to major faults and lineaments see Fig. 1. Key: UORS, Upper Old Red Sandstone (Upper Devonian); CL Sgp, Carboniferous Limestone Supergroup (ViseanTournaisian); MG Gp, Millstone Grit Group (Namurian); L PCM Gp; Lower Pennine Coal Measures Group (Westphalian A); U PCM Gp; Upper Pennine Coal Measures Group (Westphalian B/C); W Gp, Warwickshire Group (Westphalian C/D). Concealed Carboniferous basins in shades of blue.

Fig. 28. Permian-Mesozoic stratigraphic chart for the London Platform (after Pharaoh et al., 2011). System and stage names, and ages, from Gradstein et al. (2012).

Fig. 29. Subcrop limits of key Permian-Mesozoic formations onto the London Platform. Redrawn after Warrington and Ivimey-Cook (1992), Bradshaw et al. (1992) and Hancock and Rawson (1992). Some locational uncertainty results from the variable amount of post-depositional erosion, schematically indicated by the grey arrows on Fig. 30. Key to codes: T2, Mid Triassic (latest Anisian); T3, Late Triassic (Early Rhaetian); J1, Early Jurassic (Early Hettangian); J3, Early Jurassic (Mid Toarcian); J4a, Mid Jurassic (Early Aalenian); J5, Mid Jurassic (Early Bajocian); J9, Late Jurassic (Mid Oxfordian); J11a, Late Jurassic (Early Portlandian); K2b, Early Cretaceous (Late Albian); K3, Early Cretaceous (latest Aptian).

Fig. 30. Onlap and regression of Jurassic sequences onto the London Platform in East Anglia. After A.J.M. Barron in Lee et al. (2015). Arrows schematically indicate pre-erosional extent of formation.

Fig. 31. Cross section N-S across the Wessex Basin, London-Brabant Platform and Eastern England Shelf showing relationship of major Permian-Mesozoic sequences onlapping onto the platform. Modified from Whittaker (1985). Location shown as section A on Inset Map.

Fig. 32. Cross section N-S across the London-Brabant Platform, showing relationship of TriassicJurassic sequences and overstep by the late Cretaceous. Location shown as section B in Inset Map of Fig. 31. 


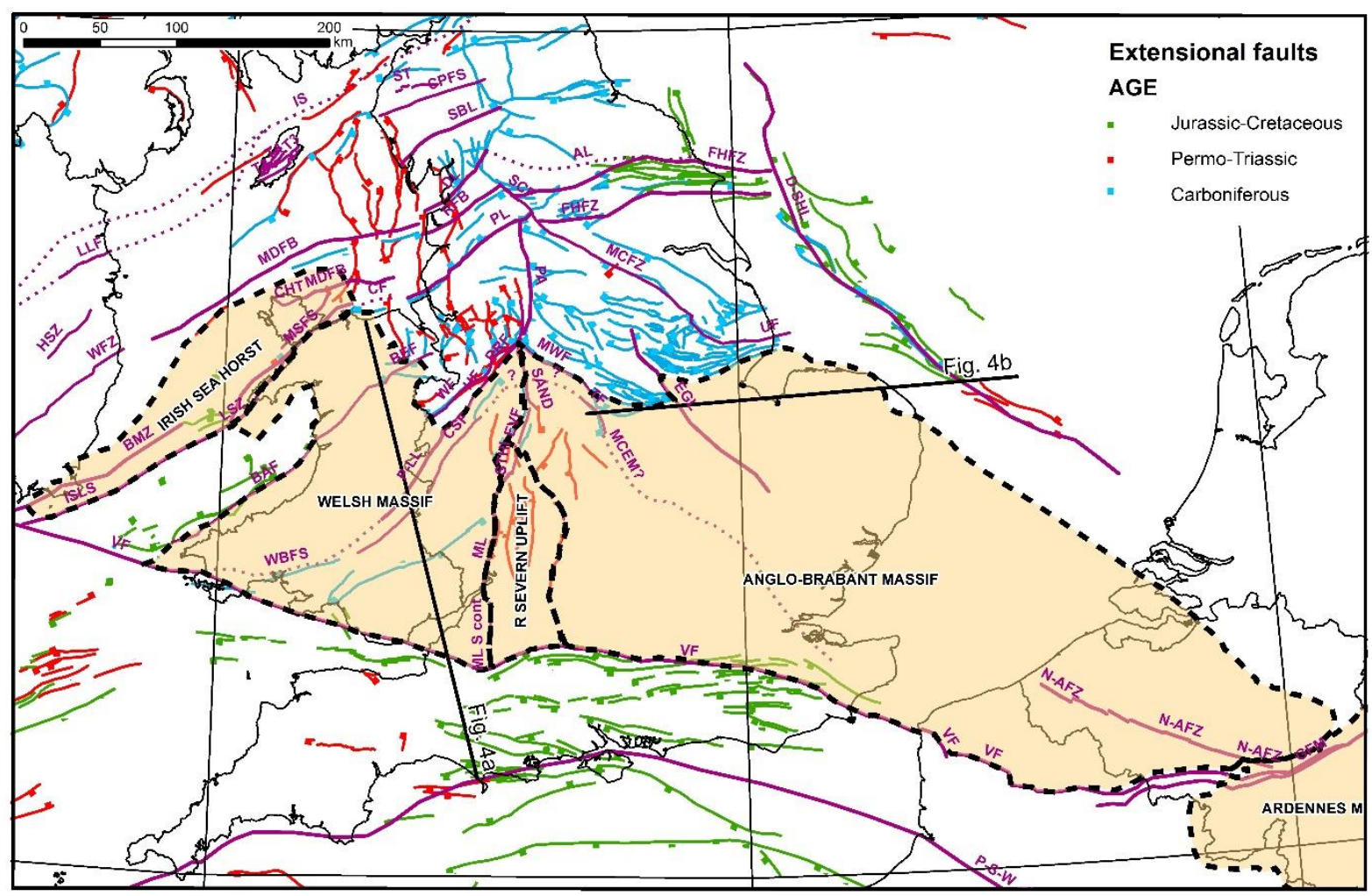

Fig. 1 


\begin{tabular}{|c|c|c|c|c|c|}
\hline AGE/EVENT & $\begin{array}{l}\text { WALES \& } \\
\text { BORDERS }\end{array}$ & $\begin{array}{l}\text { WORCESTER } \\
\text { BASIN }\end{array}$ & $\begin{array}{l}\text { MIDLAND } \\
\text { MASSIF }\end{array}$ & $\begin{array}{l}\text { E ANGLIAN } \\
\text { MASSIF }\end{array}$ & BRABANT MASSIF \\
\hline ALPINE OROGENY & $\begin{array}{l}\text { UPLIFT (IRISH } \\
\text { SEA) }\end{array}$ & ?INVERSION & $?$ & $?$ & $\begin{array}{l}\text { SUBSIDENCE } \\
\text { (NORTH SEA) }\end{array}$ \\
\hline $\begin{array}{l}\text { CRETACEOUS- } \\
\text { CENOZOIC }\end{array}$ & WELSH MASSIF & $\begin{array}{l}\text { THERMAL } \\
\text { SUBSIDENCE }\end{array}$ & $\begin{array}{l}\text { THERMAL } \\
\text { SUBSIDENCE }\end{array}$ & $\begin{array}{l}\text { THERMAL } \\
\text { SUBSIDENCE }\end{array}$ & $\begin{array}{l}\text { ?THERMAL } \\
\text { SUBSIDENCE }\end{array}$ \\
\hline $\begin{array}{l}\text { JURASSIC-EARLY } \\
\text { CRETACEOUS }\end{array}$ & WELSH MASSIF & $\begin{array}{l}\text { WORCESTER } \\
\text { GRABEN }\end{array}$ & $\begin{array}{l}\text { LONDON- } \\
\text { BRABANT } \\
\text { PLATFORM }\end{array}$ & $\begin{array}{l}\text { LONDON- } \\
\text { BRABANT } \\
\text { PLATFORM }\end{array}$ & $\begin{array}{l}\text { LONDON- } \\
\text { BRABANT } \\
\text { PLATFORM }\end{array}$ \\
\hline TRIASSIC & WELSH MASSIF & $\begin{array}{l}\text { WORCESTER } \\
\text { GRABEN } \\
\text { EXTENSION }\end{array}$ & $\begin{array}{l}\text { LONDON- } \\
\text { BRABANT } \\
\text { PLATFORM }\end{array}$ & $\begin{array}{l}\text { LONDON- } \\
\text { BRABANT } \\
\text { PLATFORM } \\
\end{array}$ & $\begin{array}{l}\text { LONDON- } \\
\text { BRABANT } \\
\text { PLATFORM }\end{array}$ \\
\hline PERMIAN & WELSH MASSIF & $\begin{array}{l}\text { WORCESTER } \\
\text { GRABEN } \\
\text { EXTENSION }\end{array}$ & $\begin{array}{l}\text { LONDON- } \\
\text { BRABANT } \\
\text { PLATFORM }\end{array}$ & $\begin{array}{l}\text { LONDON- } \\
\text { BRABANT } \\
\text { PLATFORM }\end{array}$ & $\begin{array}{l}\text { LONDON- } \\
\text { BRABANT } \\
\text { PLATFORM }\end{array}$ \\
\hline $\begin{array}{l}\text { VARISCAN } \\
\text { OROGENY }\end{array}$ & $\begin{array}{l}\text { MODERATE } \\
\text { INVERSION }\end{array}$ & $\begin{array}{l}\text { STRONG } \\
\text { INVERSION } \\
\text { RIVER SEVERN } \\
\text { UPLIFT }\end{array}$ & FLEXURE & $\begin{array}{l}\text { ?MINOR } \\
\text { INVERSION }\end{array}$ & ?INVERSION \\
\hline CARBONIFEROUS & WELSH MASSIF & $\begin{array}{l}\text { ?ANGLO- } \\
\text { BRABANT } \\
\text { MASSIF } \\
\end{array}$ & $\begin{array}{l}\text { ANGLO- } \\
\text { BRABANT } \\
\text { MASSIF } \\
\end{array}$ & $\begin{array}{l}\text { ANGLO-BRABANT } \\
\text { MASSIF }\end{array}$ & $\begin{array}{l}\text { ANGLO-BRABANT } \\
\text { MASSIF }\end{array}$ \\
\hline LATE DEVONIAN & $\begin{array}{l}\text { ST GEORGE'S } \\
\text { LAND }\end{array}$ & $\begin{array}{l}\text { ?ANGLO- } \\
\text { BRABANT } \\
\text { MASSIF } \\
\end{array}$ & $\begin{array}{l}\text { ANGLO- } \\
\text { BRABANT } \\
\text { MASSIF } \\
\end{array}$ & $\begin{array}{l}\text { ANGLO-BRABANT } \\
\text { MASSIF }\end{array}$ & $\begin{array}{l}\text { ANGLO-BRABANT } \\
\text { MASSIF }\end{array}$ \\
\hline $\begin{array}{l}\text { LATE CALEDONIAN } \\
\text { OROGENY }\end{array}$ & $\begin{array}{l}\text { WELSH SLATE } \\
\text { BELT }\end{array}$ & $\begin{array}{l}\text { MIDLAND } \\
\text { MICROCRATON }\end{array}$ & $\begin{array}{l}\text { MIDLAND } \\
\text { MICROCRATON }\end{array}$ & $\begin{array}{l}\text { ANGLO-BRABANT } \\
\text { DEFORMATION } \\
\text { BELT }\end{array}$ & $\begin{array}{l}\text { ANGLO-BRABANT } \\
\text { DEFORMATION } \\
\text { BELT }\end{array}$ \\
\hline SILURIAN & $\begin{array}{l}\text { BASIN - } \\
\text { POWYS MS }\end{array}$ & $\begin{array}{l}\text { MIDLAND } \\
\text { PLATFORM } \\
\text { ?RHEIC ARC }\end{array}$ & $\begin{array}{l}\text { MIDLAND } \\
\text { PLATFORM } \\
\text { ?RHEIC ARC }\end{array}$ & BASIN - MS3 & $\begin{array}{l}\text { BASIN - } \\
\text { REBECQ GP }\end{array}$ \\
\hline SHELVEIAN PHASE & $\begin{array}{l}\text { DEXTRAL STRIKE } \\
\text { SLIP FAULTING }\end{array}$ & $\begin{array}{l}\text { NOT } \\
\text { RECOGNISED }\end{array}$ & $\begin{array}{l}\text { NOT } \\
\text { RECOGNISED }\end{array}$ & NOT RECOGNISED & $\begin{array}{l}\text { NOT } \\
\text { RECOGNISED }\end{array}$ \\
\hline $\begin{array}{l}\text { MID TO LATE } \\
\text { ORDOVICIAN }\end{array}$ & $\begin{array}{l}\text { AVALONIAN ARC } \\
\text { TO BACK-ARC - } \\
\text { GWYNED MS }\end{array}$ & $\begin{array}{l}\text { NO SEQUENCE } \\
\text { PRESERVED }\end{array}$ & $\begin{array}{l}\text { NO SEQUENCE } \\
\text { PRESERVED }\end{array}$ & BASIN - MS2 & $\begin{array}{l}\text { BASIN - REBECQ } \\
\text { GP }\end{array}$ \\
\hline $\begin{array}{l}\text { PENOBSCOTIAN } \\
\text { PHASE }\end{array}$ & $\begin{array}{l}\text { ACCRETION OF } \\
\text { MONIAN } \\
\text { TERRANES }\end{array}$ & $\begin{array}{l}\text { NOT } \\
\text { RECOGNISED }\end{array}$ & FOLDING & ?UNCONFORMITY & $\begin{array}{l}\text { DISCONFORMITY } \\
\text { - MAJOR HIATUS }\end{array}$ \\
\hline $\begin{array}{l}\text { CAMBRIAN- } \\
\text { TREMADOCIAN }\end{array}$ & $\begin{array}{l}\text { BASIN - } \\
\text { DYFED MS }\end{array}$ & $\begin{array}{l}\text { WORCESTER } \\
\text { PROTO- } \\
\text { GRABEN }\end{array}$ & $\begin{array}{l}\text { MIDLAND } \\
\text { PLATFORM }\end{array}$ & BASIN - MS1 & $\begin{array}{l}\text { BASIN - } \\
\text { HALLE \& } \\
\text { OTTIGNIES GPS }\end{array}$ \\
\hline EDIACARAN & $\begin{array}{l}\text { CYMRU } \\
\text { \&WREKIN } \\
\text { TERRANES }\end{array}$ & $\begin{array}{l}\text { CHARNWOOD } \\
\text { TERRANE }\end{array}$ & $\begin{array}{l}\text { CHARNWOOD } \\
\text { TERRANE }\end{array}$ & $\begin{array}{l}\text { FENLAND } \\
\text { TERRANE }\end{array}$ & NOT RECOGNISED \\
\hline
\end{tabular}

Fig. 2 

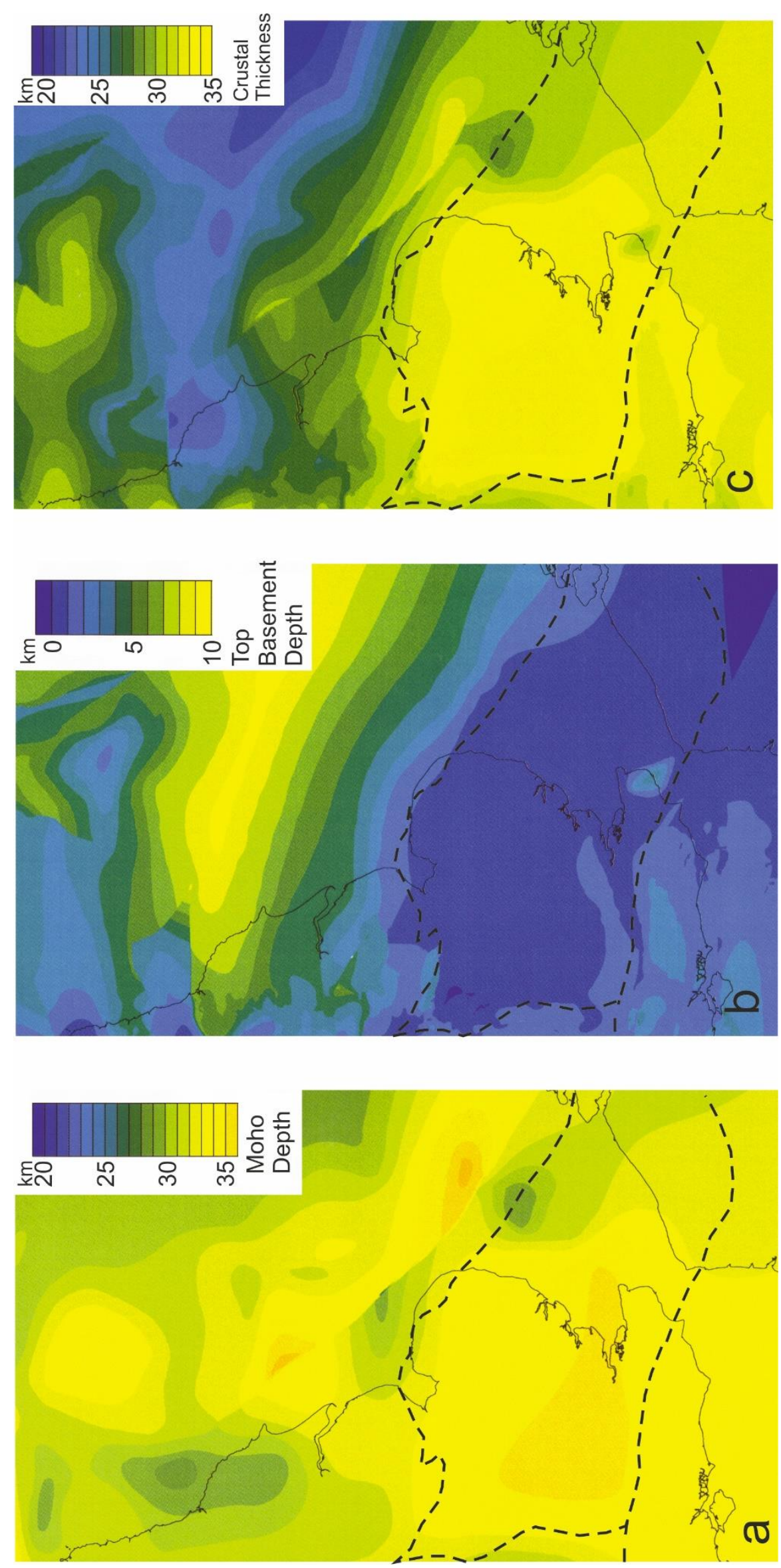

Fig. 3 


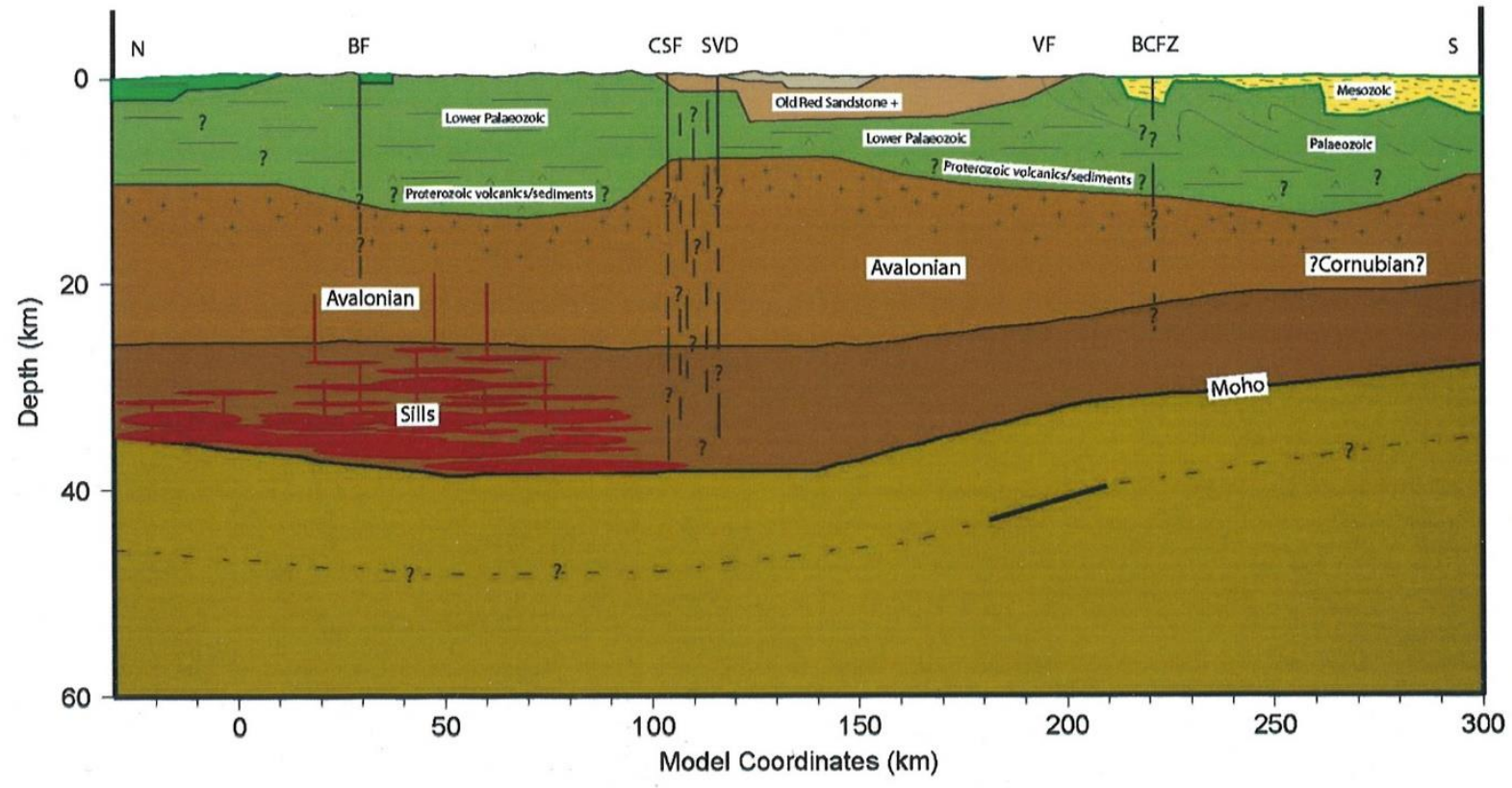

Fig.4a

WEST

EAST MIDLANDS

THRINGSTONE

THULT

${ }^{\text {FA }}$
EAST ANGLIA

LONDON-BRABANT DEFORMATION BELT xtending
urope)
ACADIAN
UNCONFOR
(MIT (Mid Devonian)
EAST

SOUTHERN NORTH SEA

DOWSING-SOUTH THOR SUTURE HEWETT FAULT ZONE

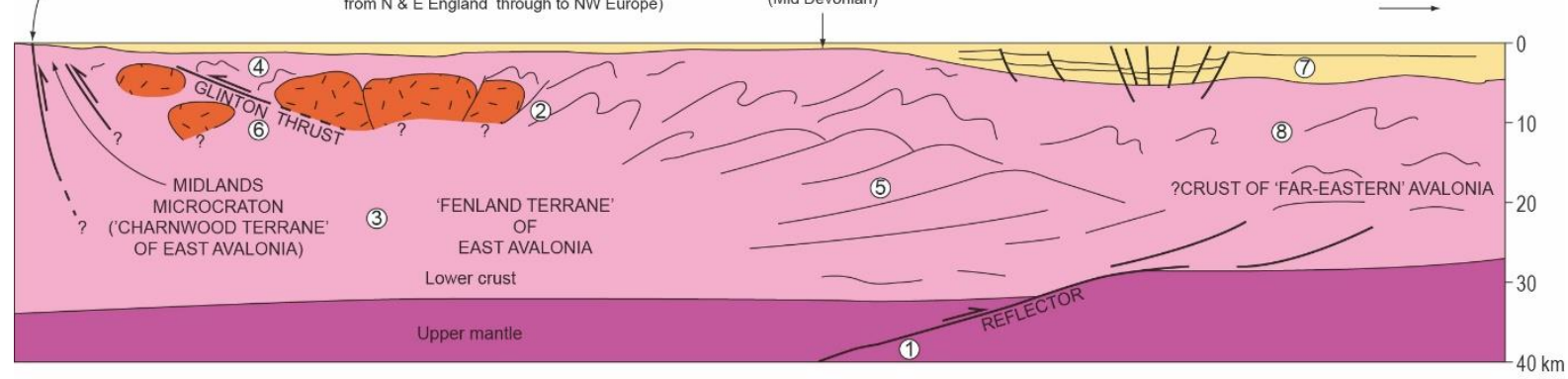

$50 \mathrm{~km}$

Fig. 4b 


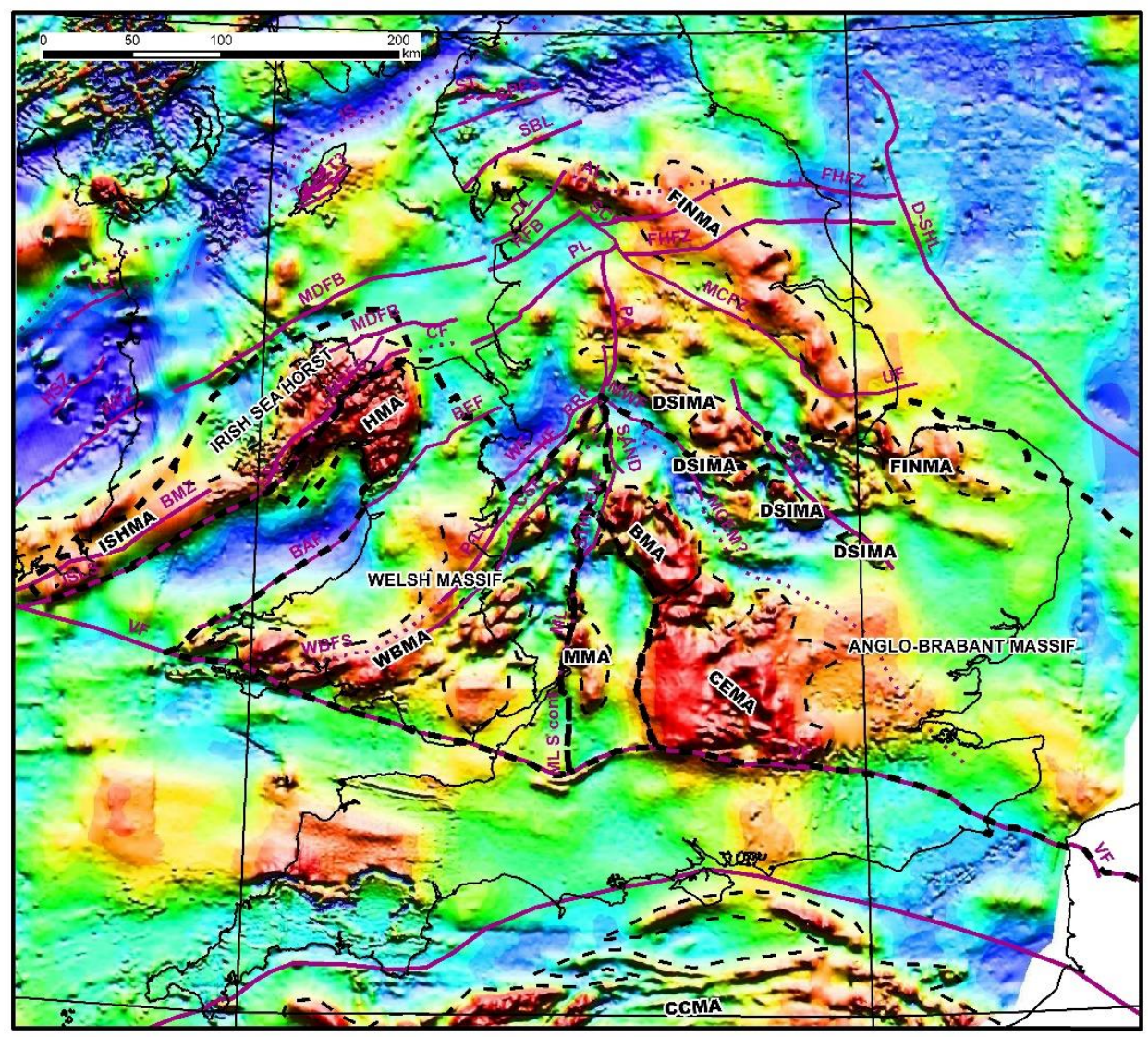

Fig. 5a

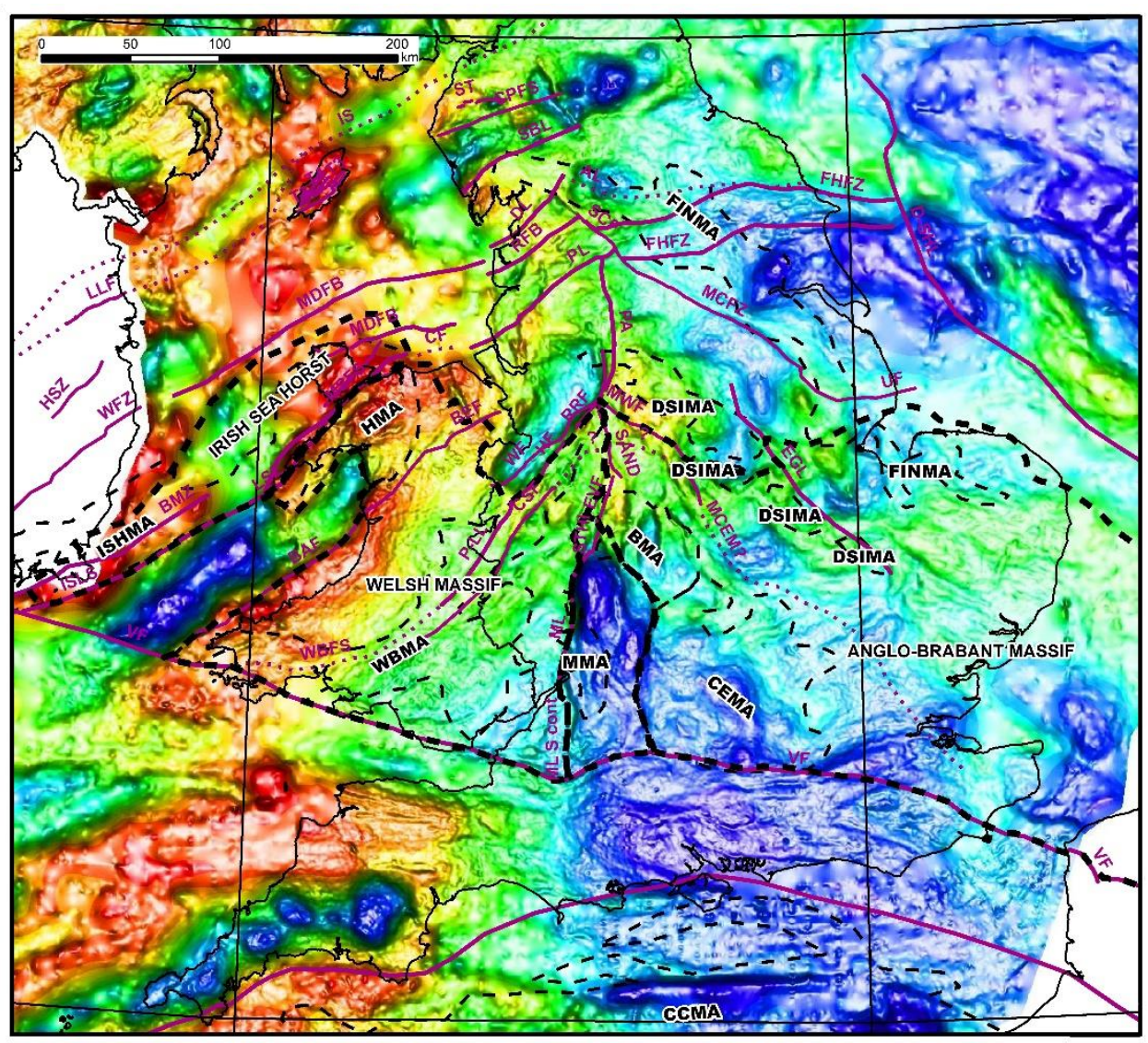

Fig.5b 

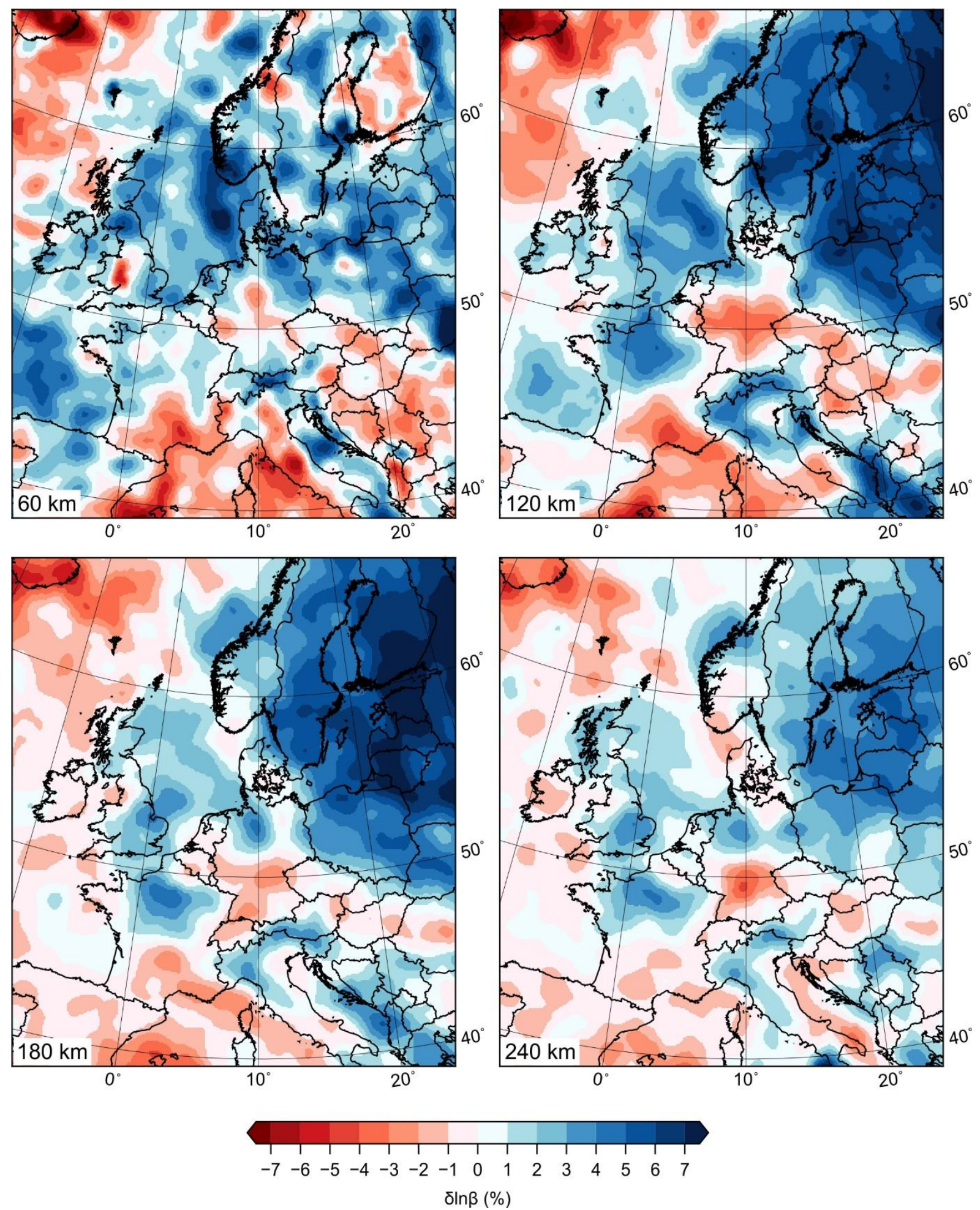

Fig. 6 


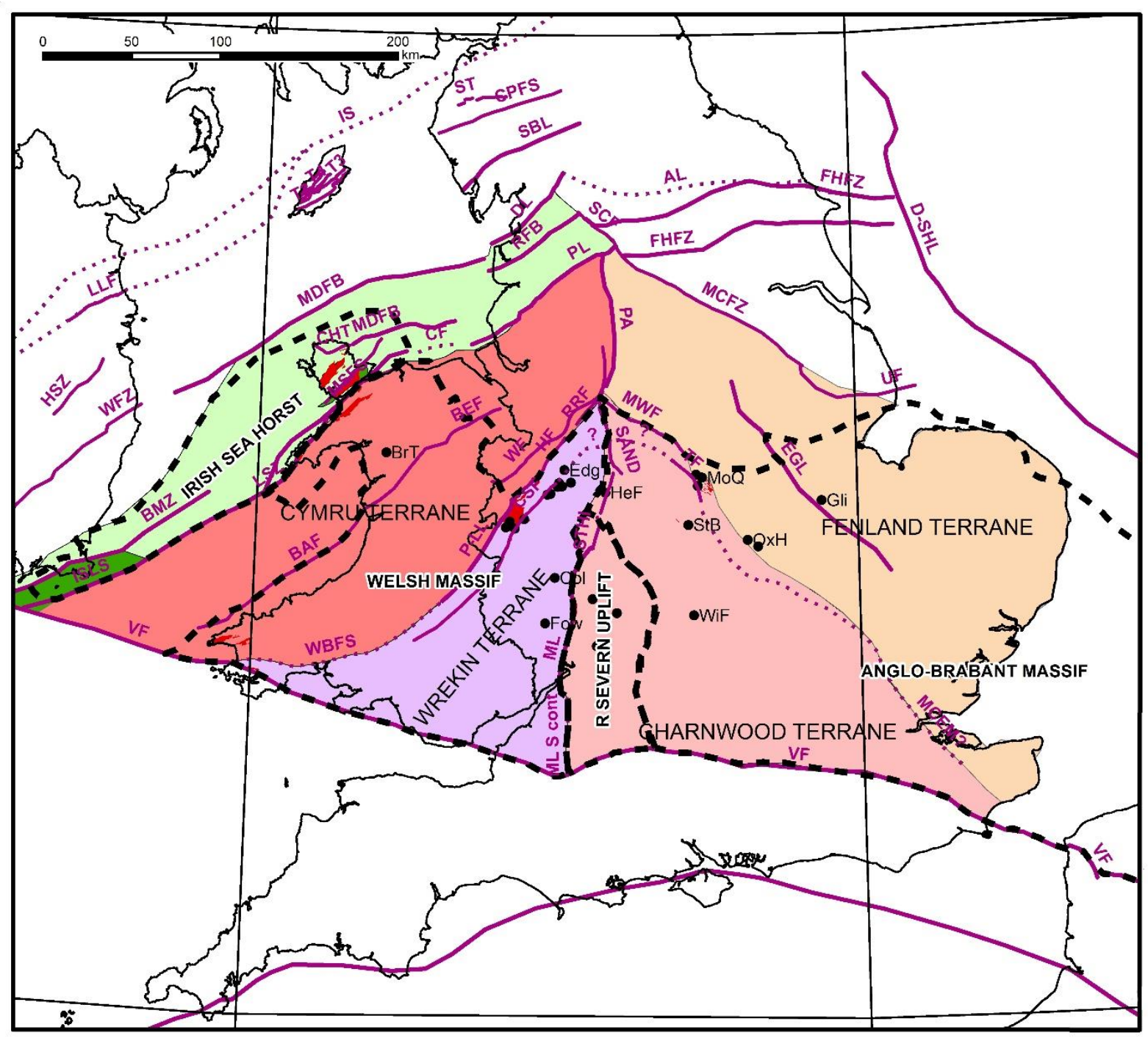

Fig. 7 
a Early Ordovician

$480 \mathrm{Ma}$

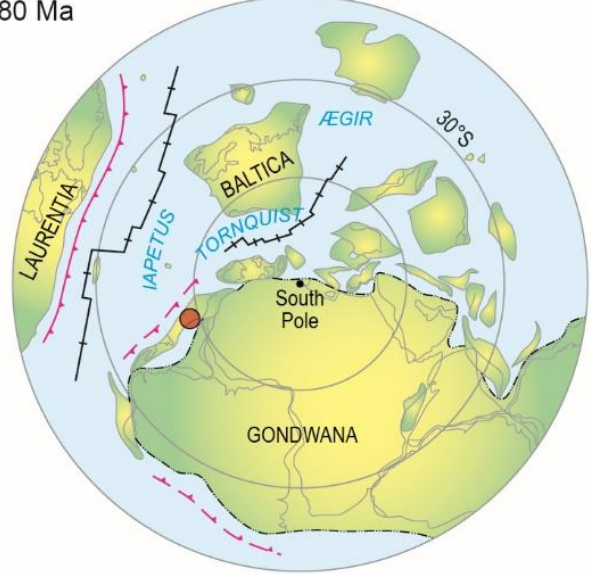

C Late Ordovician

$440 \mathrm{Ma}$

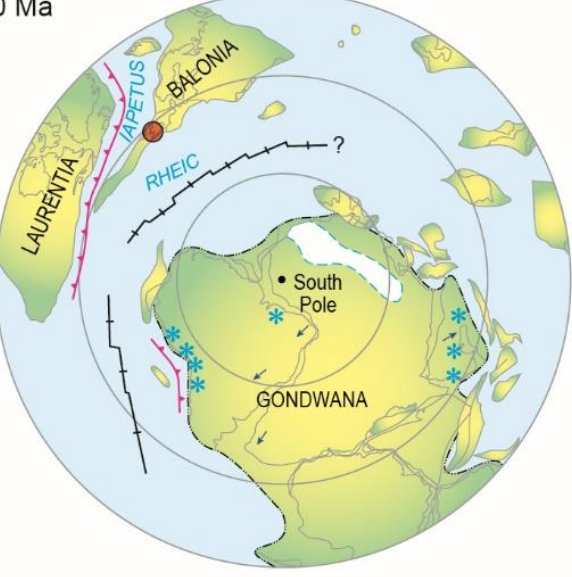

_. Glacial deposits in North Africa

* Glacial dropstones, tillite etc.

- Glacial deposits with ice directions

\section{e Early Devonian}

$400 \mathrm{Ma}$

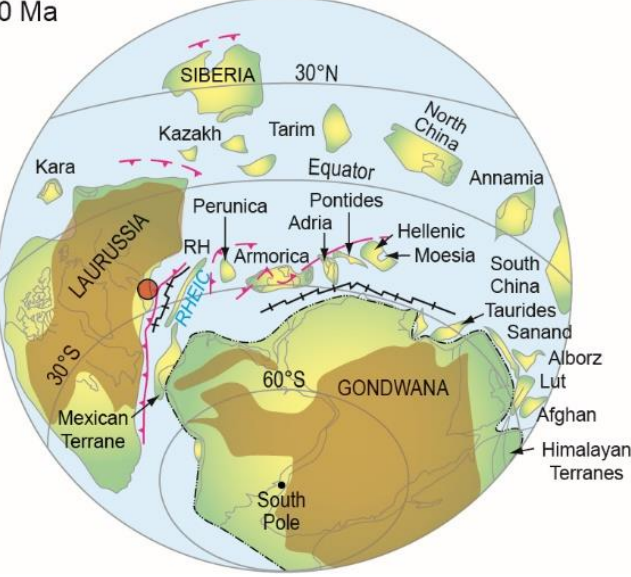

Fig. 8 b Mid Ordovician

$460 \mathrm{Ma}$

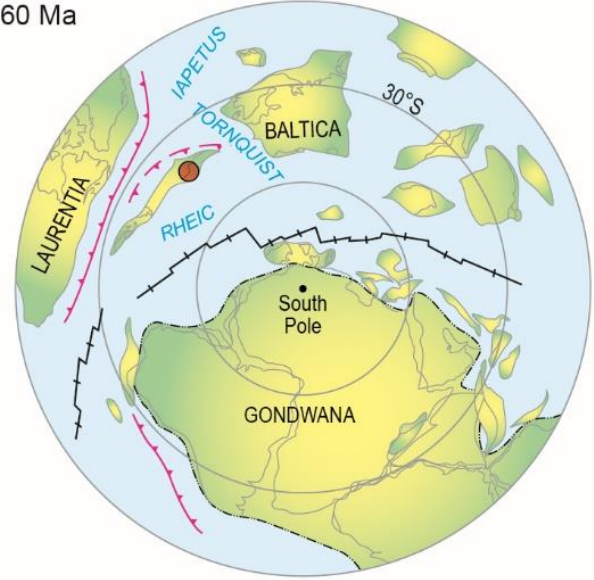

d Late Silurian

$420 \mathrm{Ma}$

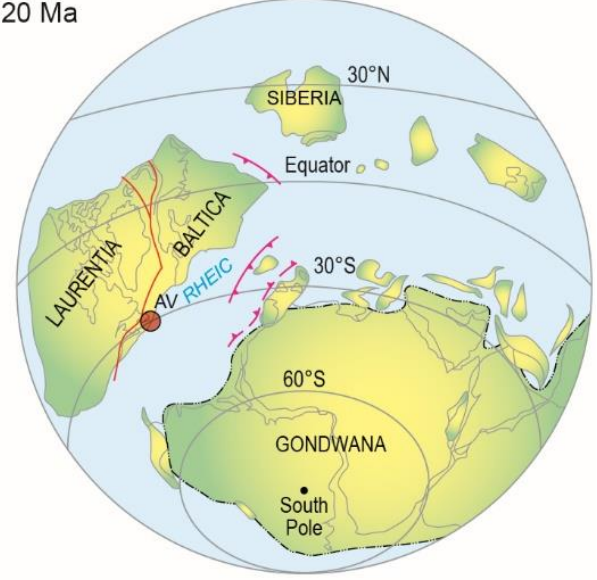

f Early Carboniferous

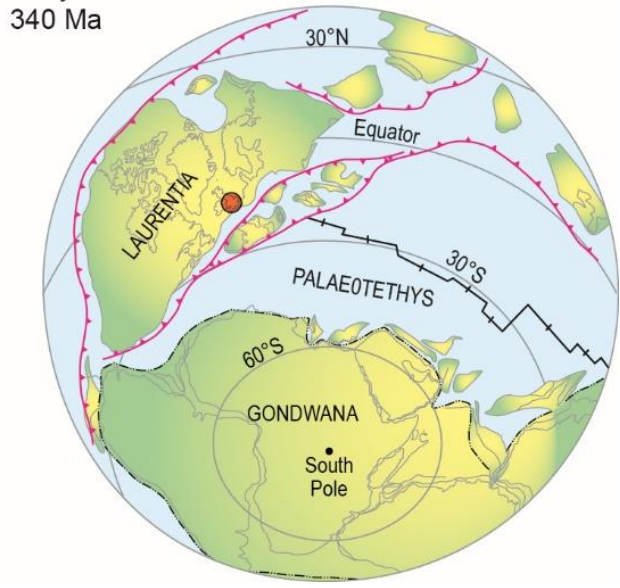




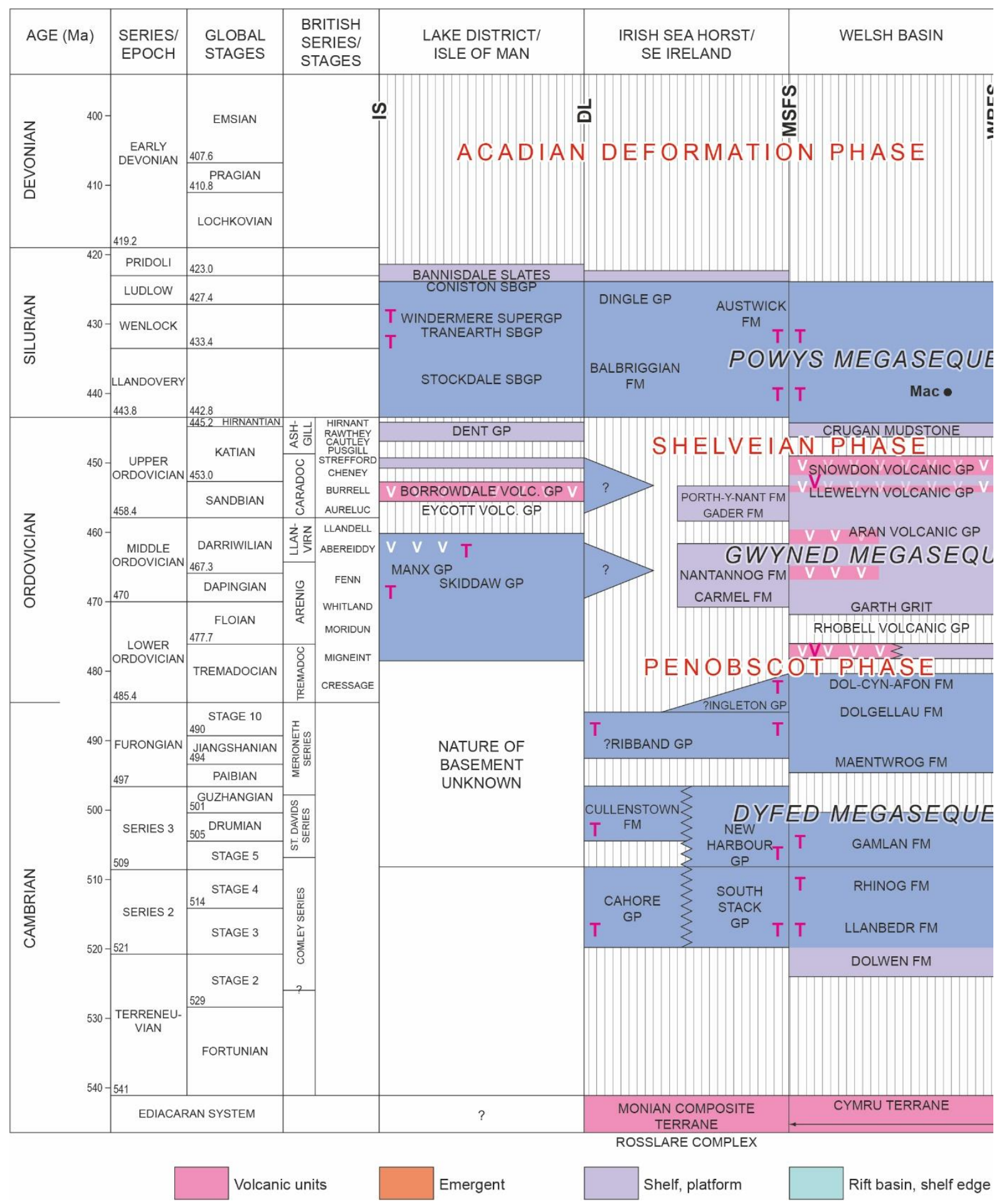

Fig. 9L (Left hand side of 2 page spread) 


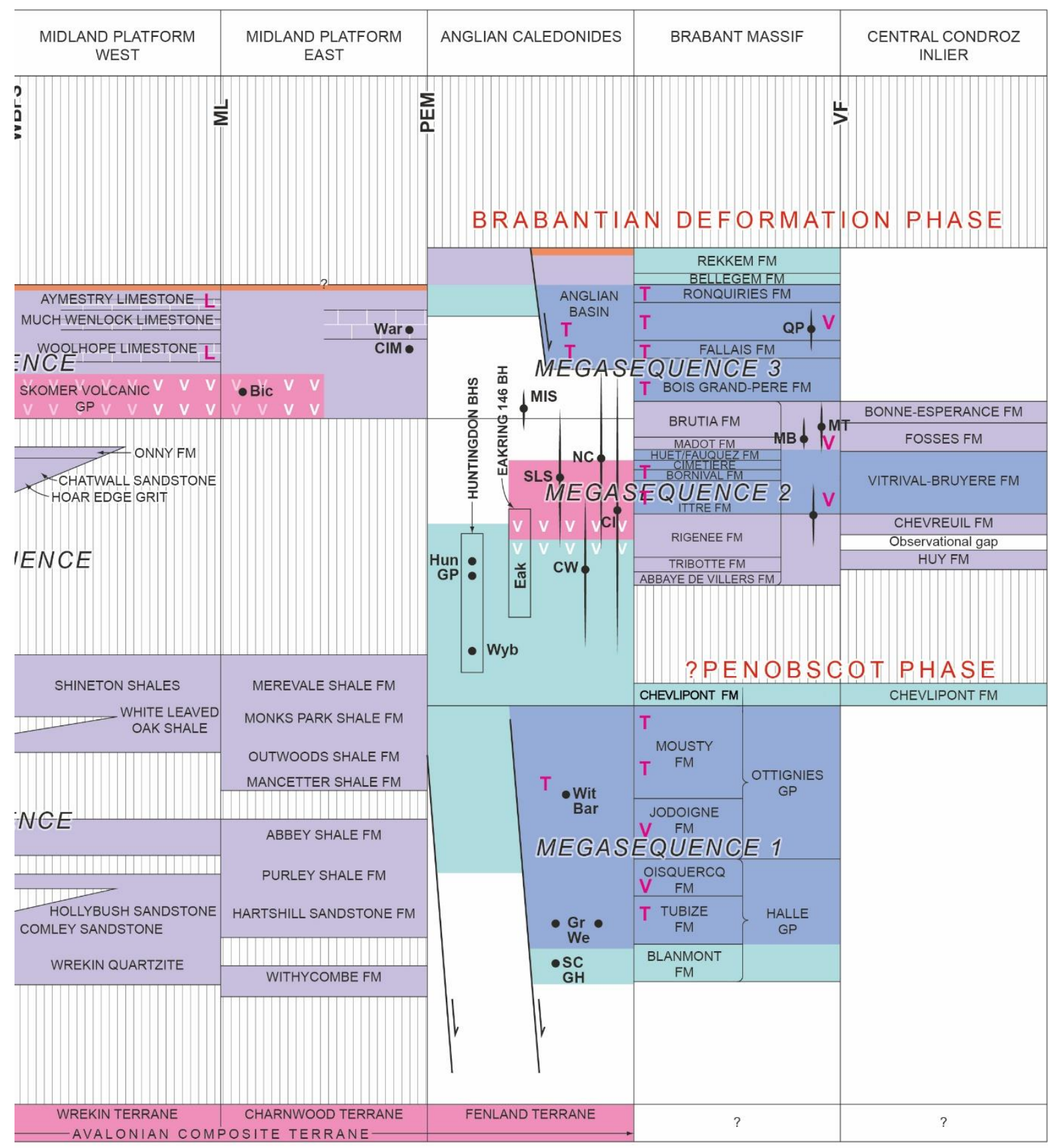

\begin{tabular}{l|l|l|lllllll}
\hline Deep water, basinal & & & Stratigraphic hiatus & T & Turbidites & V & Volcanic rocks & L & Limestone
\end{tabular}

Fig. 9R (Right hand side of 2 page spread) 


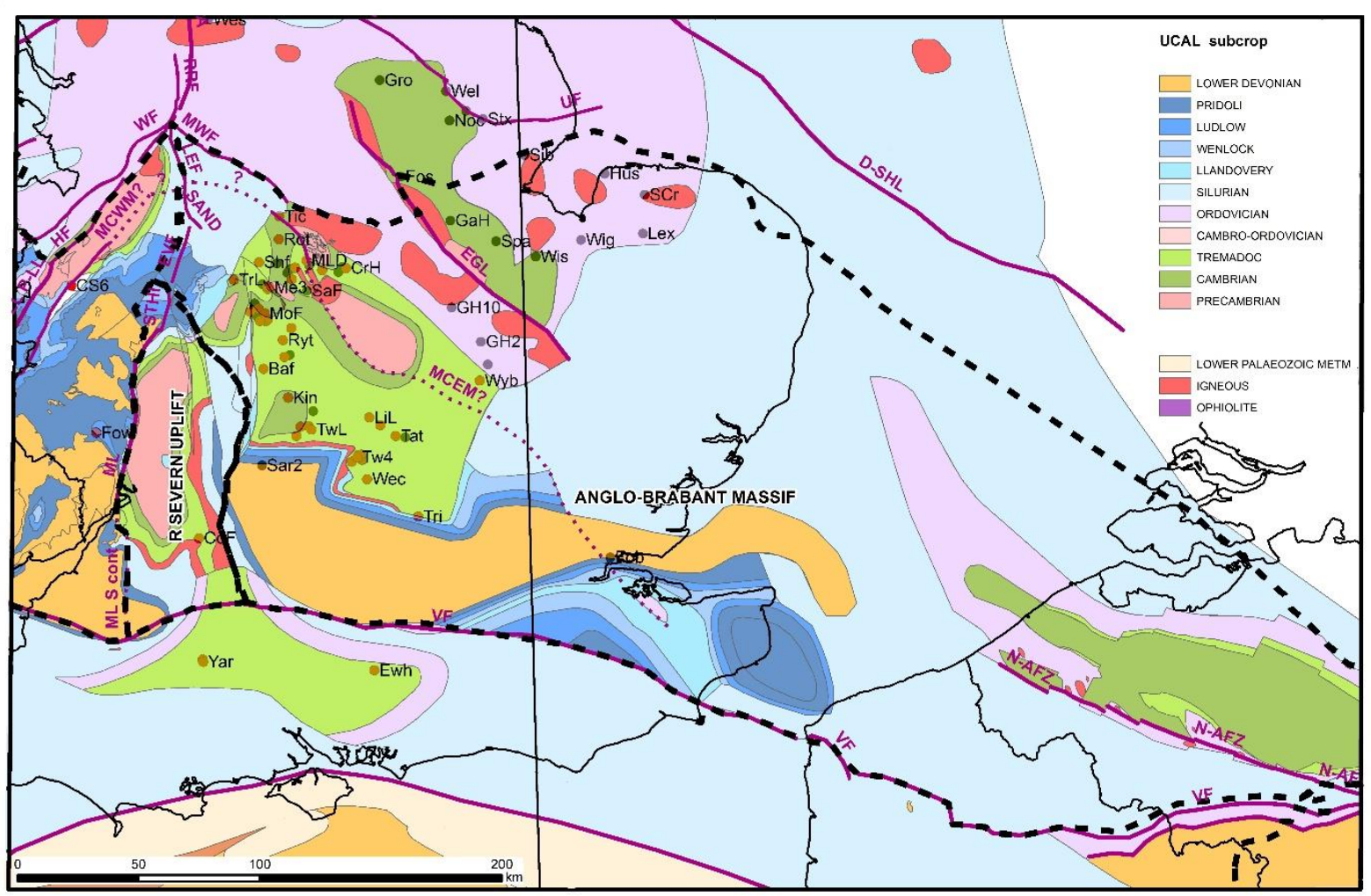

Fig.10

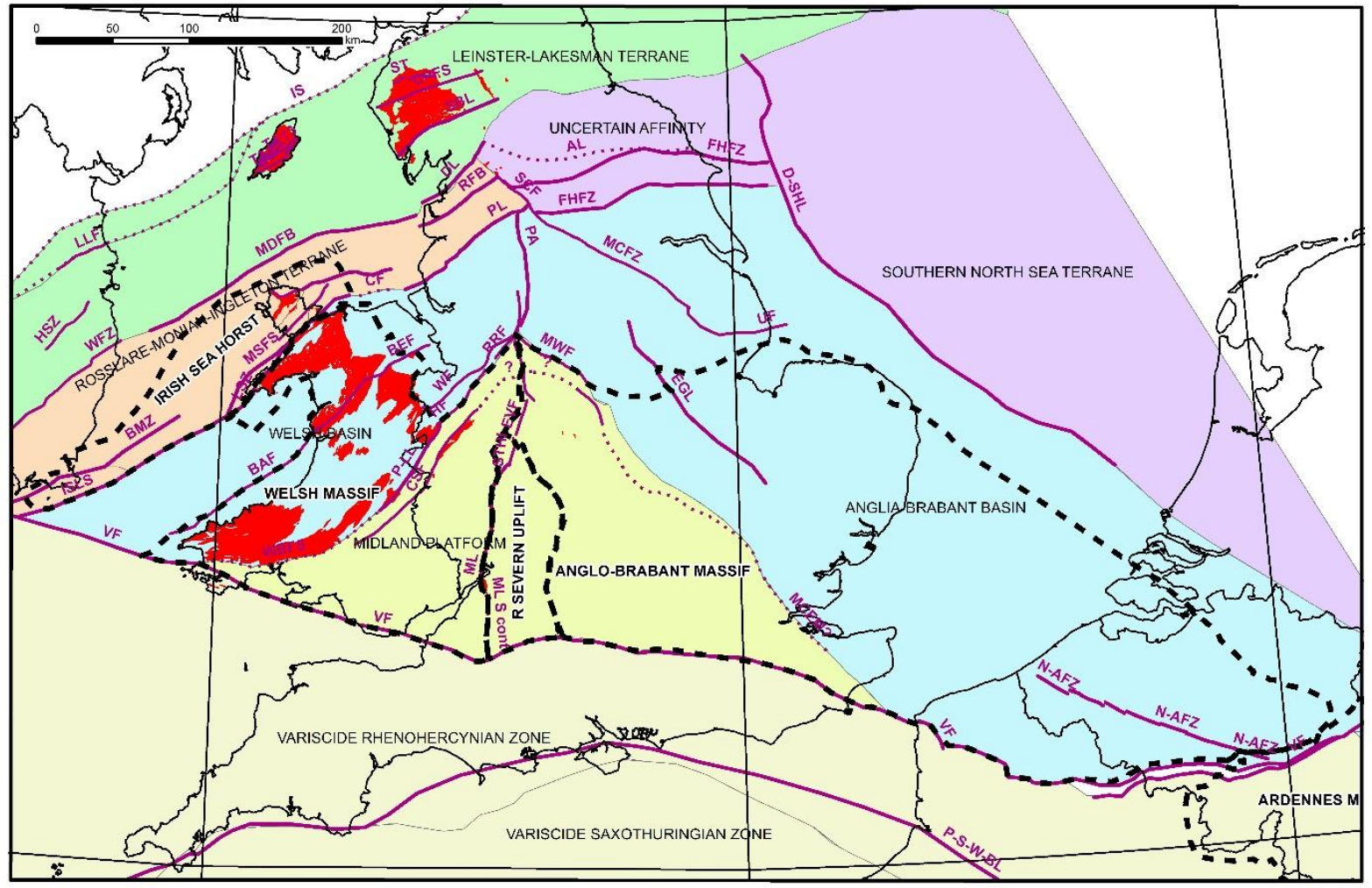

Fig.11 


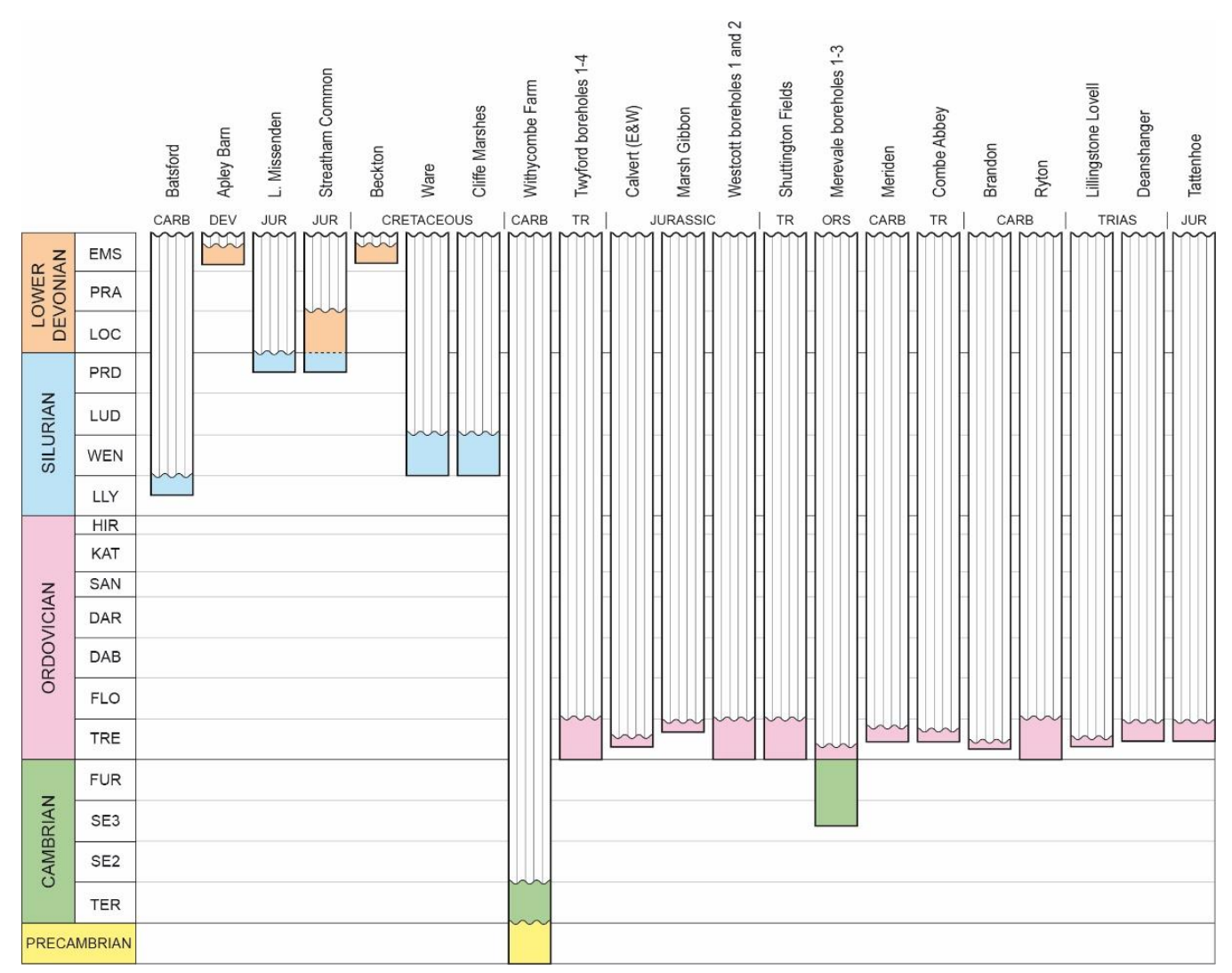

Fig. 12a

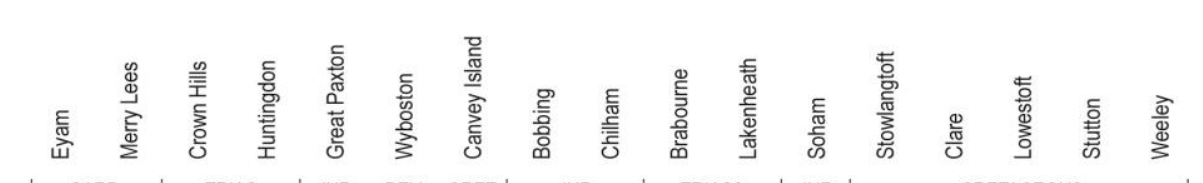

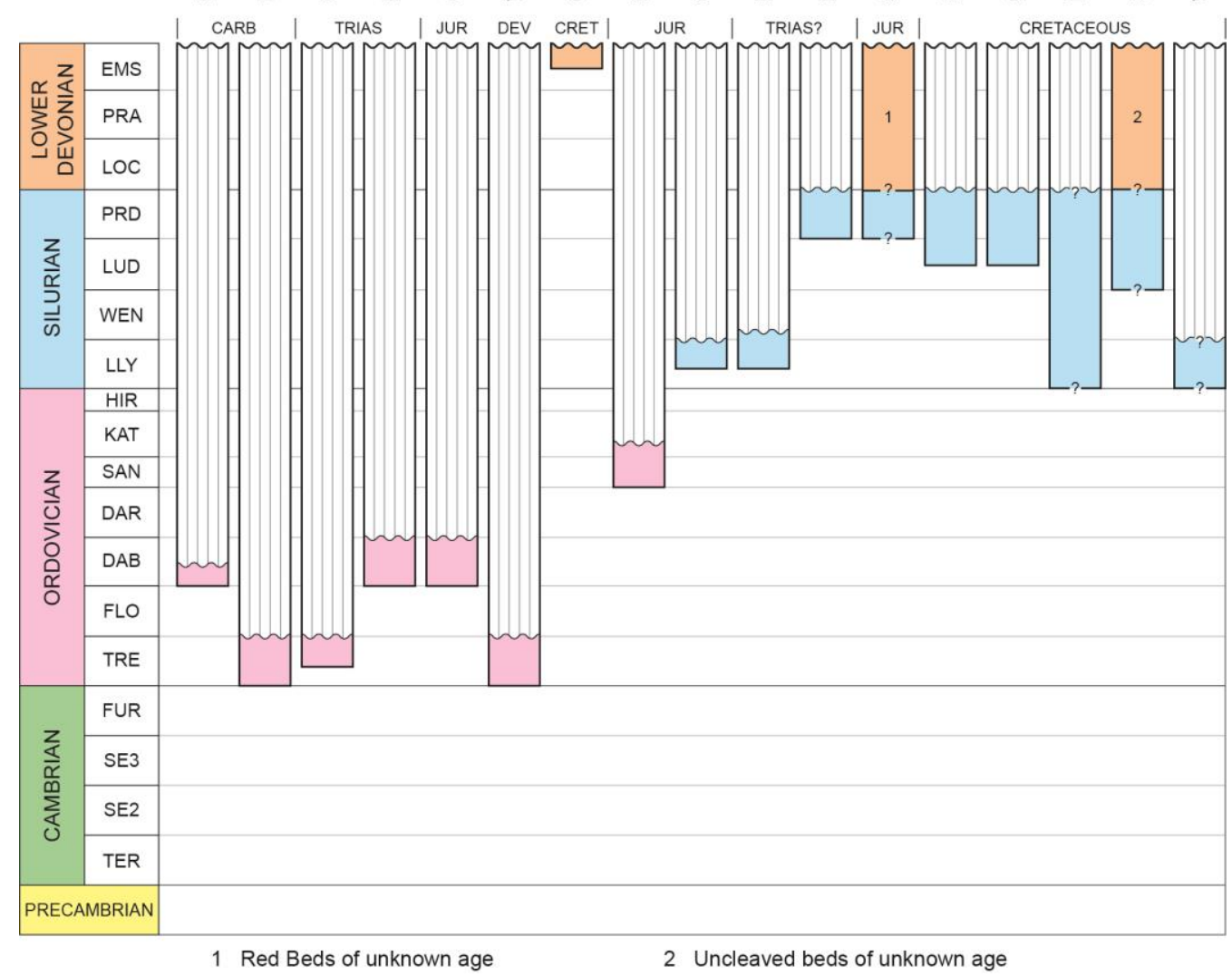

Fig. 12b 


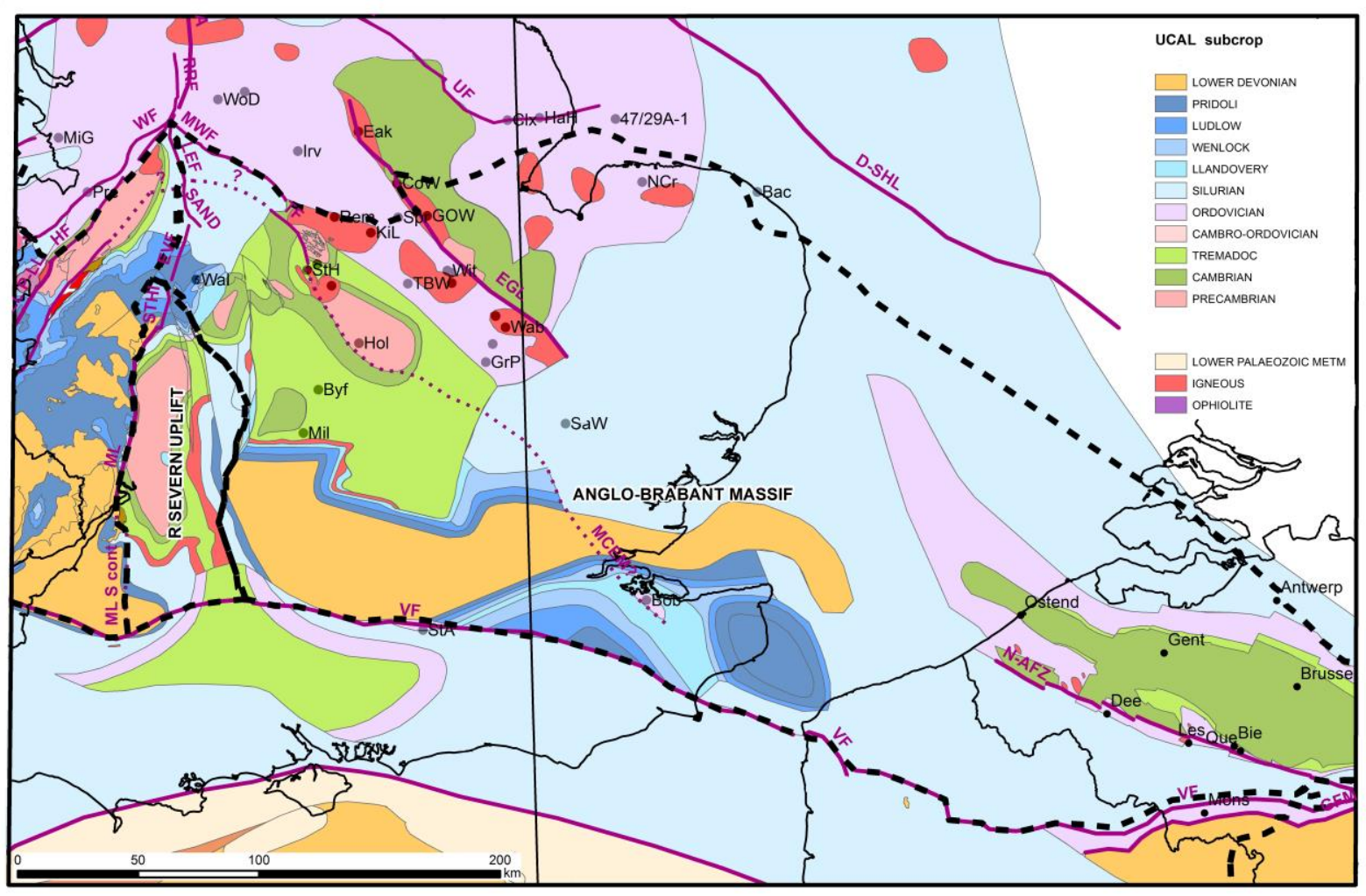

Fig. 13 


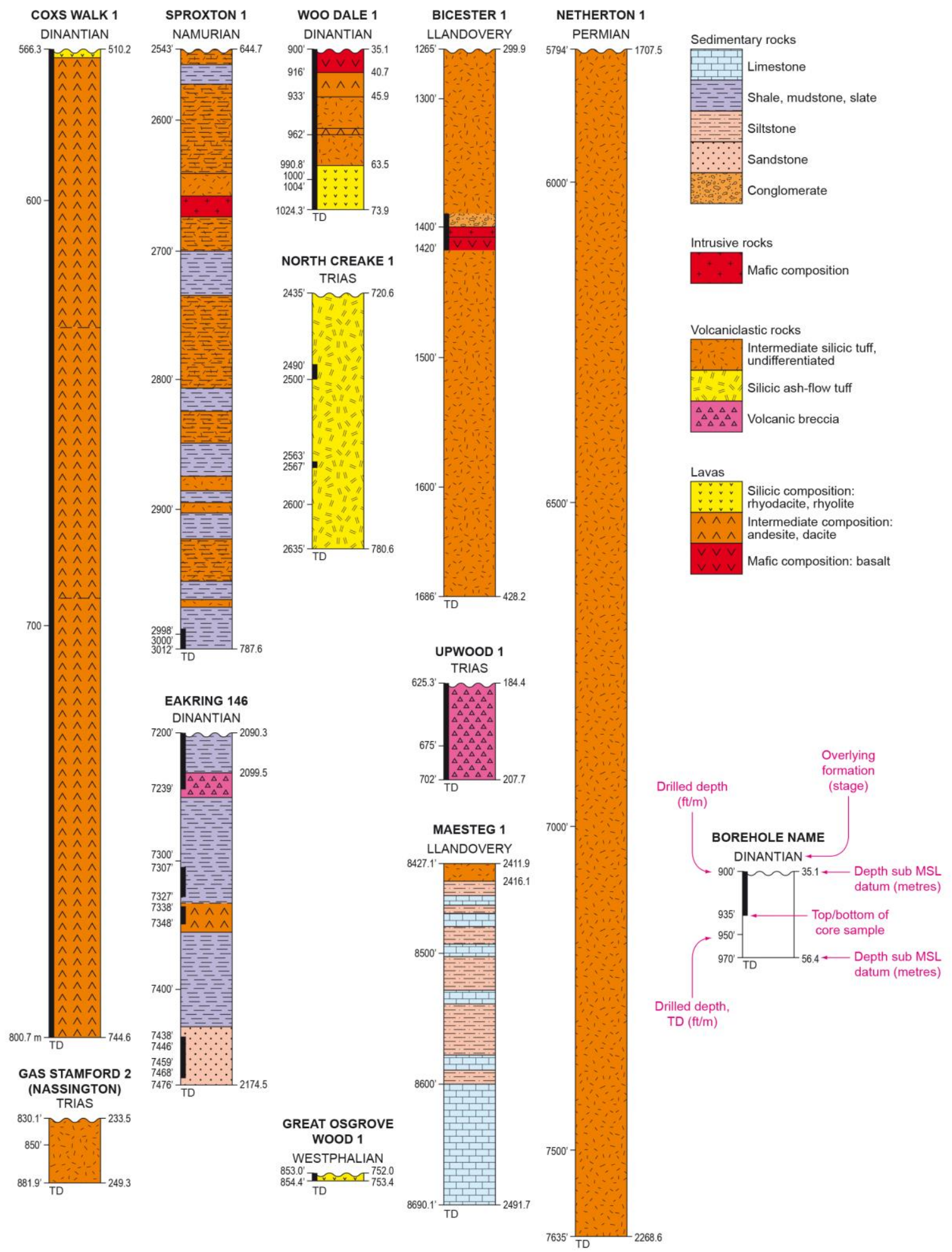

Fig. 14 


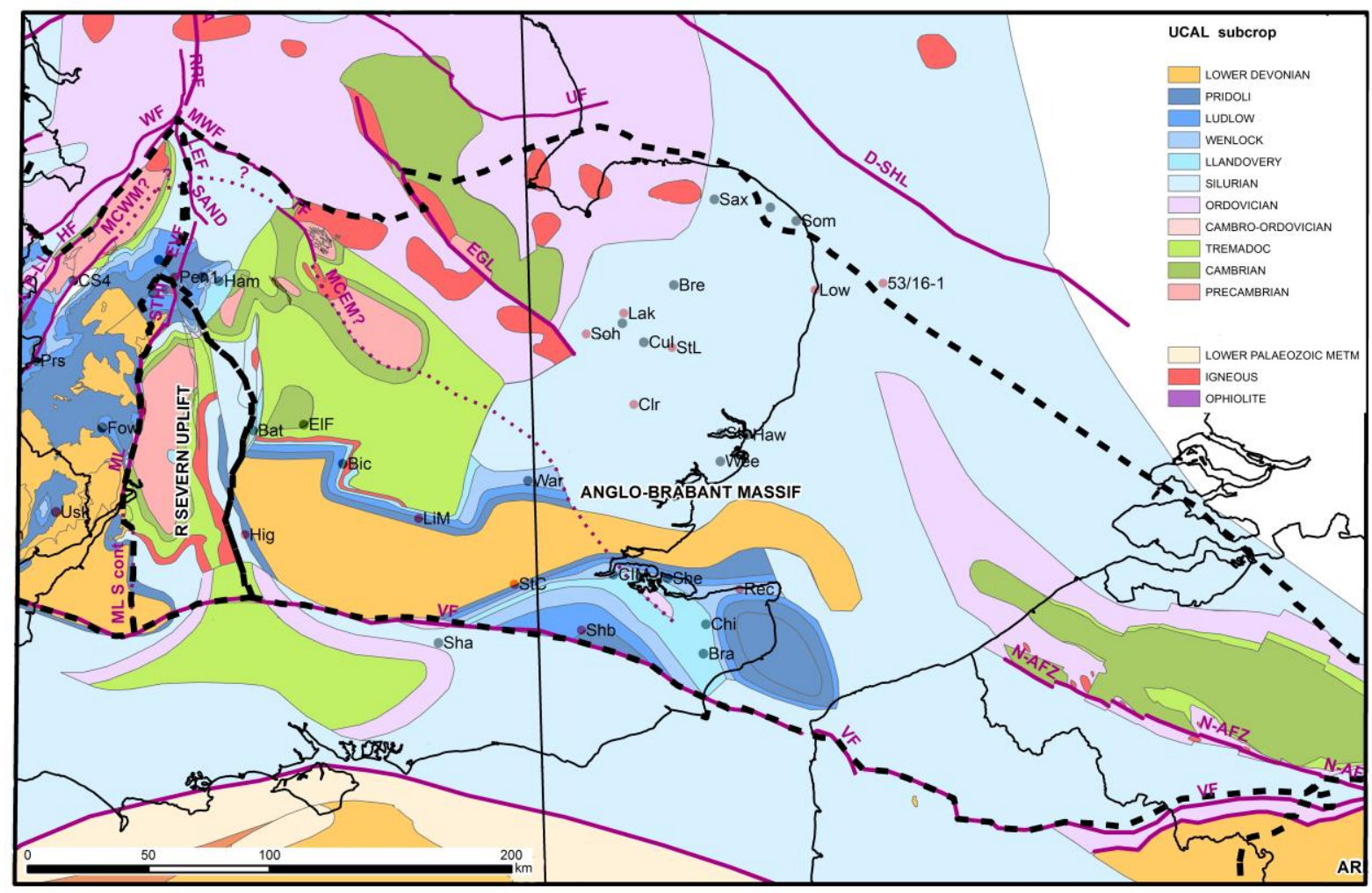

Fig. 15 


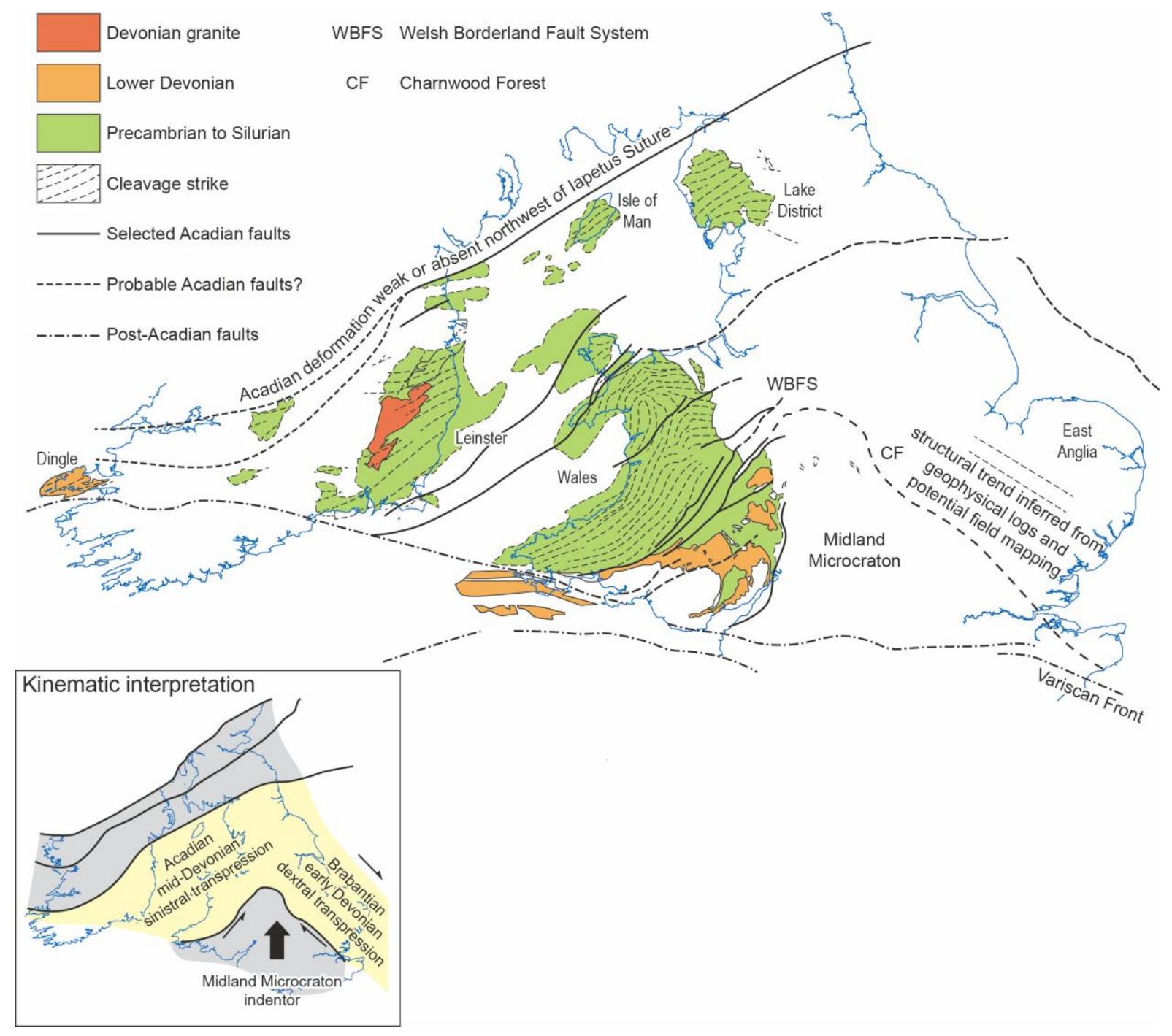

Fig. 16 


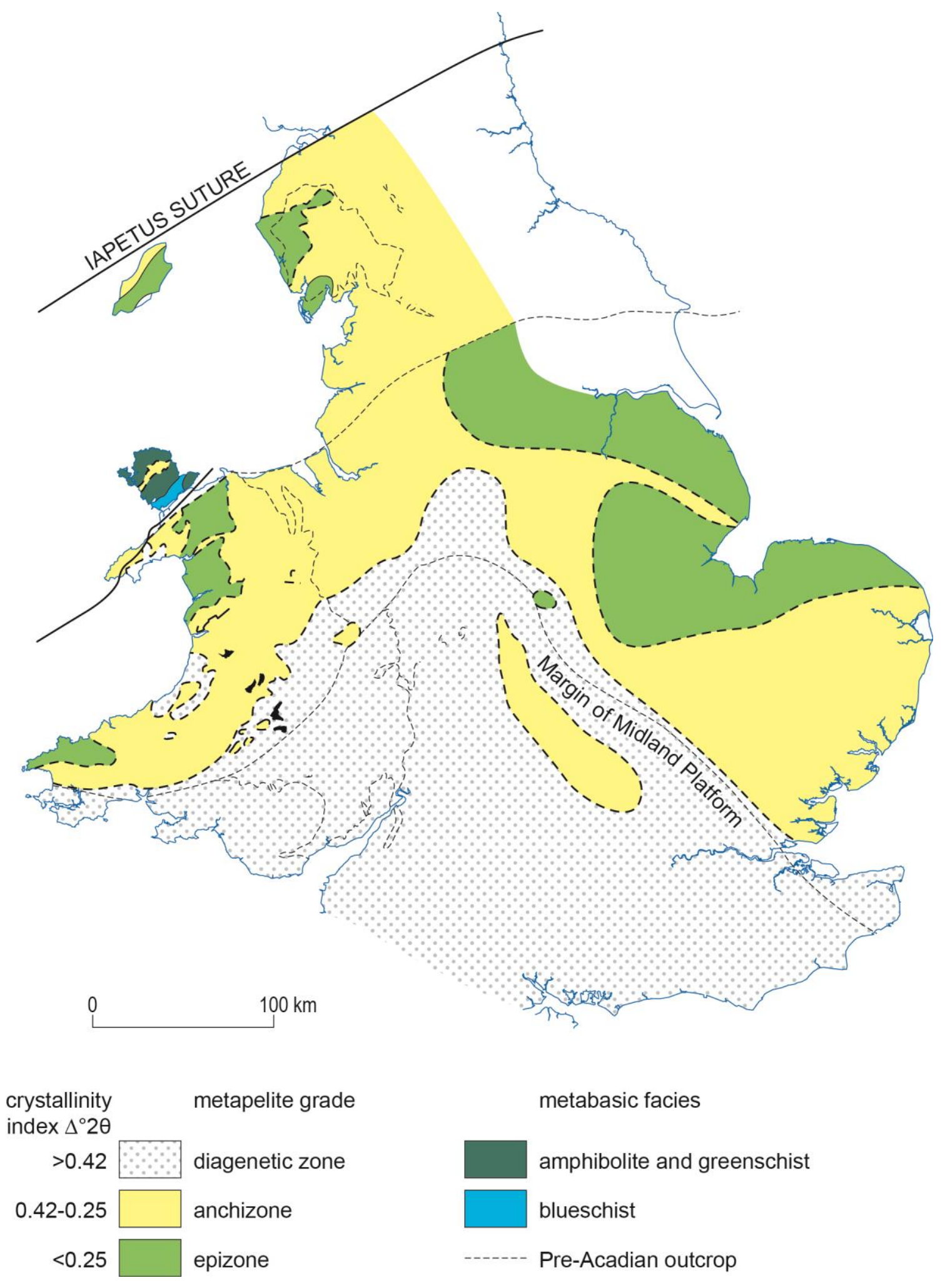

Fig. 17 


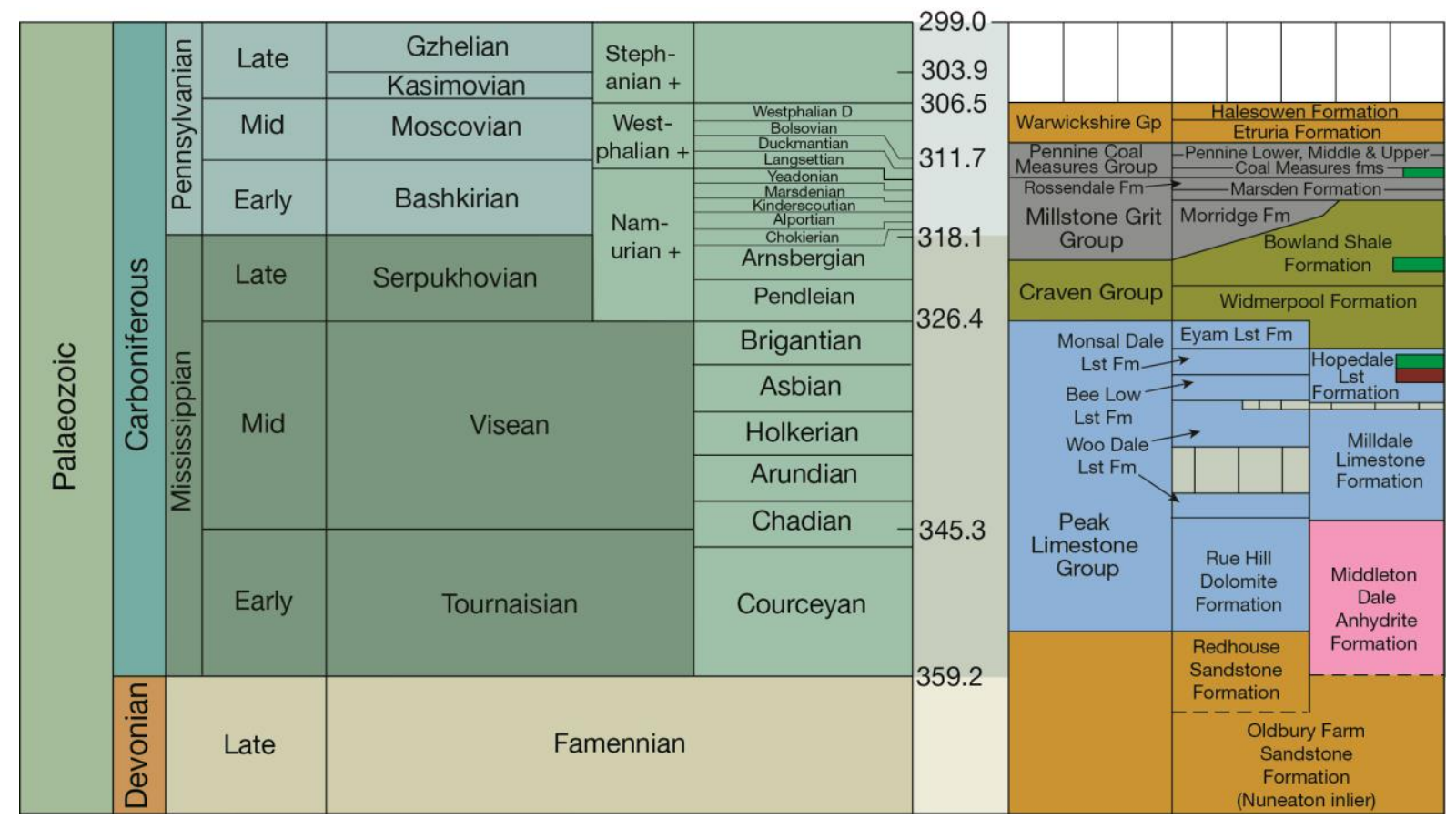

Fig. 18

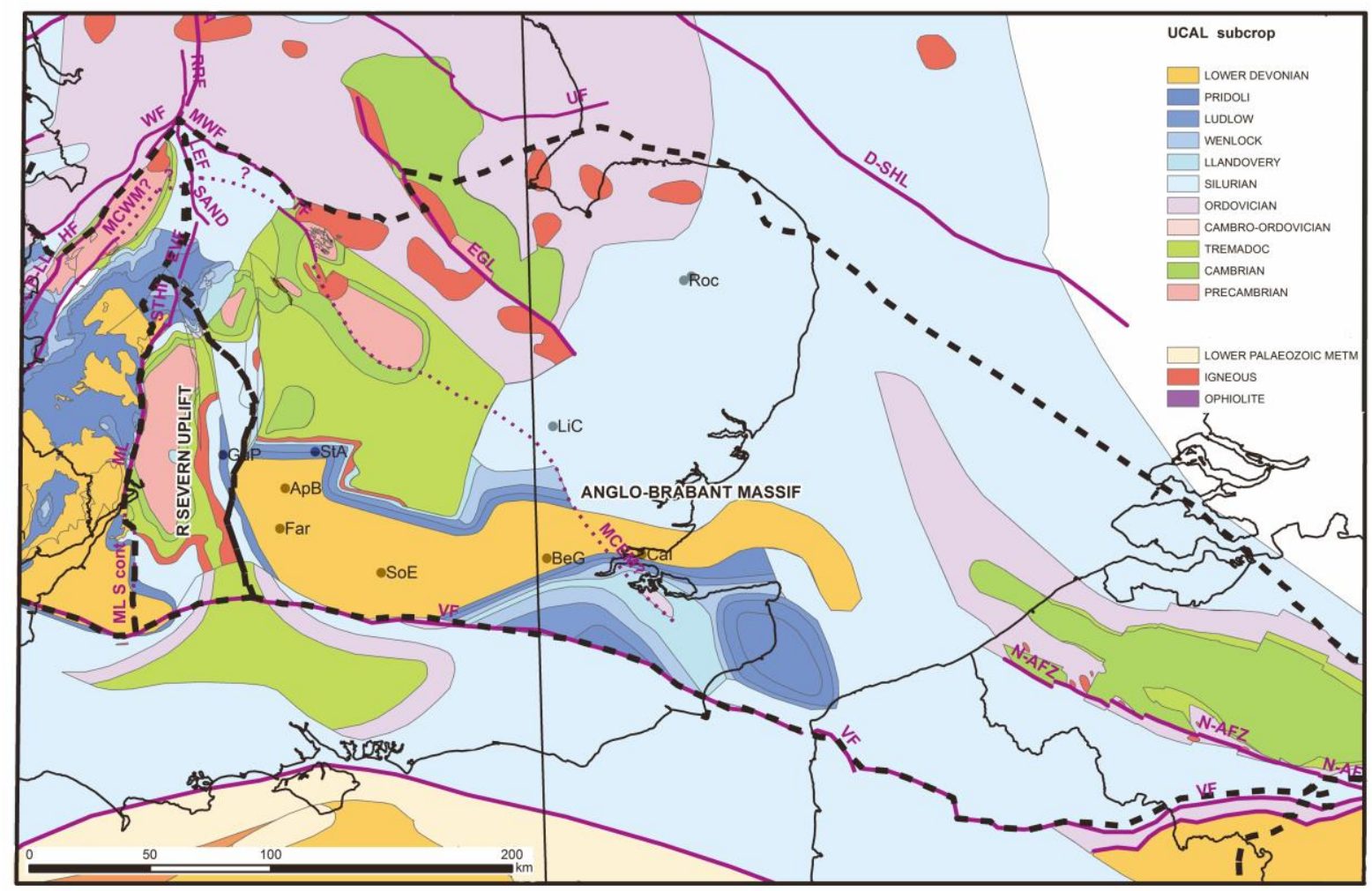

Fig. 19 


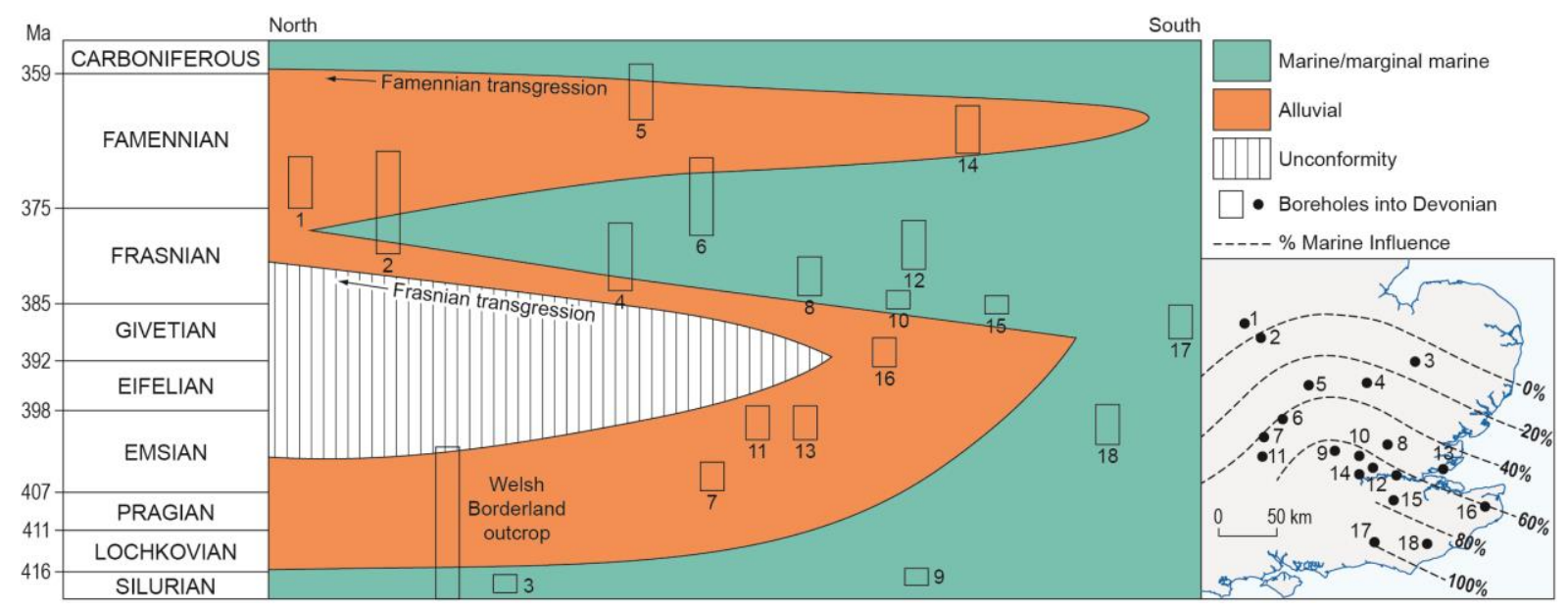

Fig. 20

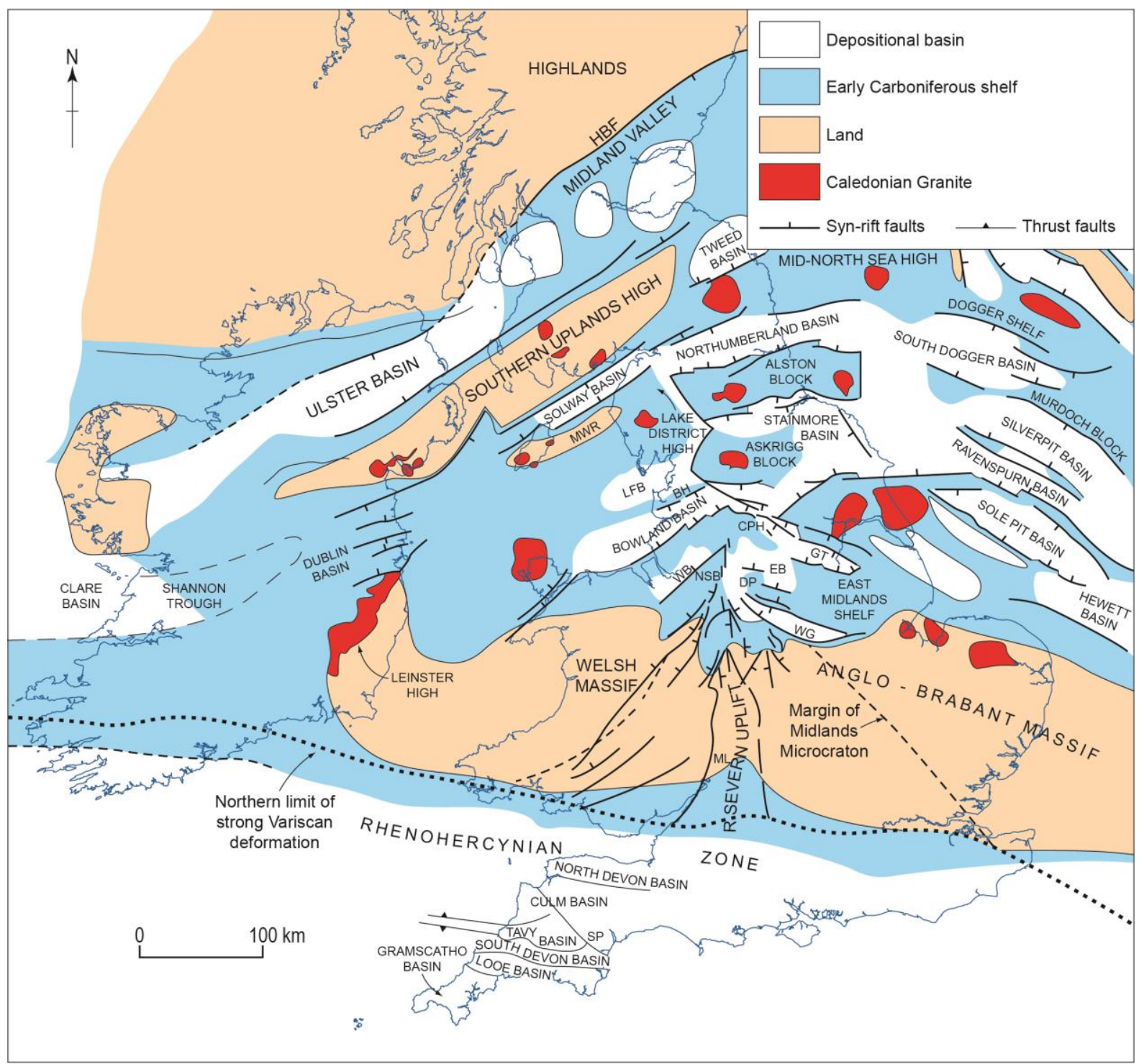

Fig. 21 


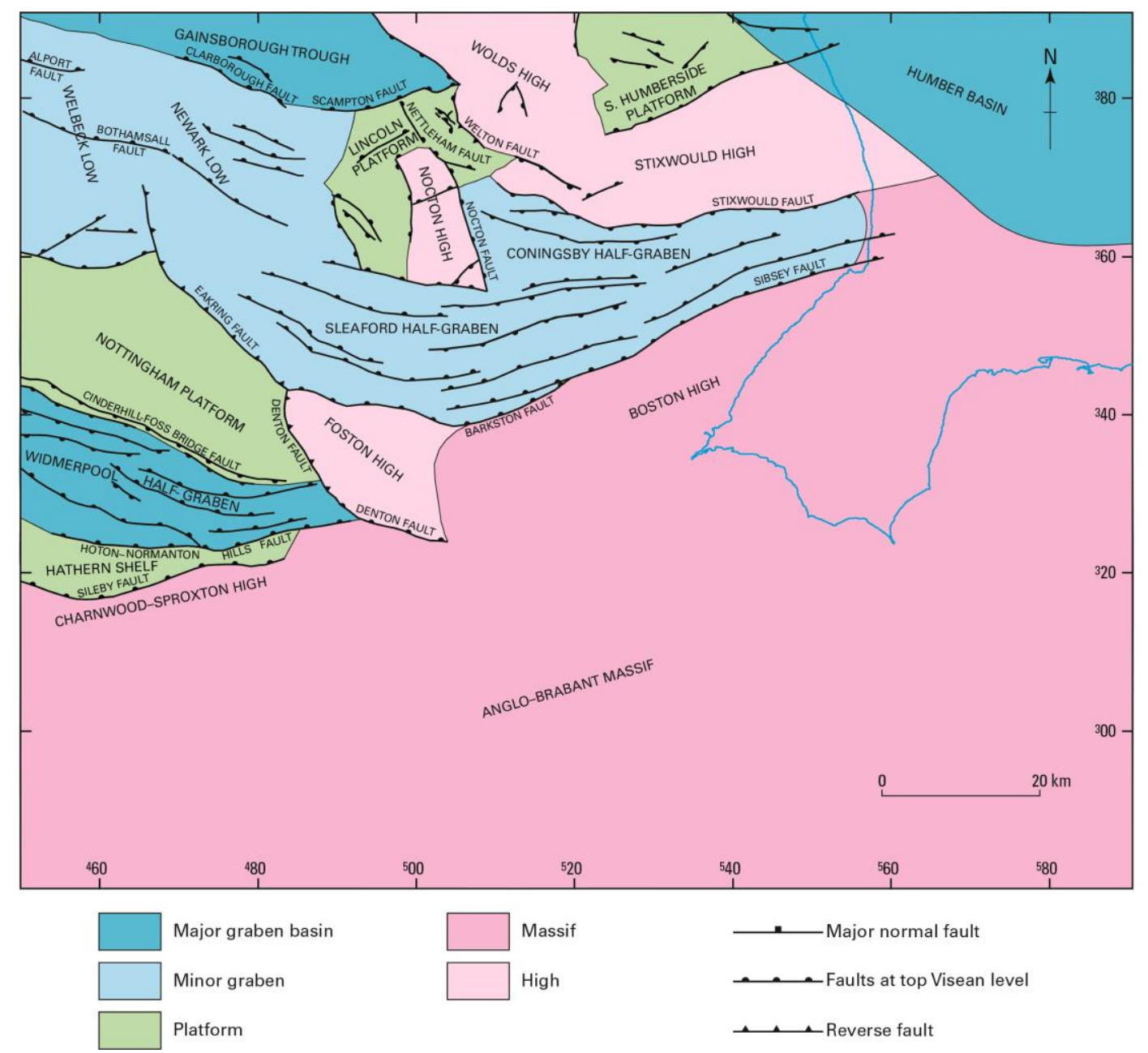

Fig. 22

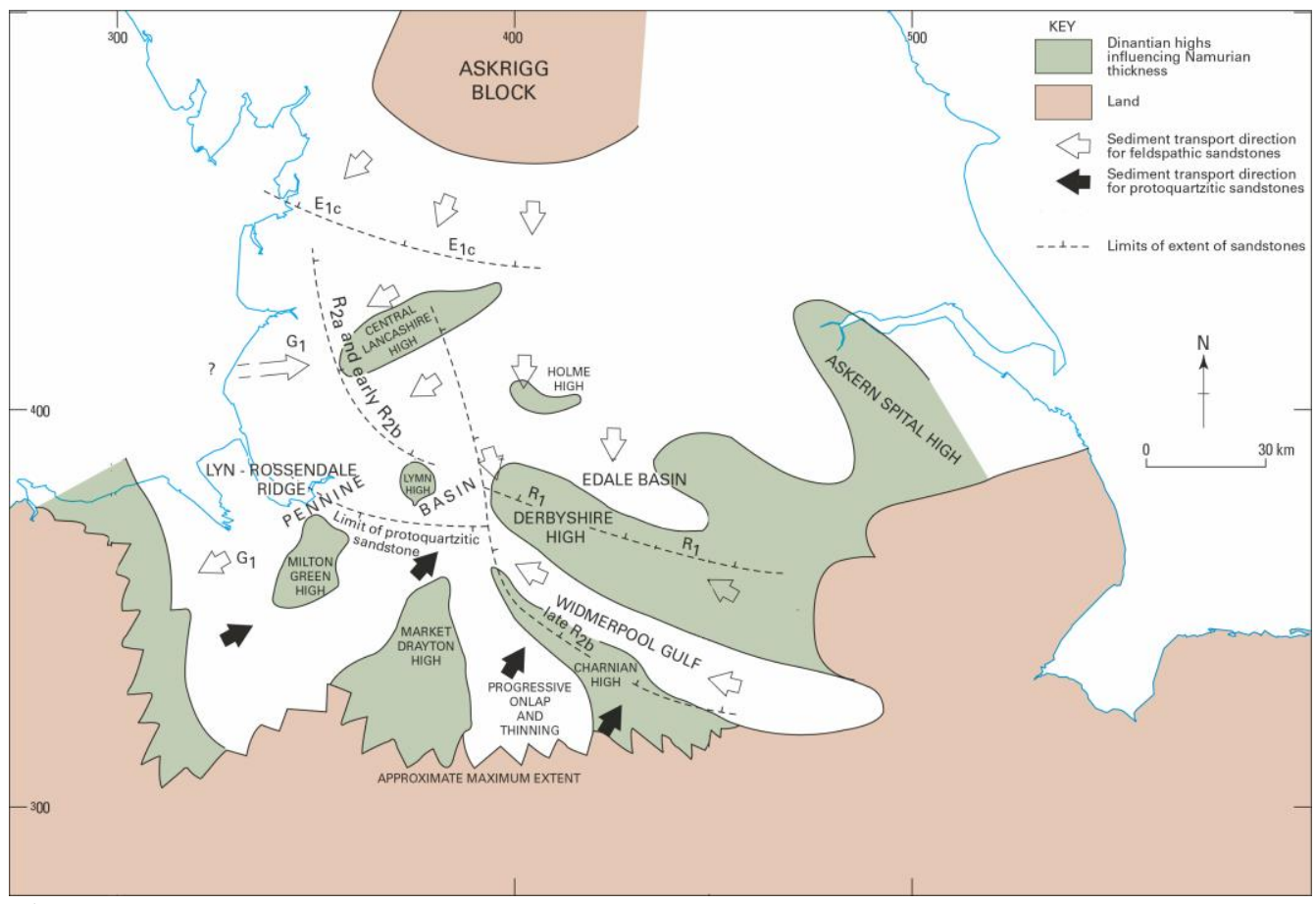

Fig. 23 


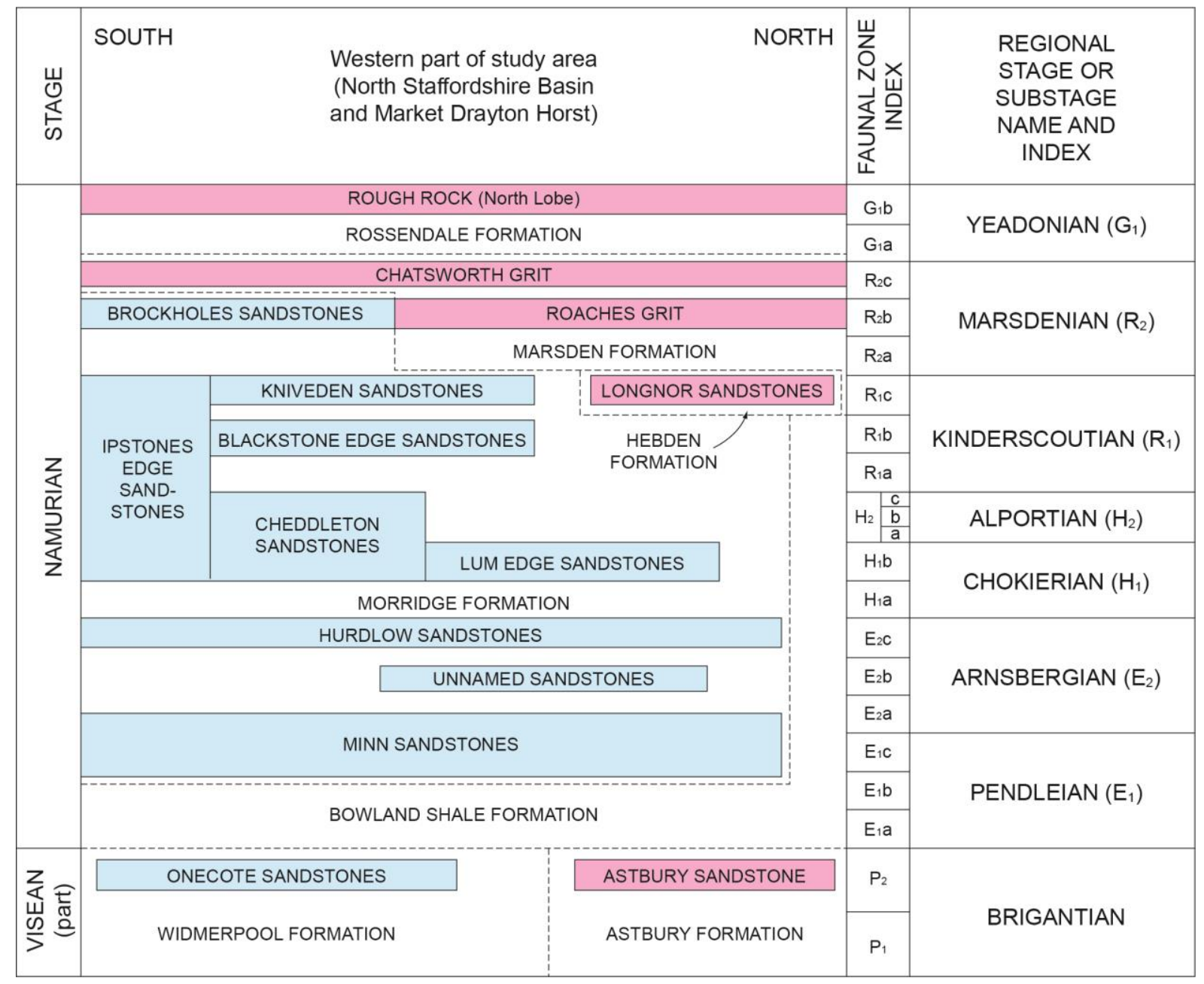

Fig. 24 

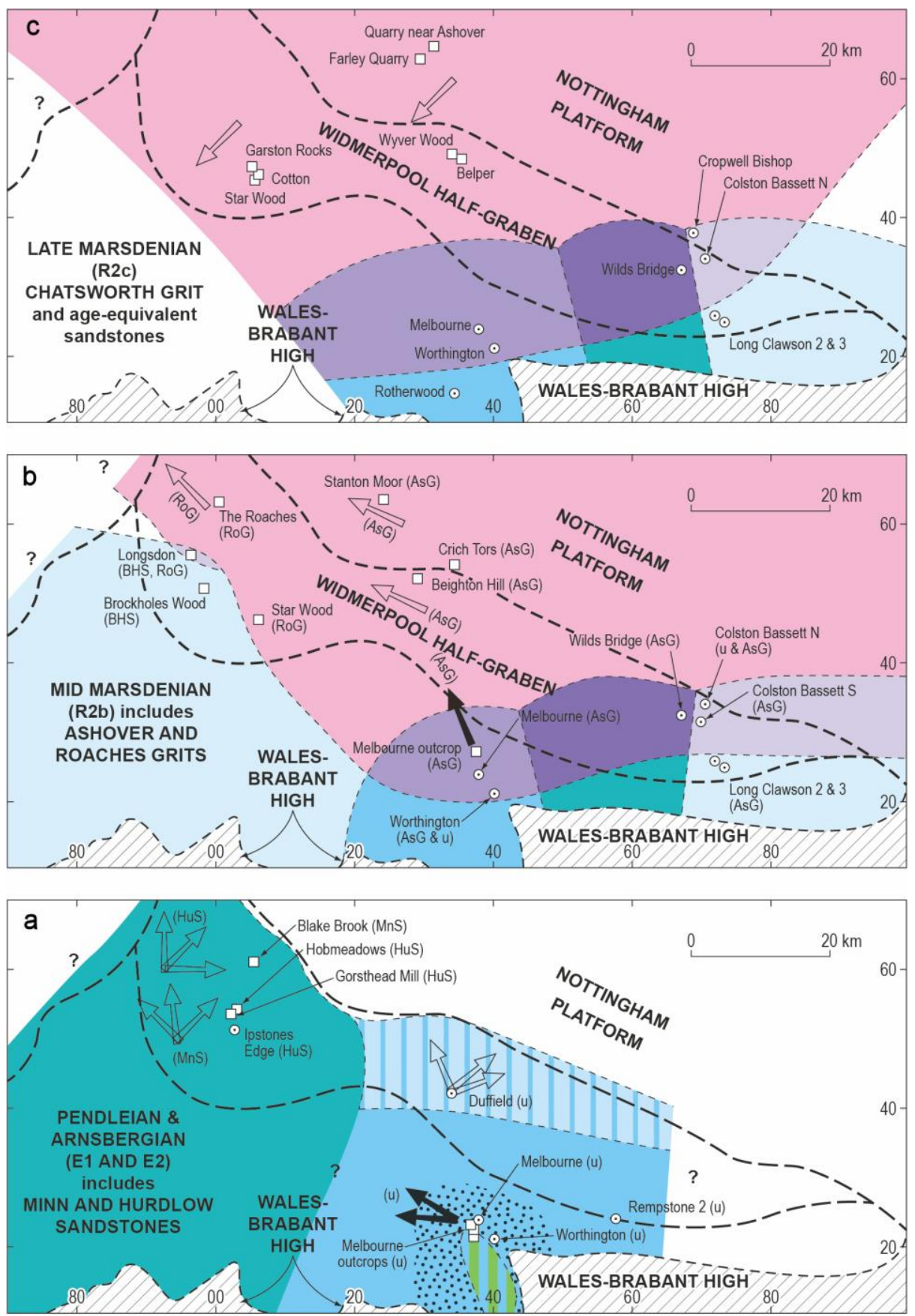

Provenance based on heavy mineral assemblages

\section{\begin{tabular}{|c} 
Northe \\
N
\end{tabular}}

Mixed northern and southern provenance

\begin{tabular}{|l|l|}
\hline $\mathrm{N}+\mathrm{S} 1$ & $\begin{array}{l}\text { Mineralogy } \\
\text { indicates that } \\
\text { individual samples } \\
\text { are of mixed } \\
\text { provenance; } \\
\text { or that samples of } \\
\text { different provenance } \\
\text { are interbedded }\end{array}$ \\
\hline $\mathrm{N}+\mathrm{S}$
\end{tabular}

(AsG) Ashover Grit

(RoG) Roaches Grit

Fig. 25

Southern provenance
\begin{tabular}{|r|r}
\hline S1 & Southern type 1 \\
\hline S1-2 & Southern type $1-2$ \\
\hline S2 & Southern type 2 \\
\hline S3 & Southern type 3 \\
\hline & S1-2 and S3 interbedded \\
\hline & A single S1-2 above many S1
\end{tabular}

(BHS) Brockholes Sandstones

(HuS) Hurdlow Sandstones $\therefore \because \because$ Feldspathic sandstones recorded

Palaeocurrent direction based on newly published data

Palaeocurrent direction based on previously published data

$\odot \quad$ Borehole sampled or mentioned in text

$\square \quad$ Outcrop sample

- - - - Generalized boundaries of named depositional areas

(MnS) Minn Sandstones

(u) unnamed sandstones 


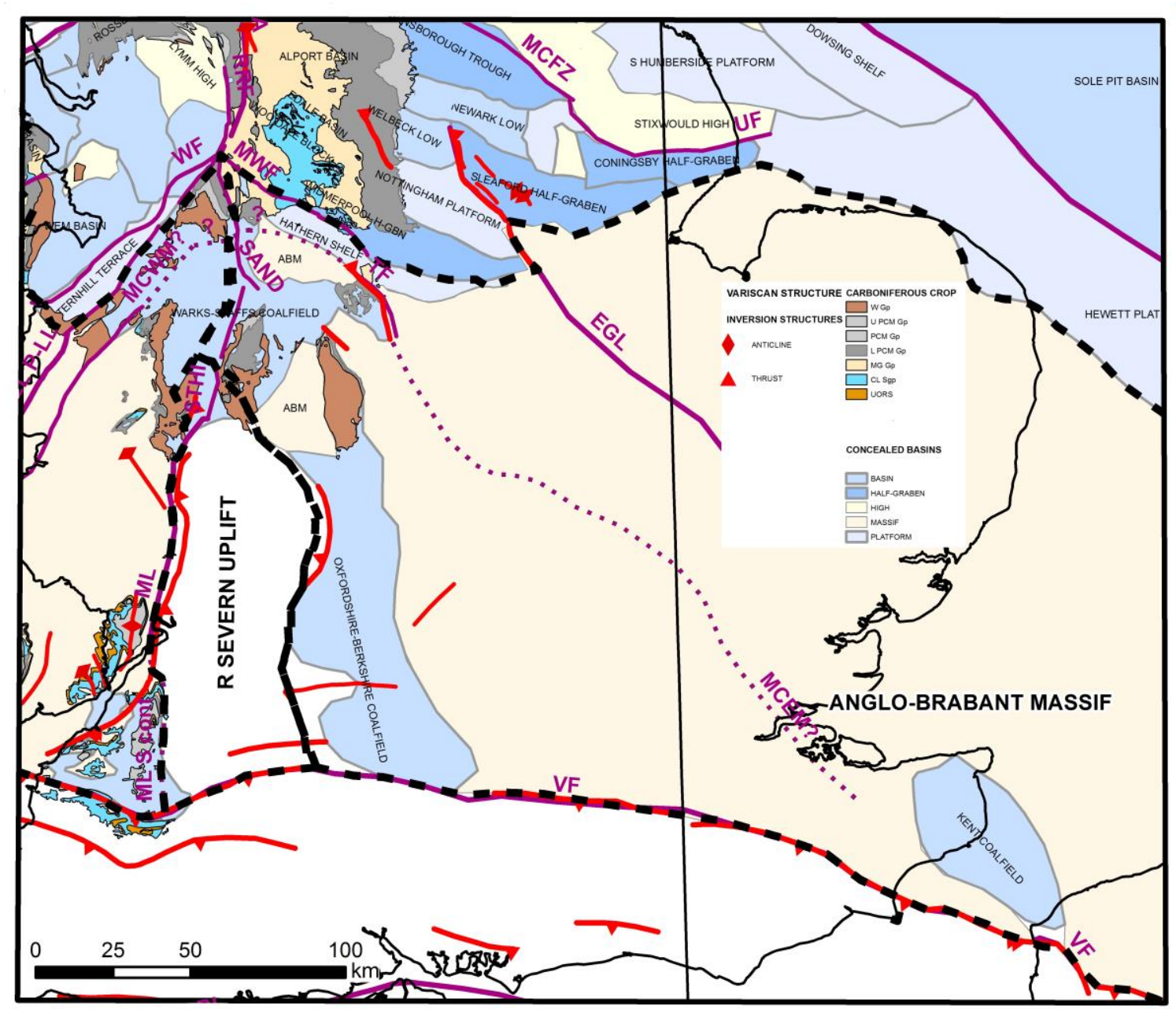

Fig. 26 




Fig. 27 


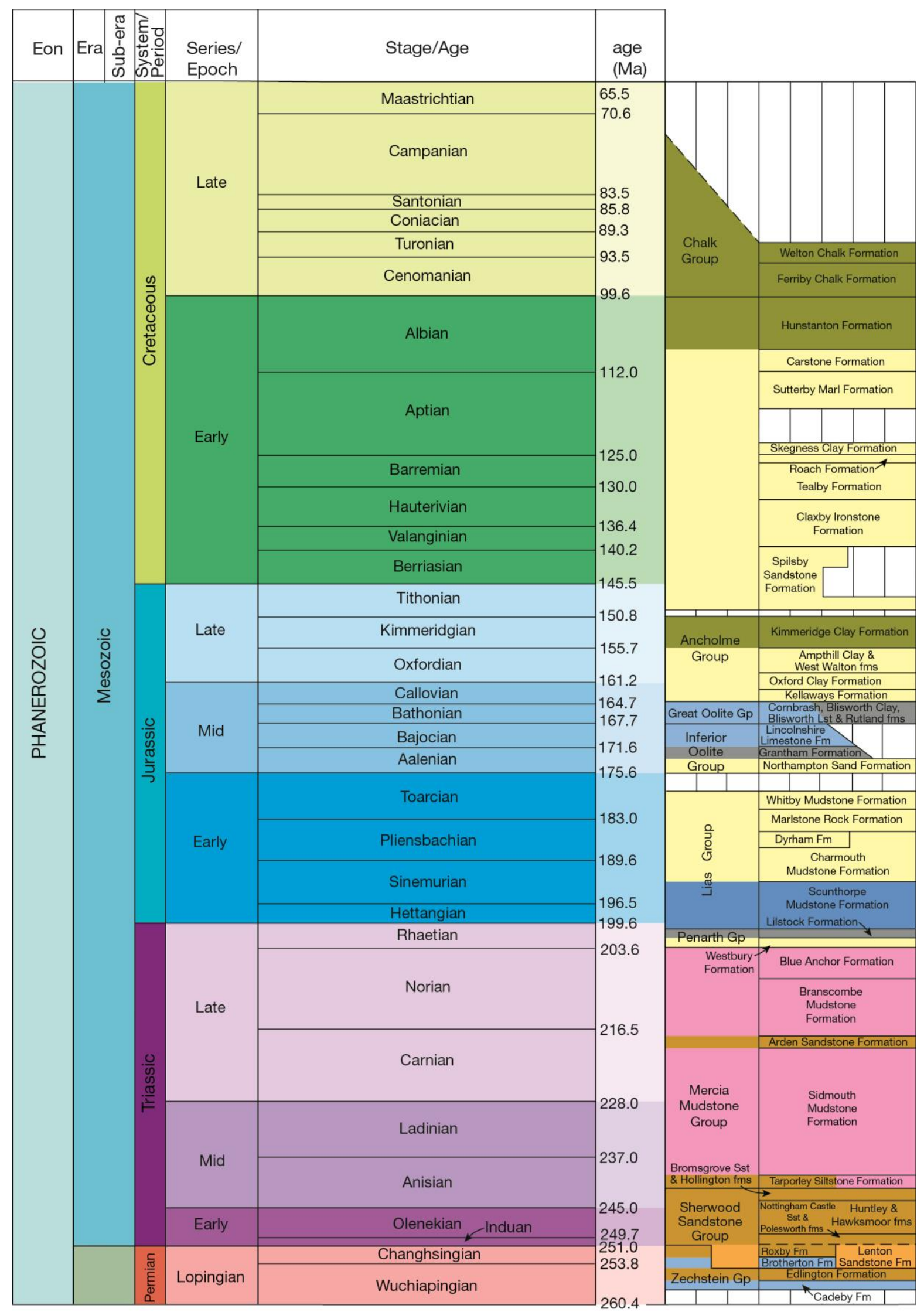

Fig. 28 


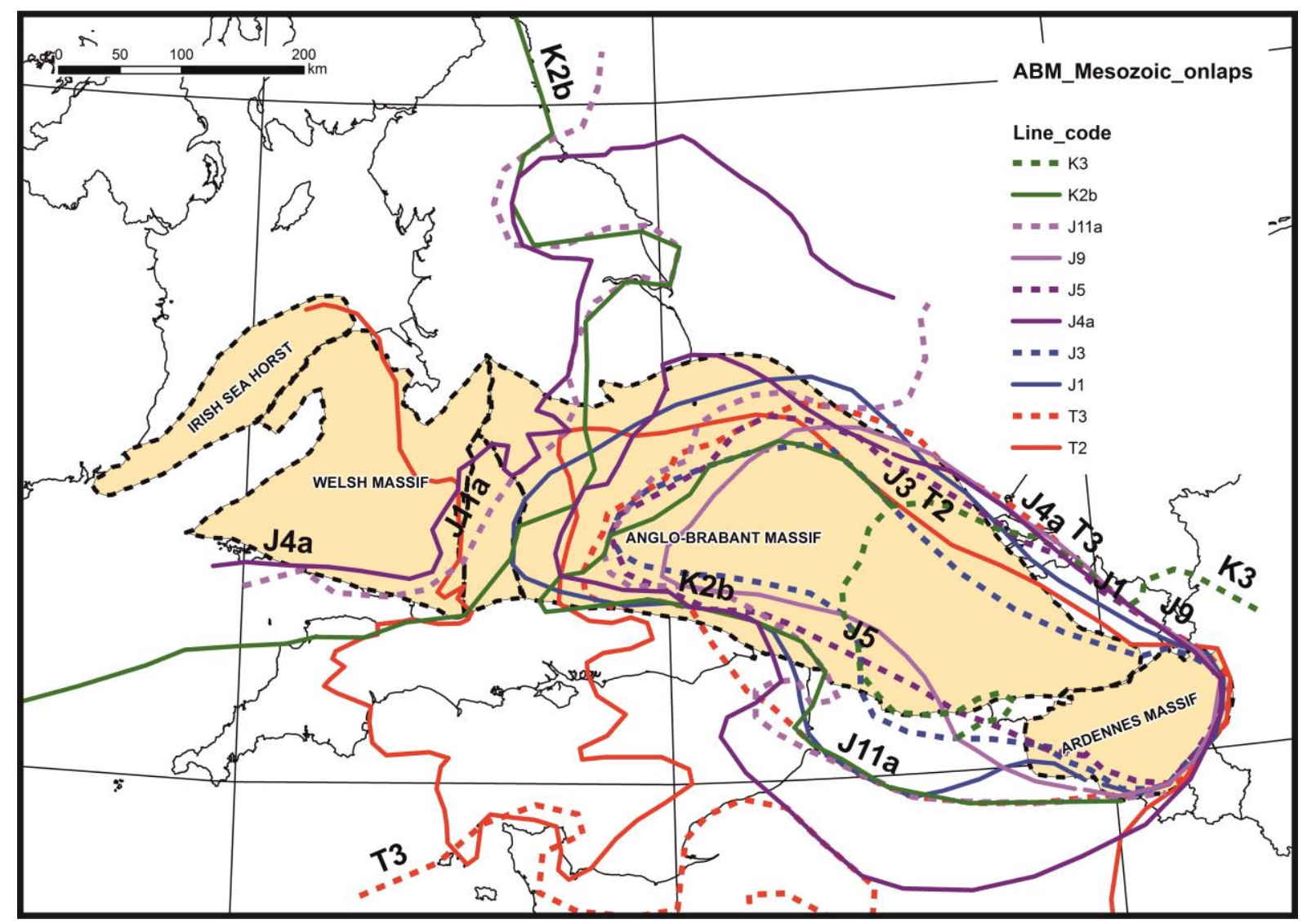

Fig. 29 


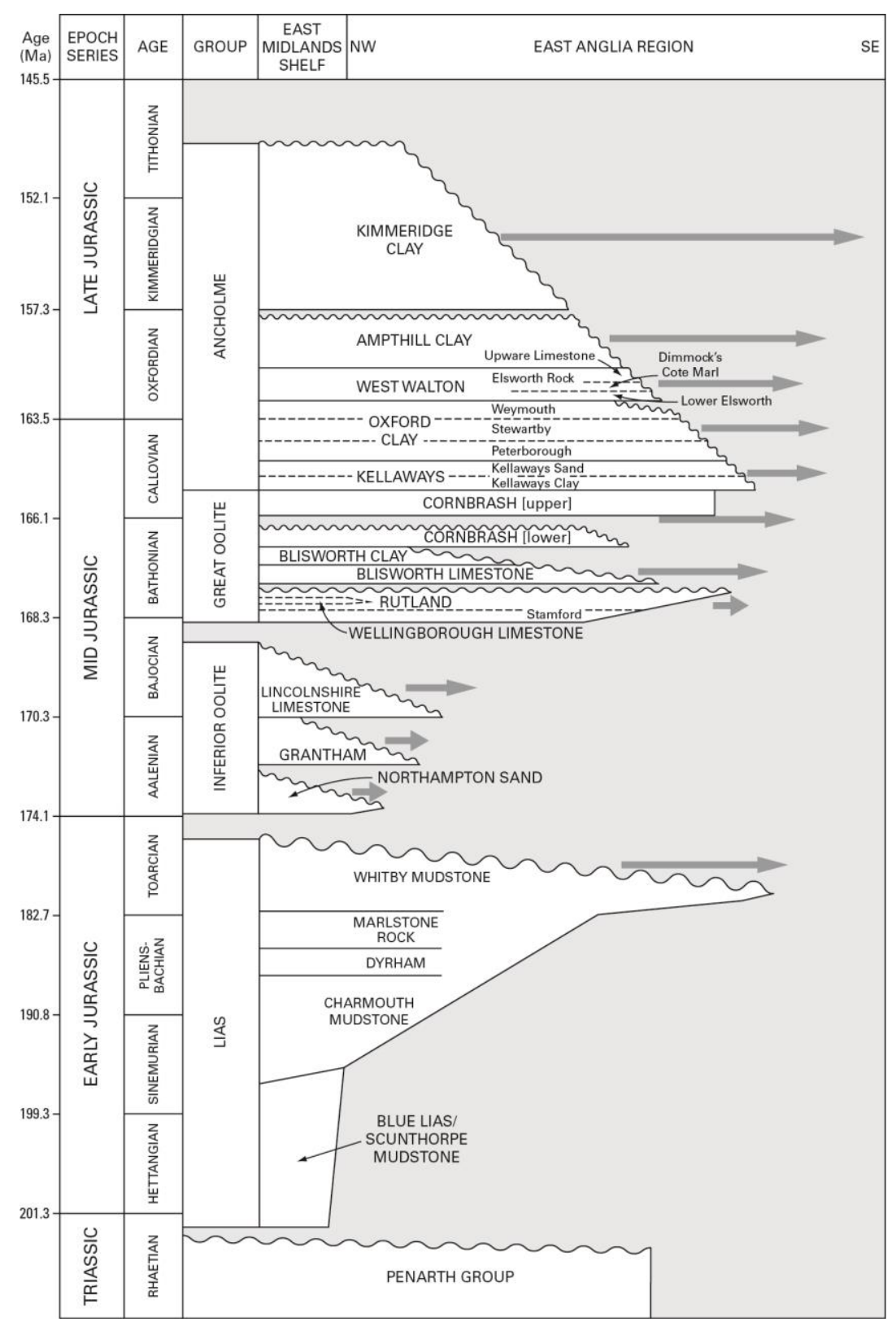

Fig. 30 


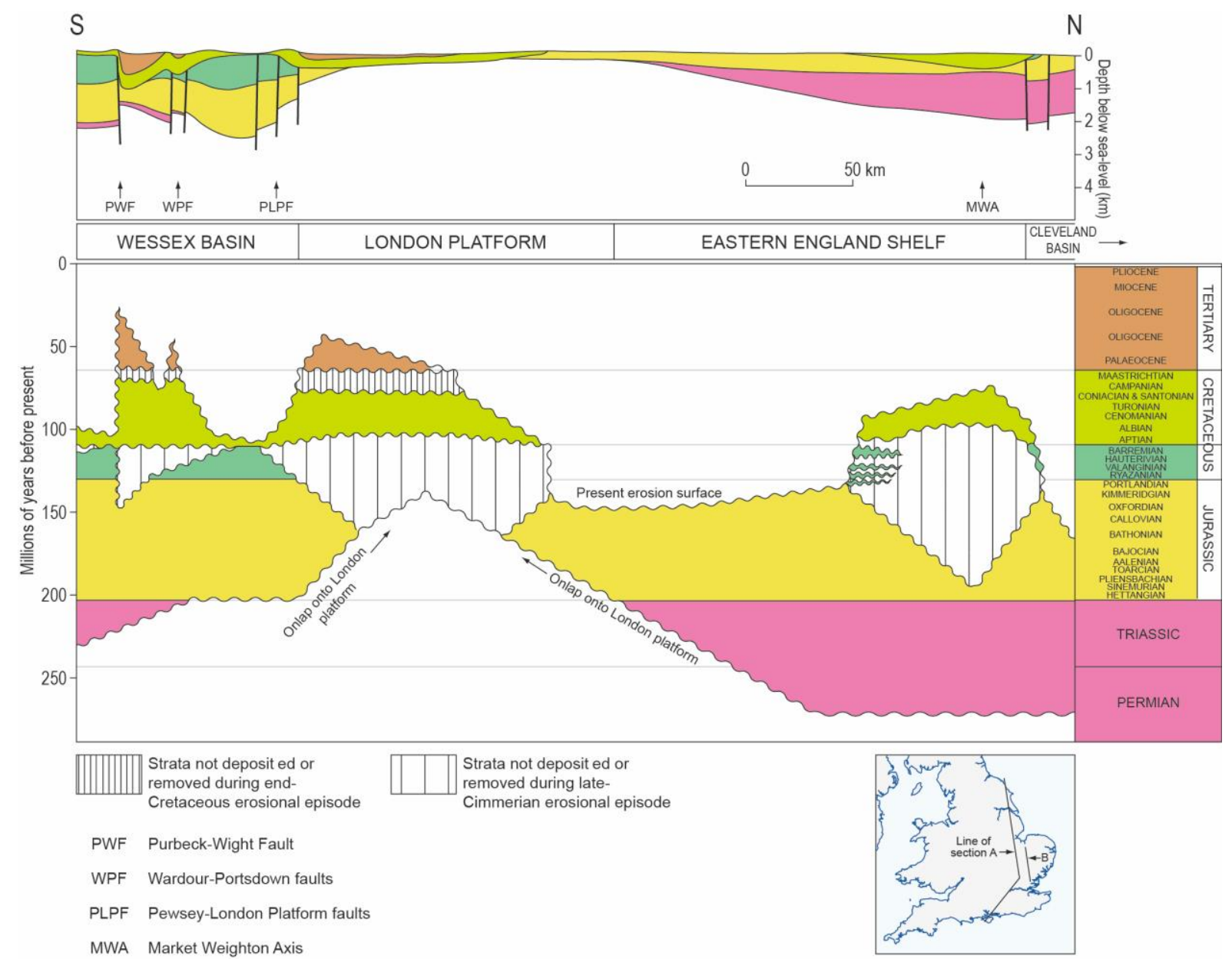

Fig. 31

N

Wiggenhal

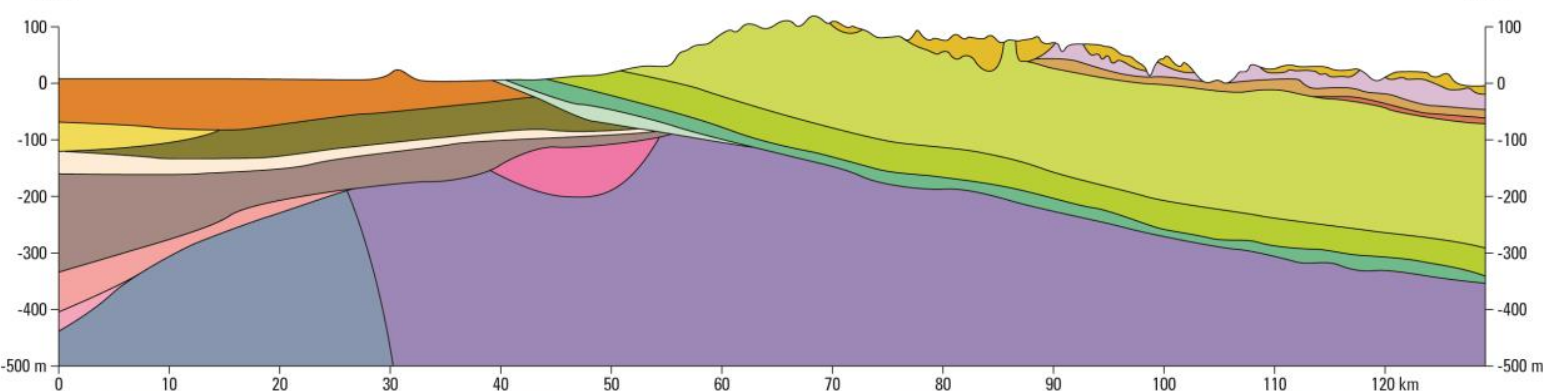

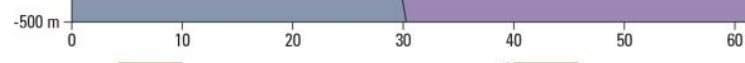

LATE NEOGENE- $\square$ Crag Group
QUATERNARY
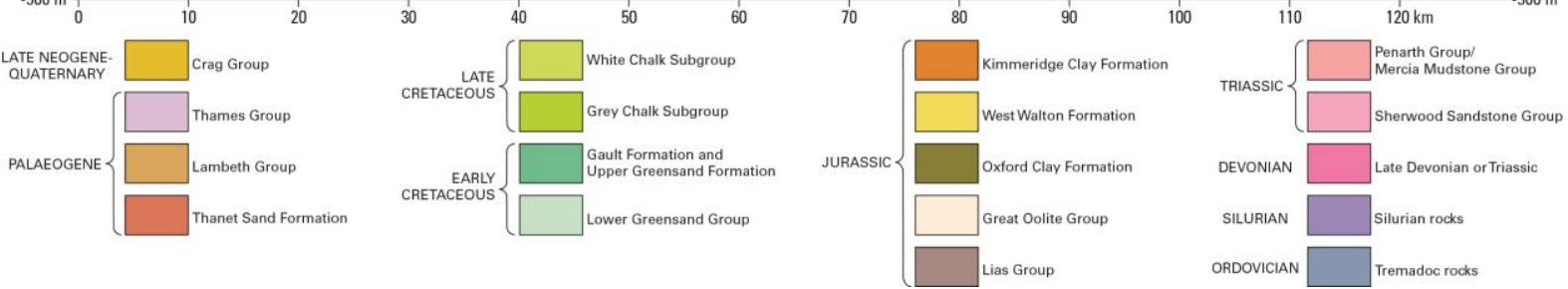

Fig. 32 